\title{
Surveys for Grassland Birds of the Malta Field Office - BLM, including a Seven-year Study in North Valley County
}

Prepared for:

USDI Bureau of Land Management

Glasgow Field Station

Prepared by:

Paul Hendricks, Susan Lenard, Coburn Currier, Bryce A. Maxell and John Carlson

Montana Natural Heritage Program a cooperative program of the Montana State Library and the University of Montana

April 2008

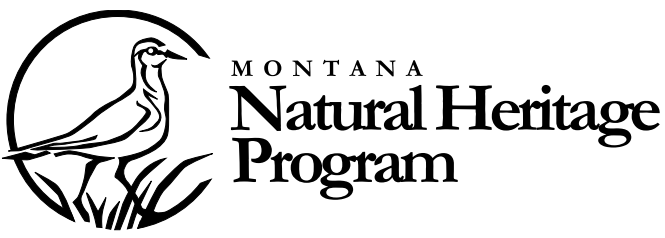





\title{
Surveys for Grassland Birds of the Malta Field Office - BLM, including a Seven-year Study in North Valley County
}

\author{
Prepared for: \\ USDI Bureau of Land Management \\ Glasgow Field Station \\ P.O. Box 871 \\ Glasgow, MT 59230
}

Agreement Number:

ESA010009, Task order \#16

Prepared by:

Paul Hendricks, Susan Lenard, Coburn Currier, Bryce A. Maxell and John Carlson

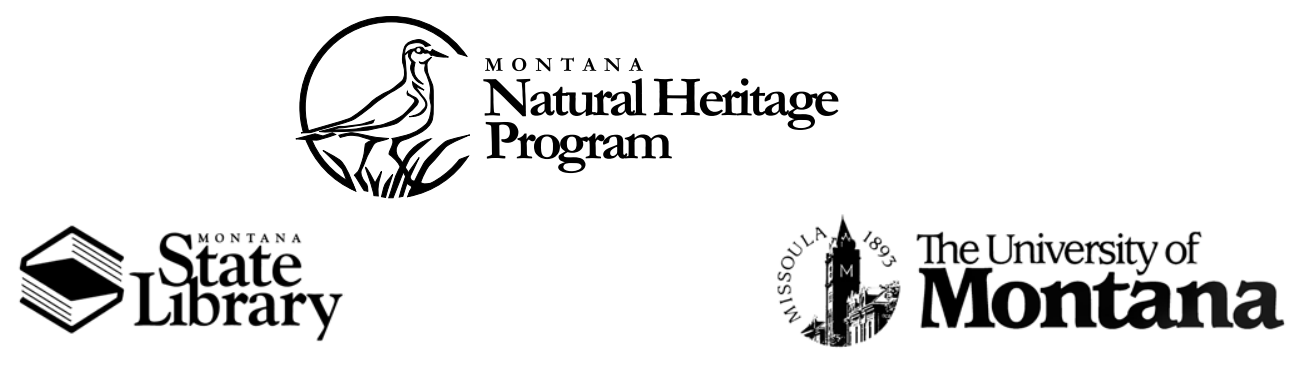

(c) 2008 Montana Natural Heritage Program

P.O. Box 201800 • 1515 East Sixth Avenue • Helena, MT 59620-1800 • 406-444-5354 
This document should be cited as follows:

Hendricks, P., S. Lenard, C. Currier, B. A. Maxell, and J. Carlson. 2008. Surveys for Grassland Birds of the Malta Field Office - BLM, including a Seven-year Study in North Valley County. Report to the Bureau of Land Management. Montana Natural Heritage Program, Helena, MT. 26 pp. plus appendices. 


\section{Executive Summary}

Grassland-associated birds have exhibited the steepest population declines of any suite of bird species in North America over the past several decades, primarily due to loss of habitat resulting from conversion of native prairie to agricultural production. To better understand the relationships of prairie vegetation structure with presence and relative abundance of native prairie bird species, fixed-radius point counts were randomly placed across BLM lands in north Valley County in areas with native grassland cover. Our objective was to gather habitat information to help guide management of grasslands for a variety of species, including a suite of grassland birds that are of conservation concern. The project evolved into a multi-year inventory (2001-2007). No other project focused on grassland birds in Montana has gathered consistent data at the same locations for this length of time.

More than 75 species of birds were recorded on 1410 point-counts (189 - 207 points each year) in north Valley County. Twenty species were recorded on at least one point count every year, nine of which are Montana Species of Concern (SOC): Long-billed Curlew (Numenius americanus), Sprague's Pipit (Anthus spragueii), Brewer's Sparrow (Spizella breweri), Lark Bunting (Calamospiza melanocorys), Grasshopper Sparrow (Ammodramus savannarum), Baird's Sparrow (Ammodramus bairdii), McCown's Longspur (Calcarius mccownii), Chestnut-collared Longspur (Calcarius ornatus), and Bobolink (Dolichonyx oryzivorous). Chestnut-collared Longspur occurred on the greatest percentage (79.7-89.9\%) of our point counts. Next in order of relative abundance were Horned Lark, Western Meadowlark, Sprague's Pipit, and Baird's Sparrow. Each of these species was detected every year on at least $30 \%$ of our count points.

The results of our seven-year study revealed considerable variation in precipitation and vegetation conditions in north Valley County that influenced where birds settled during the breeding season. For the seven years combined, Long-billed Curlew and McCown's Longspur occupied sites with shorter and less dense grasslands, while Grasshopper Sparrow, Baird's Sparrow, and Bobolink favored taller and denser grassland patches. Chestnut-collared Longspur and Sprague's Pipit occupied points with intermediate vegetation height and density near-the ground. Lark Bunting tended to occur on sites where vegetation was moderately taller but of equally low near-ground density as Long-billed Curlew and McCown's Longspur. Brewer's Sparrow was most dissimilar from the other species, occupying points with tall vegetation but relatively low near-ground density.

April-May precipitation varied among the seven years nearly five-fold, with extremes in 2002 and 2007 , respectively, and mean vegetation height and density tended to correspond accordingly. April-May precipitation accounted for $77 \%$ of variation in mean vegetation height among years on our points. Likewise, we found April and May precipitation a good predictor of the percentage of point counts on which some SOC birds would occur. Greater numbers of Baird's Sparrow, Chestnut-collared Longspur, and Bobolink tended to occur in years with greater spring precipitation, while Long-billed Curlew showed a negative response to increased spring precipitation, an expected pattern because this species selects sites with low-stature grass for nesting.

Within-year differences in vegetation structure between occupied and unoccupied points were not consistently strong across years for any species except Baird's Sparrow, which occupied points with taller and denser near-ground vegetation than was available where it was absent. Grasshopper Sparrow occupied points each year with taller or denser vegetation, but not always both. Each of the other SOC birds occupied points in some years that did not differ from unoccupied points in either measure of vegetation structure. That all of these bird species co-occurred every year, sometimes in substantial numbers and despite large differences in preferred vegetation structure, indicates that current management is maintaining a mosaic of vegetation conditions at large enough landscape scales to 
retain what appears to be a complete or nearly complete mixed-grass prairie bird community.

Surveys conducted during 2007 in nearby northern Blaine and Phillips counties found the same SOC birds in roughly the same proportions, with the exception of Baird's Sparrow, which was less abundant, and McCown's Longspur, which was more abundant (reflecting shorter and less-dense vegetation in Blaine and Phillips counties). This suggests that a large region of north-central Montana continues to support a diverse grassland bird community. To better understand the extent of this community, which has not been well surveyed, we developed predicted distribution models for 11 grassland SOC birds which should help focus surveys. Outputs from these models highlight the importance of Valley, Phillips, and Blaine Counties to the conservation of these grassland bird Species of Concern in Montana. 


\section{ACKnowledgements}

Considerable thanks and appreciation to Dave Waller, former Glasgow BLM Field Office wildlife biologist, and Roxanne Falise, former BLM State Wildlife Program Director, for recognizing the importance of this project and providing the funds to make it possible. Thanks also to Sue Crispin, Director of the Montana Natural Heritage Program, for her editorial comments on this report.

This project was supported by an agreement between the Bureau of Land Management and the Montana Natural Heritage Program (BLM AFA - ESA010009, Task order \#16). 


\section{Table of Contents}

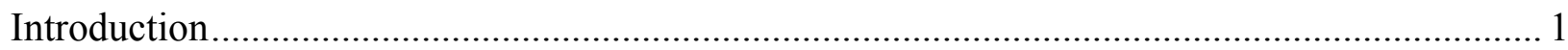

Study Area

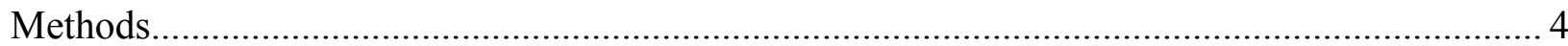

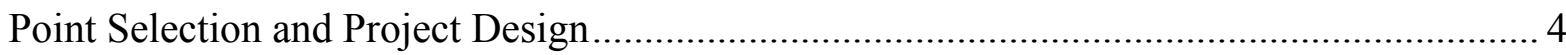

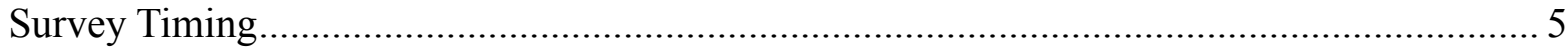

Avian Point-Count Methodology ……………………................................................ 5

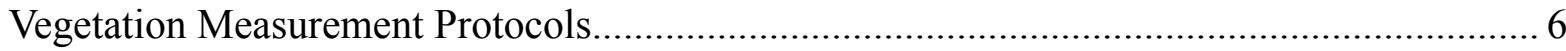

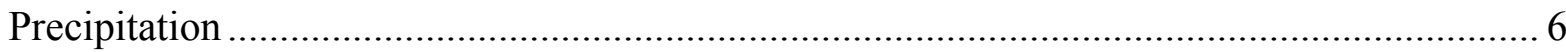

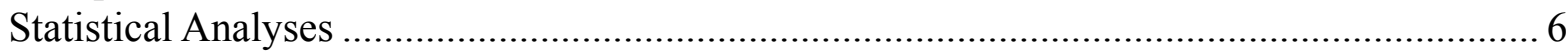

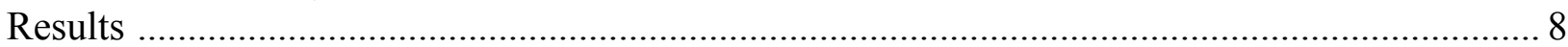

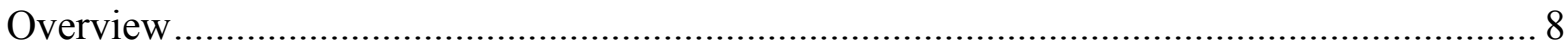

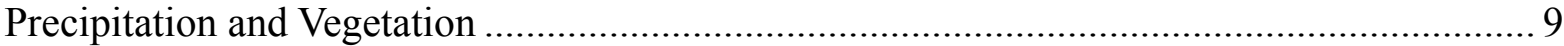

Precipitation and Annual Abundance of Species of Concern Birds......................................... 10

Vegetation Structure and Annual Abundance of Species of Concern Birds ............................ 11

Vegetation Structure and the Presence of Species of Concern Birds on Point Counts ............ 12

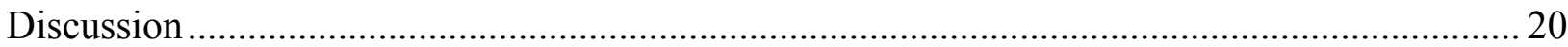

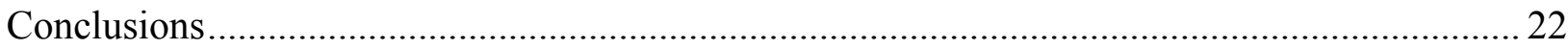

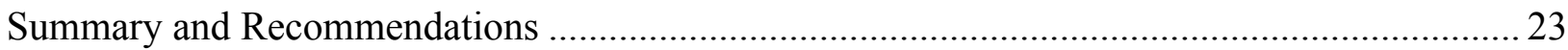

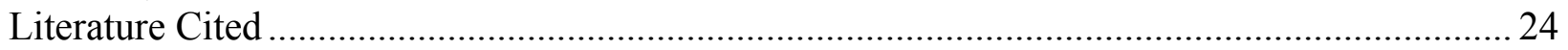

Appendix A: Global and State Rank Definitions

Appendix B: Summary of point-count surveys in northern Blaine and Phillips counties during 2007.

Appendix C: Predictive distribution models for grassland birds.

\section{List Of Figures}

Figure 1. Point count locations in the north Valley County, Montana study area .................... 3

Figure 2. Occurrence of nine Montana bird Species of Concern on point counts in north Valley County during 2001-2007................................................................. 9

Figure 3. June vegetation on three count points $(68.3,90.1,93.3)$ in north Valley

County, contrasting 2006 and 2007.

Figure 4. April-May precipitation and June vegetation height on count points, 2001-2007, in north Valley County .......................................................................... 10

Figure 5. April-May precipitation in north Valley County during 2001-2007 (Opheim station) and the relative abundance of nine Montana bird Species of Concern ....... 11

Figure 6. Ordination of nine Species of Concern birds on vegetation structure in north Valley County, Montana, based on mean values for 2001-2007 combined ............. 13

Figure 7. Vegetation height and vegetation density (number of rod contacts) for sites occupied by nine Montana bird Species of Concern in north Valley County during 2001-2007 16

Figure B1. Point count locations in northern Blaine and Phillips counties, Montana in 2007 Appendix B - 1 


\section{List OF Figures (CON'T)}

Figure B2. McCown's Longspur nests Appendix B - 4

Figure B3. June 2007 vegetation on three count points in north Phillips County Appendix B - 4

Figure C1. Composite Image of Predicted Distributions for 11 Grassland Bird Species of Concern. Appendix C - 8

Figure C2. Greater Sage-Grouse Predicted Distribution Outputs ........................ Appendix C - 9

Figure C7. Mountain Plover Predicted Distribution Outputs............................. Appendix C - 14

Figure C12. Long-billed Curlew Predicted Distribution Outputs ......................... Appendix C - 19

Figure C17. Sprague's Pipit Predicted Distribution Outputs .............................. Appendix C - 24

Figure C22. Brewer's Sparrow Predicted Distribution Outputs........................... Appendix C - 29

Figure C27. Lark Bunting Predicted Distribution Outputs .................................. Appendix C - 34

Figure C32. Grasshopper Sparrow Predicted Distribution Outputs ..................... Appendix C - 39

Figure C37. Baird's Sparrow Predicted Distribution Outputs.............................. Appendix C - 44

Figure C42. McCown's Longspur Predicted Distribution Outputs ...................... Appendix C - 49

Figure C47. Chestnut-collared Longspur Predicted Distribution Outputs ........... Appendix C - 54

Figure C52. Bobolink Predicted Distribution Outputs ........................................ Appendix C - 59

\section{LIST OF TABLES}

Table 1. Summary of observers, number of transects, and number of point counts

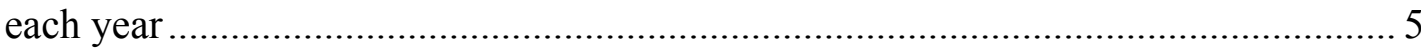

Table 2. Bird species of conservation interest occurring on point counts in north Valley County during 2001-2007 ......................................................................... 7

Table 3. Bird species detected every year (2001-2007) within north Valley County, Montana point-count circles ................................................................................. 8

Table 4. April and May precipitation $(\mathrm{cm})$ measured at the Opheim station (OPMM8), north Valley County .............................................................................................. 9

Table 5. Descriptive statistics (mean [SD]) for vegetation measurements at North Valley County point counts, 2001-2007 …………………................................... 9

Table 6. Spearman correlations between percent occurrence on point counts for nine SOC birds and vegetation height and vegetation density index (contacts), 2001-2007 12

Table 7. Vegetation height and vegetation density index (contacts) comparing points where nine SOC birds were detected and not detected, 2001-2007. 12

Table 8. Mean vegetation height and near-ground vegetation density (contacts 0-1 dm) for points occupied by nine Montana SOC birds ...................................................... 14

Table 9. Mean vegetation height and density index (contacts $0-1 \mathrm{dm}$ ) comparisons for points where nine Montana SOC birds were detected and not detected 19

Table B1. Bird species detected on point counts in north Blaine and Phillips counties in June 2007 Appendix B - 3 


\section{List OF TABLEs (CON'T)}

Table B2. Comparison of the relative abundances (percent of point counts) for eight Montana Species of Concern birds in north Blaine and Phillips counties and north Valley County that were detected on point counts in 2007

Appendix B - 3

Table C1. Overview of Bird Observations Used in Modeling Effort.................... Appendix C - 3 


\section{INTRODUCTION}

In recent decades, grassland bird populations have exhibited range-wide declines (Knopf 1994, Peterjohn and Sauer 1999, Vickery et al. 1999, Askins et al. 2007). Historical conversion of the landscape to agricultural cropland is clearly the greatest contributing factor to loss of suitable habitat (Samson and Knopf 1994, Fitzgerald et al. 1999, Knapp et al. 1999, Blann 2006). Habitat loss resulting from fragmentation and conversion for agricultural, industrial, and human habitation uses continues, contributing further to grassland bird population declines. Additionally, a variety of land management practices in areas of remaining intact prairie can negatively impact prairie bird populations (Saab et al. 1995). Worldwide, grasslands are recognized as the most imperiled of terrestrial landscapes (Samson and Knopf 1996).

Individual grassland bird species choose where to settle for breeding and nesting from a matrix of habitats available across the prairie landscape. Historically, each species probably exhibited pronounced fluctuations in local abundance as vegetation conditions changed in response to drought, fire, and grazing by bison and locust. The extermination of bison, the extinction of Rocky Mountain locust, and aggressive control of fire during the settlement of the Great Plains profoundly altered the composition of grasslands (Knapp et al. 1999). Grassland associated species favoring vegetation structure and composition promoted by human activities (managed grazing, fire suppression, and annual mowing) have generally benefited, while species requiring a more natural disturbance regime (periodic fire and historic grazing patterns) have generally experienced declines (Sauer et al. 2005). Because of the widespread loss of native grasslands, remaining tracts of prairie grassland vegetation are increasingly valuable for native bird species.
Understanding how grassland birds respond to different vegetation conditions can contribute to the range-wide conservation of prairie bird species, because this permits managers to manipulate vegetation in ways that can promote or inhibit settlement and nesting. Unlike other areas in the Northern Great Plains, populations of many native grassland bird species have been relatively stable in northeastern Montana over the last 40 years (Sauer et al. 2005). Thus, north Valley County is ideal for understanding the ways in which a suite of grassland birds responds to "natural" variation in grassland conditions, because it appears the impacts of livestock grazing on vegetation structure of public rangelands throughout much of the region are relatively minor.

The purpose of this report is to provide a summary of project activities during 2001 - 2007, supplementing Lenard et al. (2006) and Hendricks et al. (2007). In this report we 1) identify the regular grassland-breeding bird community in north Valley County (revised from earlier reports), 2) provide an assessment of the status of a suite of Montana bird Species of Concern (SOC) that are members of this community, 3 ) identify the role spring precipitation plays in fluctuations of these species through its effects on vegetation structure, and 4) describe the range of vegetation conditions where each species settled during the nesting period. In addition, we provide the results of a one-year survey of grassland birds conducted in adjacent northern Blaine and Phillips counties (on lands administered by the Malta Field Office-BLM) in 2007 and contrast these with results of the north Valley County project. Finally, we present and discuss predicted distribution models for the nine grassland SOC birds we discuss more fully in this report. We anticipate these models will be useful for guiding future survey and monitoring efforts. 


\section{Study Area}

Located on the Northern Glaciated Plains, the study area lies in the northern half of Valley County in northeastern Montana (Figure 1). The county lies adjacent to the border with Saskatchewan, Canada and is bounded by the Missouri River to the south, Phillips County to the west and Daniels and Roosevelt Counties to the east. The project area includes BLM lands north of Glasgow, east of Opheim and west of Valleytown, in an area roughly $45 \times 30$ miles (1350 square miles). Bitter Creek, Frenchman Creek, Crow Creek, Rock Creek, Willow Creek, and Buggy Creek, all located generally within the project boundaries, drain to the Milk River. The Bitter Creek Wilderness Study Area, nearly 60,000 acres of highly eroded badlands recognized for its unique, isolated and unspoiled nature, is situated approximately at the project center. To the east and adjacent to the project area is Dry Fork Creek, primarily contained within a large block of Montana Department of Natural Resources Conservation lands. Cooper et al. (2001) describe this area as possibly the best intact site of a rare mid-grass prairie (northern porcupine grass-thickspike wheatgrass) remaining in the United States.

The physical characteristics of this area are similar to the surrounding lands. Glacial till and outwash cover the terrain as the area's gently rolling landscape was scoured by at least two glacial events. The most common substrate in the project area is clay shale, marine in origin and dark grey in color (Cooper et al. 2001). The local climate is considered semi-arid with precipitation of approximately 10-14 inches (25.4-35.6 cm) per year, much of it falling as early summer rains in late May and early June. Winters are generally frigid while the summers can be hot, punctuated by hail-producing thunderstorms that can result in flash floods. The greatest topographic variation in the county occurs at its eastern half; the highest elevation of approximately 3,300 feet (1006 m) occurs near Opheim to the north, while the lowest elevation of approximately 2,000 feet $(610 \mathrm{~m})$ occurs where the Missouri River leaves the county to the south. Specific point locations on the project ranged from 2,448-3,049 feet (746-930 $\mathrm{m}$ ) in elevation. While the primary landcover within the project boundary is native mixed-grass prairie, the majority of the surrounding land has been cropped for agricultural production. This area is significant as it encompasses the most extensive remaining piece of intact prairie land in Montana. For a more detailed description of vegetative communities and distinguishing attributes specific to the study area see Cooper et al. (2001). 


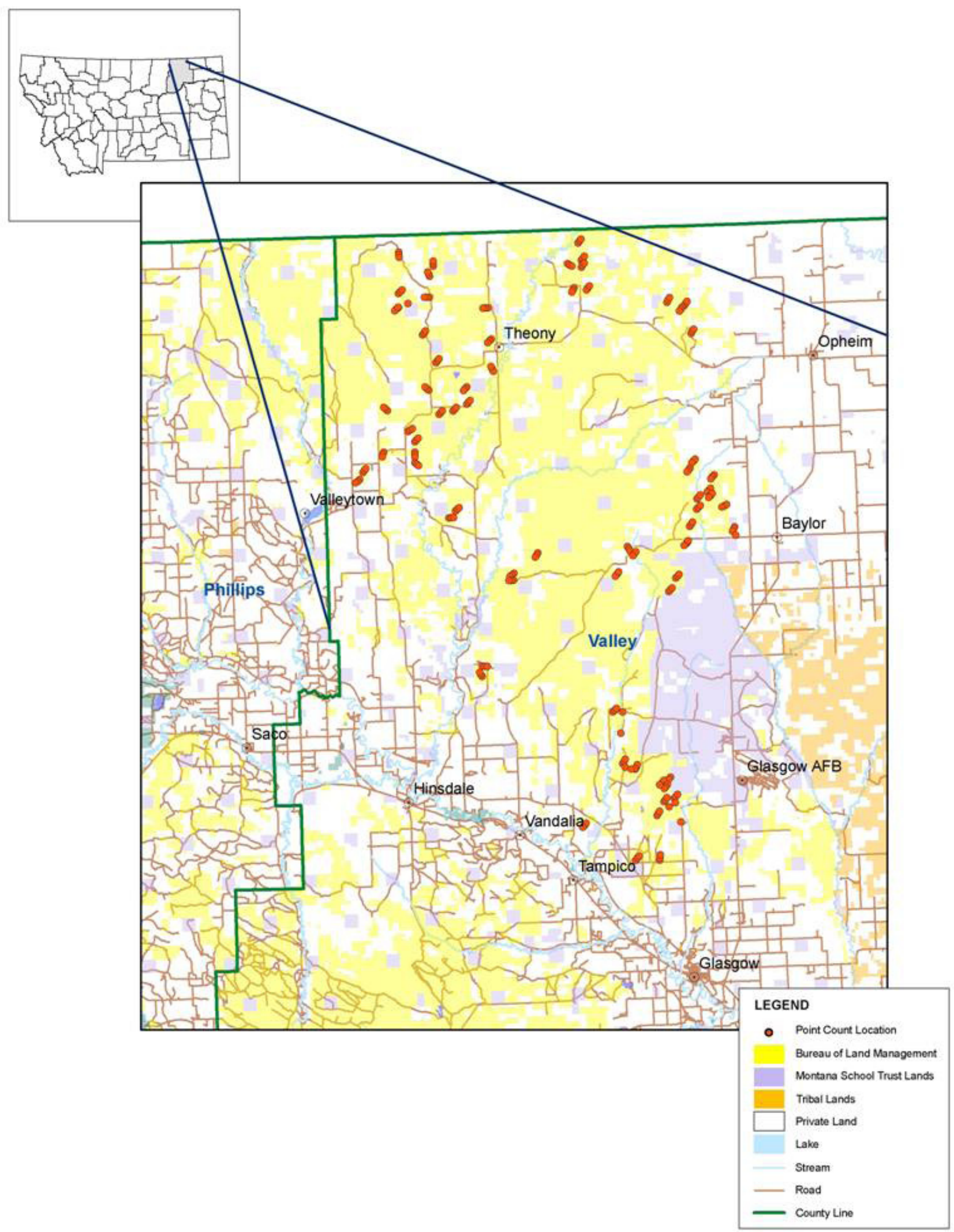

Figure 1. Point count locations in the north Valley County, Montana study area. 


\section{Methods}

\section{Point Selection and Project Design}

The long-term project (2001-2007) focused on BLM lands in north Valley County, supplemented by similar work in northern Blaine and Phillips counties in 2007. Initial steps for identifying where to sample for birds involved using a Geographic Information System (GIS) to stratify the area under consideration by soil type using the University of Montana Satellite Image Land Cover Classification (SILC) soil data. Areas classified as having silty soils, those that support growth of native grass species important to grassland birds, were used to delineate the area within which inferences were to be made (i.e., the target population). Areas classified as high clay content soils were eliminated from survey, because the vegetation associated with clay soils does not generally support a broad diversity of grassland birds. Eliminating highclay soils effectively eliminated the badlands area surrounding Bitter Creek located at the center of the study area. However, some areas on the western portion of the project ended up being located in areas with high-clay soil.

Within the area targeted for sampling, 120 bird survey point locations were randomly generated from which we originated transects for the project. Originally, each point-count transect was to consist of four points. However, since the original point locations were random, it would have been difficult, if not impossible, to generate a line of four points within one pasture (generally a quarter-section) given the 300 meter minimal distance required between points for standard point-count protocol (Hutto et al. 1986, Drapeau et al. 1999). Thus, the scope of the project was changed to accommodate transect lines consisting of three points. After locating the randomlygenerated point on the ground via a GPS unit, the second and third points were identified by field personnel walking no less than 300 meters from each previous point, resulting in a total straight line transect length of approximately 600 meters. Each of the three points defined the spot at which each point-count survey was conducted. Coordinates for all points were recorded on GPS units for finding survey locations in subsequent years. The second and third points in each transect were generally established to the northeast if there was room to do so and remain in the same pasture as the original point. If this was not the case, then the points were oriented to the southwest of the original point. Efforts were made to keep all three points within the same pasture/grazing treatment. This sometimes necessitated placing the second and third points on opposite sides of the first point (one to the northeast and one to the southwest). If a northeast-southwest placement was not possible, then a northwest-southeast orientation was followed, in whichever direction allowed the points to be contained within one pasture. Inadvertently, and due to time constraints at the start of the project, nine transects ended up with points not wholly contained within one pasture. One transect includes one point-count circle entirely in a different pasture; 7 transects include all center points in the same pasture, but one of the $100 \mathrm{~m}$ radius point-count circles overlapping an adjacent pasture; and 2 transects include one point with the center in an adjacent pasture but a portion of the $100 \mathrm{~m}$ point-count circle within the first pasture.

During the first field season (2001) the points were divided among two field personnel such that points west of the Willow Creek/Bitter Creek area were assigned to one observer while those on the east were assigned to the second observer. The points ultimately surveyed were selected across each region based upon accessibility and distribution. Points were generally considered accessible if they could be reached by vehicle (on existing two-tracks) to within a walking distance of approximately one mile. Effort was also made to survey both the eastern and western points such that the maximum north-south distribution was accomplished. Field personnel attempted to maximize the number of point counts conducted in a day; 3 - 4 transects ( 9 - 12 points) were targeted each morning.

Point counts were conducted by Paul Hendricks and John Carlson during the first three years 
(2001-2003) of survey (Table 1). In 2004, the point counts were conducted by four individuals: Paul Hendricks, John Carlson, Susan Lenard, and Coburn Currier. In 2005 - 2007, Hendricks, Lenard, and Currier conducted the counts. During the initial year (2001), 69 of the 120 original random points were surveyed, with three points per transect for a total of 207 point counts. These original 69 transects became the targeted transects for survey each subsequent year through 2007. Although we attempted to conduct point-count surveys on all points every year, weather conditions and time restrictions prevented this from occurring some years.

\section{Survey Timing}

Across all years, point-count survey work commenced on or after 21 May (usually after 1 June) and was completed on or before 12 July; effort was made each year to complete all counts by the end of June. Except for two transects during 2001, point counts began as early as sunrise and were completed by 10:37. During the start of the project, Paul Hendricks observed the level of vocalization of prairie birds in the evening hours appeared comparable to the early morning hours and conducted six point counts (two transects) in the evening hours, between 19:00 and 19:40. Subsequently, the decision was made to restrict surveys to the morning hours, although studies in grasslands elsewhere (Swengel and Swengel 2000) indicated no single period of the day was optimal for detecting all bird species.

\section{Avian Point-Count Methodology}

All point counts were ten minutes in duration and conducted within approximately five hours following sunrise (and generally not earlier than 05:50). During each point count, birds observed during time intervals of $0-3$ minutes,

Table 1. Summary of observers, number of transects, and number of point counts each year

\begin{tabular}{|c|c|c|c|c|}
\hline Year & $\begin{array}{l}\text { Total Number of } \\
\text { Transects }\end{array}$ & $\begin{array}{l}\text { Total Number } \\
\text { of Point Counts }\end{array}$ & Observer & $\begin{array}{c}\text { Number of } \\
\text { Point Counts by } \\
\text { Observer }\end{array}$ \\
\hline \multirow{2}{*}{2001} & \multirow{2}{*}{69} & \multirow{2}{*}{207} & Paul Hendricks & 117 \\
\hline & & & $\begin{array}{l}\text { John Carlson } \\
\end{array}$ & 90 \\
\hline \multirow{2}{*}{2002} & \multirow{2}{*}{69} & \multirow{2}{*}{207} & Paul Hendricks & 117 \\
\hline & & & John Carlson & 90 \\
\hline \multirow{2}{*}{2003} & \multirow{2}{*}{63} & \multirow{2}{*}{189} & Paul Hendricks & 117 \\
\hline & & & John Carlson & 72 \\
\hline \multirow{4}{*}{2004} & \multirow{4}{*}{65} & \multirow{4}{*}{195} & Paul Hendricks & 93 \\
\hline & & & John Carlson & 18 \\
\hline & & & Susan Lenard & 45 \\
\hline & & & Coburn Currier & 39 \\
\hline \multirow{3}{*}{2005} & \multirow{3}{*}{66} & \multirow{3}{*}{198} & Paul Hendricks & 69 \\
\hline & & & Susan Lenard & 81 \\
\hline & & & Coburn Currier & 48 \\
\hline \multirow{3}{*}{2006} & \multirow{3}{*}{69} & \multirow{3}{*}{207} & Paul Hendricks & 72 \\
\hline & & & Susan Lenard & 63 \\
\hline & & & Coburn Currier & 72 \\
\hline \multirow{3}{*}{2007} & \multirow{3}{*}{69} & \multirow{3}{*}{207} & Paul Hendricks & 72 \\
\hline & & & Susan Lenard & 54 \\
\hline & & & Coburn Currier & 81 \\
\hline
\end{tabular}


3 - 5 minutes, and 5 - 10 minutes were recorded separately. All birds detected visually and/or aurally within a visually-estimated 100 meter radius circle surrounding the center point were included in the tally. Each individual species was documented with the appropriate 4-letter AOU code, abundance noted, and identified as within the $100 \mathrm{~m}$ circle, on the edge, or outside of the circle. Birds that flew over the circle and did not land during the count were recorded as flyovers. Counts were not conducted during continuous rain or winds generally exceeding about $12 \mathrm{mph}$ (20 $\mathrm{km} / \mathrm{hr}$ ).

The correlation of annual abundance and the percentage of point counts on which a given species occurs was strong (Spearman rank correlations: $\left.r_{s}=0.600-0.912, P=0.175-0.017\right)$, for seven passerine Species of Concern recorded annually in north Valley County. Thus, it is still possible to infer the general trend of species abundances in this landscape, similar to results reported in analysis of Breeding Bird Survey data (Bart and Klosiewski 1989), even if two observers do not detect equally the number of individuals of each species on point counts.

\section{Vegetation Measurement Protocols}

Vegetation measurements were recorded at each bird point-count location. The point location defined the center of a $25-\mathrm{m}$ diameter circle for which were recorded maximum vegetation height, an index vegetation density (see below), litter depth, and ground cover. Ground cover measurements were taken along a $50 \mathrm{~m}$ straight line inscribed in each circle, with end points at opposite cardinal compass directions. At each meter along this transect, ground cover was recorded as bare ground (including rock) or nonbare ground (grass/forb/clubmoss). The center (the original point-count location) was not included in the ground cover measurements.
An index of vegetation density was recorded at points in each of the 4 cardinal directions $25 \mathrm{~m}$ from the center of the point-count circle. At each of these points, a 1-m rod was held vertical to the ground, and all vegetation contacts with the rod were recorded in 1-dm increments $(0-1 \mathrm{dm}, 1-2$ $\mathrm{dm}$, or $>2 \mathrm{dm}$ ). The plant contacts were recorded as either grass or forb and alive or dead. For maximum height, the height of the tallest plant within a $1 \mathrm{~m}$ radius of each point was recorded to the nearest $\mathrm{cm}$. Litter depth, to the nearest $\mathrm{cm}$, was also recorded at each of the four points where the vegetation density index was measured.

\section{Precipitation}

Precipitation data was gathered from the Opheim (OPMM8) NOAA weather station in north Valley County (see Figure 1) to examine relationships between spring (April-May) precipitation and vegetation characteristics that could influence bird settlement and presence on point counts. Total precipitation for these two months was chosen as most likely to influence the vegetation conditions birds will find when they commence nesting in this region (Davis 2003).

\section{Statistical Analyses}

For most analyses we favored use of nonparametric procedures to avoid assumptions of continuity, normality, or homogeneity of variances. We used parametric or nonparametric correlations or simple linear regression for examining the influence of precipitation on continuous vegetation variables or exploring relationships between vegetation and precipitation variables with bird presence. For among-year or among-species analyses, we used nonparametric Kruskal-Wallis ANOVAs. Nonparametric Wilcoxon Rank Sums tests were used for analyses of site vegetation structure expressed either as continuous values or as percents. We used non-parametric tests for all analyses of association (two-by-two tables and proportions). All analyses were run on STATISTIX ( 8 (Analytical Software, Tallahassee, Florida). 
Table 2. Bird species of conservation interest occurring on point counts in north Valley County during 2001-2007.

\begin{tabular}{|c|c|c|c|c|}
\hline Common Name & Scientific Name & $\begin{array}{l}\text { Global } \\
\text { and State } \\
\text { Ranks }^{\mathrm{a}}\end{array}$ & $\begin{array}{l}\text { BLM } \\
\text { Status }^{b}\end{array}$ & $\begin{array}{l}\text { PIF } \\
\text { Rank }^{\mathrm{c}}\end{array}$ \\
\hline American White Pelican & Pelecanus erythrorhynchos & G3/S3B & & III \\
\hline Greater Sage-Grouse & Centrocercus urophasianus & G4/S3B & Sensitive & $\mathrm{I}$ \\
\hline Northern Harrier & Circus cyaneus & & & III \\
\hline Swainson's Hawk & Buteo swainsoni & G5/S3B & Sensitive & \\
\hline Ferruginous Hawk & Buteo regalis & G4/S3B & Sensitive & II \\
\hline Killdeer & Charadrius vociferous & & & III \\
\hline Willet & Catoprophorus semipalmatus & & Sensitive & III \\
\hline Long-billed Curlew & Numenius americanus & $\mathrm{G} 5 / \mathrm{S} 2 \mathrm{~B}$ & Sensitive & II \\
\hline Marbled Godwit & Limosa fedoa & & Sensitive & \\
\hline Wilson's Phalarope & Phalaropus tricolor & & Sensitive & III \\
\hline Franklin’s Gull & Larus pipixcan & G4G5/S3B & Sensitive & II \\
\hline Common Tern & Sterna hirundo & G5/S3B & & II \\
\hline Loggerhead Shrike & Lanius ludovicianus & G4/S3B & Sensitive & II \\
\hline Short-eared Owl & Asio flammeus & & & III \\
\hline Sprague's Pipit & Anthus spragueii & G4/S2B & Sensitive & $\mathrm{I}$ \\
\hline Clay-colored Sparrow & Spizella pallida & & & III \\
\hline Brewer's Sparrow & Spizella breweri & G5/S2B & Sensitive & II \\
\hline Lark Sparrow & Chondestes grammacus & & & III \\
\hline Lark Bunting & Calamospiza melanocorys & G5/S3B & & II \\
\hline Grasshopper Sparrow & Ammodramus savannarum & G5/S2B & & II \\
\hline Baird's Sparrow & Ammodramus bairdii & G4/S2B & Sensitive & $\mathrm{I}$ \\
\hline McCown's Longspur & Calcarius mccownii & G5/S2B & Sensitive & II \\
\hline Chestnut-collared Longspur & Calcarius ornatus & G5/S3B & Sensitive & II \\
\hline Bobolink & Dolichonyx oryzivorous & G5/S2B & & III \\
\hline Red-winged Blackbird & Agelaius phoeniceus & & & III \\
\hline Brewer's Blackbird & Euphagus cyanocephalus & & & III \\
\hline
\end{tabular}

\section{a Appendix A}

$(\mathbf{G}=$ global rank status : $\mathbf{S}=$ state rank status $)$

G2 or S2 -At risk: very limited and/or declining populations, range, and/or habitat, making it vulnerable to global extinction or extirpation in the state.

G3 or S3 -Potentially at risk: limited and/or declining populations, range, and/or habitat, even though it may be abundant in some areas.

G4 or S4 -Uncommon but not rare (although it may be rare in parts of its range), and usually widespread. Apparently not vulnerable in most of its range, but possibly cause for long-term concern.

G5 - Common and abundant (although it may be rare in parts of its range), and usually widespread.

B - State rank modifier indicating the breeding status for a migratory species.

${ }^{b}$ BLM Status

Sensitive: species proven imperiled in at least part of their ranges, and are documented to occur on BLM lands.

c Montana Partners in Flight Priority Levels

I Conservation Action: These are species for which Montana has clear obligations to implement conservation.

II Monitoring Species: Montana has a high responsibility to monitor the status of these species, and/or to design conservation actions.

III Local Concern: Presence of these species may serve as added criteria in the design and selection of conservation or monitoring strategies (Casey 2000). 


\section{Results}

\section{Overview}

We conducted 1410 point counts in north Valley County during 2001-2007 (Table 1); more than 75 species of birds were detected at least once (see Lenard et al. 2006, Hendricks et al. 2007). We recorded 28 species either actually on or flying over the points in 2007. Of the total species detected on point counts across all years, 16 are Montana Species of Concern (SOC) (Table 2 - preceding page) (MTNHP and MFWP 2006). Seven of these species are also endemic to the Northern Great Plains: Ferruginous Hawk, Long-billed Curlew, Sprague's Pipit, Lark Bunting, Baird's Sparrow, McCown's Longspur, and Chestnut-collared Longspur (Samson and Knopf 1996). Nine additional species are secondary, more widespread species of the prairie: Sharp-tailed Grouse, Northern Harrier, Swainson's Hawk, Upland Sandpiper, Short-eared Owl, Horned Lark, Vesper Sparrow, Bobolink, and Western Meadowlark (Samson and Knopf 1996). Another ten species not currently listed as state SOC are identified either as BLM Sensitive Species (Table 2) or as Species of Conservation Concern in the Montana Partner's in Flight Draft Bird Conservation Plan for Montana (Casey 2000, BLM 2004).

Twenty bird species were documented on point counts every year during 2001 through 2007 (Table 3). This suite of 20 species probably includes most of those breeding regularly and occurring widely in grassland habitats in north Valley County. A few additional species, such as Ring-necked Pheasant, Upland Sandpiper, and Wilson's Phalarope, were detected every year but not every year within point-count circles, and are not included in the following analyses. The regular breeders include nine Montana SOC birds and two others that are BLM Sensitive Species. Thus, $55 \%$ of the species documented every year within point-count circles in north Valley County are of designated conservation concern. Sparrows and buntings comprise the largest group of species (8) documented annually, and six (75\%) are Montana SOC birds. Eight of nine Montana SOC birds are passerines, the ninth is the Long-billed Curlew, a grassland-nesting shorebird.
Table 3. Bird species detected every year (2001-2007) within north Valley County, Montana point-count circles. Montana SOC species are indicated by an asterisk, BLM Sensitive Species by a plus symbol. Number of point counts each year: $189-207$.

\begin{tabular}{|c|c|}
\hline Species & $\begin{array}{c}\text { \% Points } \\
\text { detected (range) }\end{array}$ \\
\hline \multicolumn{2}{|l|}{ Grouse } \\
\hline Sharp-tailed Grouse & $1.4-2.9$ \\
\hline \multicolumn{2}{|l|}{ Shorebirds } \\
\hline Killdeer & $2.1-3.4$ \\
\hline Willet + & $1.0-4.5$ \\
\hline Long-billed Curlew*+ & $1.9-8.6$ \\
\hline Marbled Godwit + & $2.6-13.6$ \\
\hline \multicolumn{2}{|l|}{ Larks } \\
\hline Horned Lark & $73.9-78.7$ \\
\hline \multicolumn{2}{|l|}{ Pipits/Wagtails } \\
\hline Sprague's Pipit*+ & $49.8-71.4$ \\
\hline \multicolumn{2}{|l|}{ Sparrows/Buntings } \\
\hline Brewer's Sparrow*+ & $1.4-5.8$ \\
\hline Vesper Sparrow & $11.3-21.3$ \\
\hline Lark Bunting* & $6.8-33.3$ \\
\hline Savannah Sparrow & $5.8-14.5$ \\
\hline Grasshopper Sparrow* & $6.7-22.2$ \\
\hline Baird's Sparrow*+ & $30.4-46.4$ \\
\hline McCown's Longspur*+ & $13.5-28.5$ \\
\hline Chestnut-collared Longspur*+ & $79.7-89.9$ \\
\hline \multicolumn{2}{|l|}{ Blackbirds } \\
\hline Bobolink* & $0.5-5.3$ \\
\hline Red-winged Blackbird & $0.5-2.6$ \\
\hline Western Meadowlark & $61.4-72.7$ \\
\hline Brewer's Blackbird & $0.5-2.9$ \\
\hline Brown-headed Cowbird & $4.3-10.1$ \\
\hline
\end{tabular}

Some of the SOC birds are among the most abundant and widespread species on the north Valley County point counts. The five most commonly-encountered species included Horned Lark, Sprague's Pipit, Baird's Sparrow, Chestnutcollared Longspur, and Western Meadowlark, each of which occurred on at least $30.4 \%$ of all point counts each year (Table 3, Figure 2); Sprague's Pipit, Baird's Sparrow, and Chestnut-collared Longspur are state SOC birds. Other state SOC birds, such as Brewer's Sparrow and Bobolink, are among the least abundant and widespread. For the remainder of the main body of this report, we focus our analyses on the nine SOC birds, because the 
grassland habitats they favor include a wide range of vegetation structure. The nine focal species include, in addition to the five mentioned above, Long-billed Curlew, Lark Bunting, Grasshopper Sparrow, and McCown's Longspur.

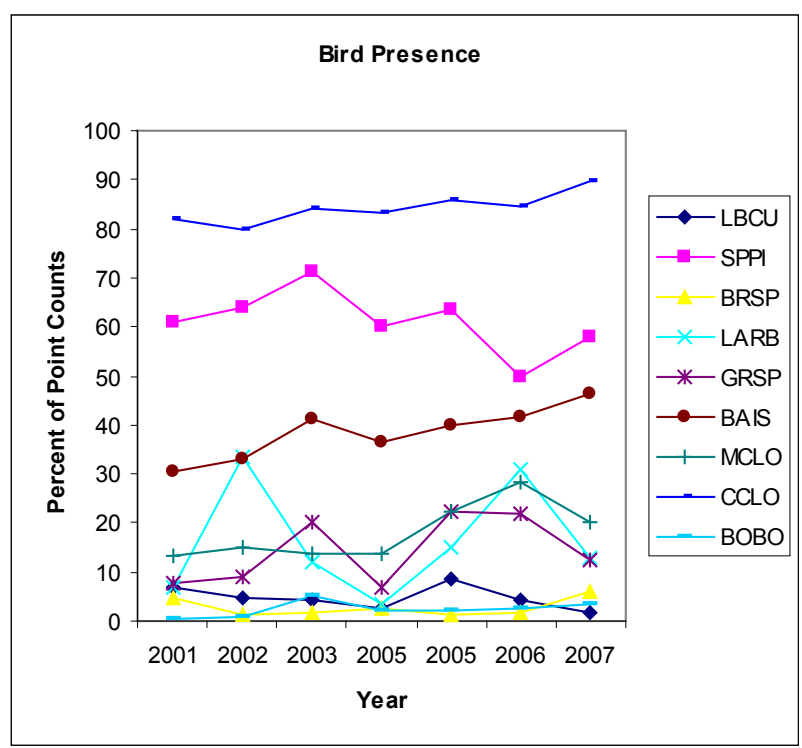

Figure 2. Occurrence of nine Montana bird Species of Concern on point counts in north Valley County during 20012007. Long-billed Curlew (LBCU), Sprague's Pipit (SPPI), Brewer's Sparrow (BRSP), Lark Bunting (LARB), Grasshopper Sparrow (GRSP), Baird's Sparrow (BAIS), McCown's Longspur (MCLO), Chestnut-collared Longspur (CCLO), and Bobolink (BOBO). Number of counts per year ranged from 189 to 207.

\section{Precipitation and Vegetation}

Total April and May precipitation at Opheim, the nearest NOAA weather station to our study area, (Figure 1) varied nearly five-fold during 20012007, from a low of $2.89 \mathrm{~cm}$ in 2002 to a high of $14.40 \mathrm{~cm}$ in 2007 (Table 4). With such variability in early growing-season precipitation it is not surprising that vegetation would show noticeable variation among years at the time we conducted our point counts (see Figure 3 for examples). Mean maximum vegetation height was least $($ mean $=$ $35.4 \mathrm{~cm})$ in 2002 and greatest $($ mean $=47.2 \mathrm{~cm})$ in 2007 (Table 5); vegetation density (number of contacts at $0-1 \mathrm{dm}$ above ground, and $>1 \mathrm{dm}$ above ground) was also least (mean $=15.0$ and 2.1 contacts, respectively) in 2002 and most (mean $=20.4$ and 5.3 contacts, respectively) in 2007 . Percent vegetation cover also showed substantial annual variation, with greatest cover in 2007 , although we were less consistent in taking this measurement some years and had to discount 2001 in our analyses.

Table 4. April and May precipitation (cm) measured at the Opheim station (OPMM8), north Valley County.

\begin{tabular}{|l|c|c|c|c|c|c|c|}
\hline & $\mathbf{2 0 0 1}$ & $\mathbf{2 0 0 2}$ & $\mathbf{2 0 0 3}$ & $\mathbf{2 0 0 4}$ & $\mathbf{2 0 0 5}$ & $\mathbf{2 0 0 6}$ & $\mathbf{2 0 0 7}$ \\
\hline April & 1.4 & 1.09 & 3.58 & 1.19 & 1.6 & 3.1 & 1.78 \\
\hline May & 3.4 & 1.8 & 6.93 & 8.79 & 4.93 & 3.81 & 12.62 \\
\hline Total & 4.8 & 2.89 & 10.51 & 9.98 & 6.53 & 6.91 & 14.4 \\
\hline
\end{tabular}

Total April-May precipitation was best at predicting mean maximum vegetation height (Pearson correlation: $r=0.878, \mathrm{P}=0.009$ ), explaining $77 \%$ of the variation among years on our points (Figure 4). Total April-May precipitation was not as strongly correlated with the other three vegetation measurements we collected (Table 5): $r=0.610, \mathrm{P}$ $=0.146$ for contacts $0-1 \mathrm{dm} ; r=0.779, \mathrm{P}=0.039$ for contacts $>1 \mathrm{dm}$; Spearman correlation $r_{s}=$ $0.657, \mathrm{P}=0.136$ for percent vegetation cover.

Among the vegetation structure measurements, annual mean vegetation height among years was moderately correlated with vegetation contacts $0-1 \mathrm{dm}$ above ground $(r=0.4862, \mathrm{P}=0.269)$, but very highly correlated with vegetation contacts $>1 \mathrm{dm}$ above ground $(r=0.9318, \mathrm{P}=0.002)$. Vegetation contacts in the two height categories

Table 5. Descriptive statistics (mean [SD]) for vegetation measurements at North Valley County point counts, 2001-2007.

\begin{tabular}{|l|c|c|c|c|c|c|c|c|}
\hline & $\mathbf{2 0 0 1}$ & $\mathbf{2 0 0 2}$ & $\mathbf{2 0 0 3}$ & $\mathbf{2 0 0 4}$ & $\mathbf{2 0 0 5}$ & $\mathbf{2 0 0 6}$ & $\mathbf{2 0 0 7}$ & $P^{1}$ \\
\hline \hline Veg. Ht. (cm) & $38.0(10.7)$ & $35.4(8.0)$ & $44.4(8.8)$ & $38.1(7.5)$ & $40.3(8.4)$ & $38.5(9.6)$ & $47.2(7.3)$ & $<0.0001$ \\
\hline Contacts 0-1 dm & $17.4(8.3)$ & $15.0(5.9)$ & $15.5(6.3)$ & $17.5(6.8)$ & $16.9(7.0)$ & $18.7(9.3)$ & $20.4(9.3)$ & $<0.0001$ \\
\hline Contacts $>\mathbf{1 ~ d m ~}$ & $2.9(4.1)$ & $2.1(2.7)$ & $3.6(4.5)$ & $2.2(2.7)$ & $30 .(3.7)$ & $3.0(5.1)$ & $5.3(5.0)$ & $<0.0001$ \\
\hline \% Veg. Cover & NA & $79.6(12.5)$ & $80.5(10.5)$ & $70.5(12.9)$ & $62.3(25.6)$ & $68.0(18.1)$ & $97.3(5.0)$ & $<0.0001$ \\
\hline No. Counts & 207 & 207 & 189 & 195 & 198 & 207 & 207 & \\
\hline
\end{tabular}

${ }^{1}$ Kruskal-Wallis ANOVA 

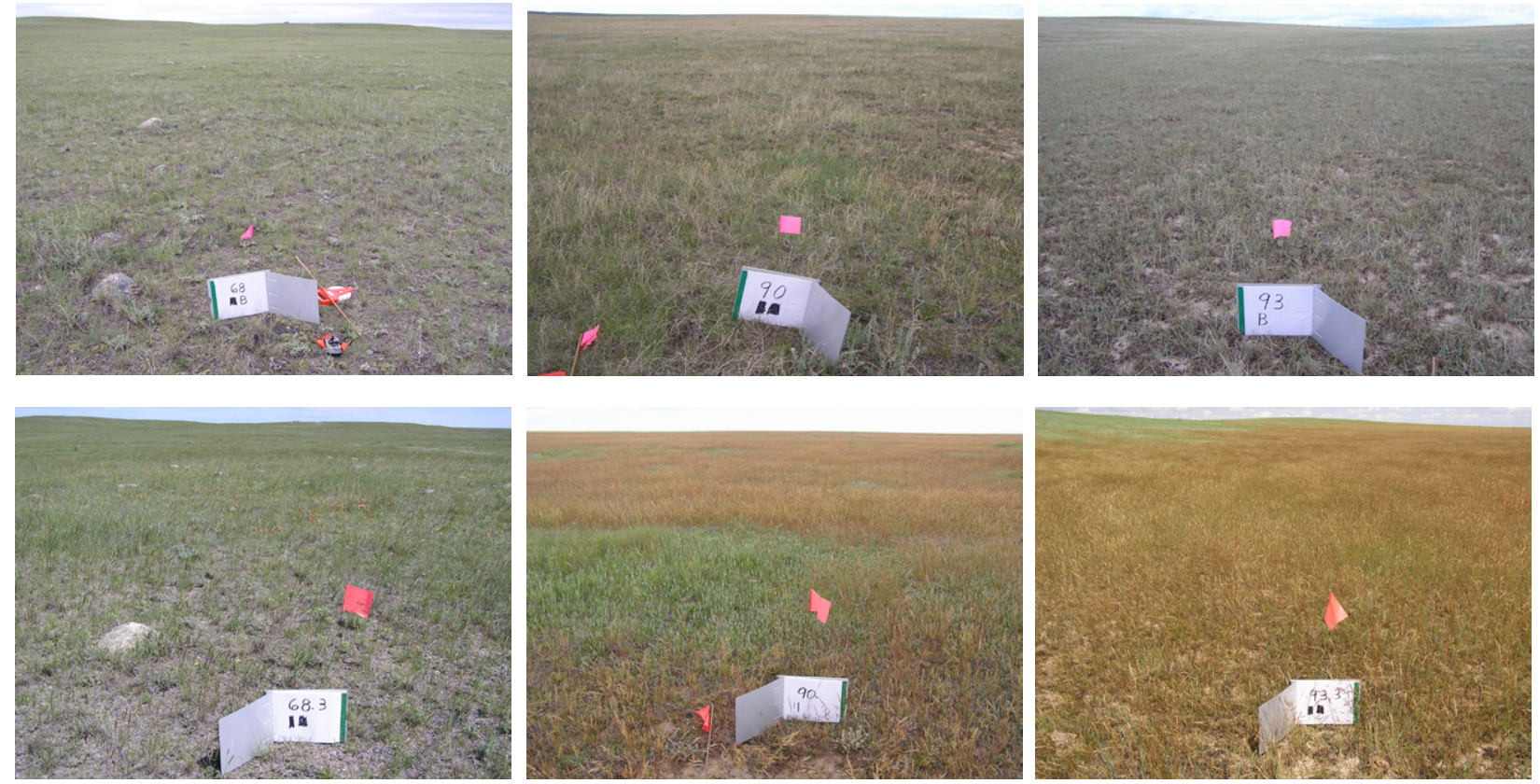

Figure 3. June vegetation on three count points $(68.3,90.1,93.3)$ in north Valley County, contrasting 2006 and 2007. Top row: 2006, bottom row: 2007. Note exceptional growth of Junegrass (Koeleria macrantha) on points in 2007.

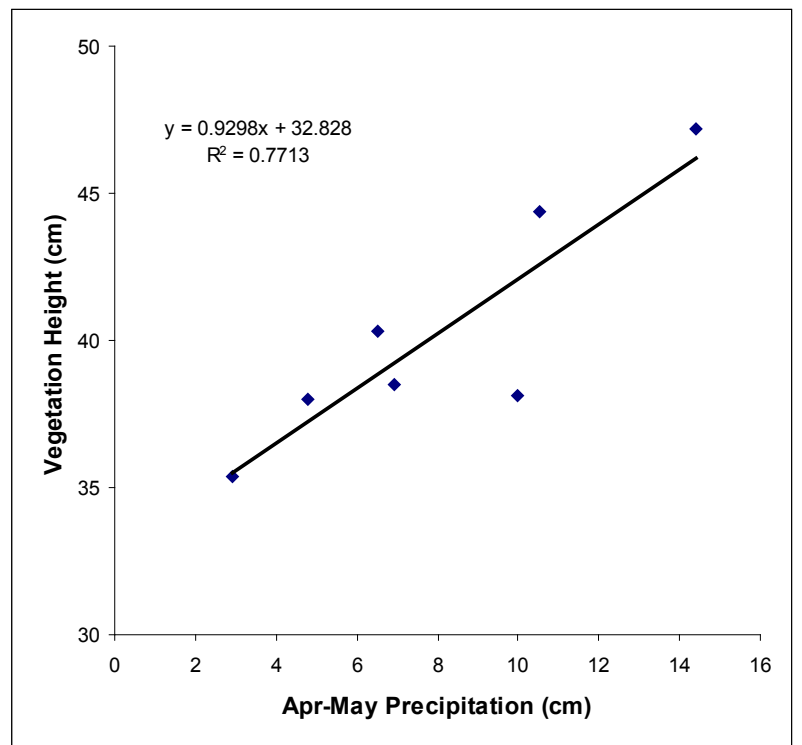

Figure 4. April-May precipitation and June vegetation height on count points, 2001-2007, in north Valley County. Precipitation was measured at Opheim.

were moderately correlated $(r=0.6660, \mathrm{P}$ $=0.102)$. Correlation between vegetation height and number of vegetation contacts $>1 \mathrm{dm}$ at points was consistently moderate within individual years $(r=0.3531-0.4949, \mathrm{P}<0.0001$ for each year). Correlation between vegetation contacts in the two height categories was usually weaker $(\mathrm{r}=$ $0.1857-0.5468)$, and weakest between vegetation height and vegetation contacts $0-1 \mathrm{dm}(\mathrm{r}=-0.0126-$ 0.2090).

\section{Precipitation and Annual Abundance of Species of Concern Birds}

Presence of SOC birds on points in north Valley County was sometimes moderately or highly correlated with annual April-May precipitation (Figure 5). Strongest correlations were those for Chestnut-collared Longspur $(r=0.8161)$, Baird's Sparrow $(r=0.7969)$, Bobolink $(r=0.7233)$, and Long-billed Curlew $(r=-0.6621)$, followed by Lark Bunting $(r=-0.4775)$, Brewer's Sparrow ( $r$ $=0.4685)$, with almost negligible correlations for Grasshopper Sparrow ( $r=0.1009)$, McCown's Longspur $(r=0.0595)$, and Sprague's Pipit ( $r$ $=-0.0044$ ). Of the nine SOC birds, two (Longbilled Curlew and Lark Bunting) showed a substantial negative relationship to annual spring precipitation. For the best regression models (Chestnut-collared Longspur and Baird's Sparrow), April-May precipitation accounted for $64-67 \%$ of annual variation in the percentage of point counts on which these species were detected, while for the worst regression models (Sprague's Pipit, McCown's Longspur) precipitation accounted for 
essentially none of the annual variation in percent occurrence on point counts.

\section{Vegetation Structure and Annual} Abundance of Species of Concern

\section{Birds}

Annual variation in the percentage of point counts on which the nine SOC birds occurred was highly correlated to vegetation structure only in a minority of cases (Table 6). Strongest correlations $\left(r_{s}>0.8\right)$ with vegetation height occurred for Baird's Sparrow, Chestnut-collared Longspur, and Bobolink, and were positive in each case. Moderate correlations $\left(r_{s}=0.4-0.7\right)$ were evident for Long-billed Curlew and Grasshopper Sparrow, negative for Long-billed Curlew but positive for Grasshopper Sparrow. For Sprague's Pipit, Brewer's Sparrow, Lark Bunting, and McCown's Longspur, the correlations were slight $\left(r_{s}<0.2\right)$ or weak $\left(r_{s}=0.2-0.4\right)$, and negative for Sprague's Pipit and Lark Bunting.

Annual variation in mean vegetation contacts > $1 \mathrm{dm}$ was very highly correlated with vegetation height $\left(r_{s}=0.9550, \mathrm{P}=0.0064\right)$, so only contacts
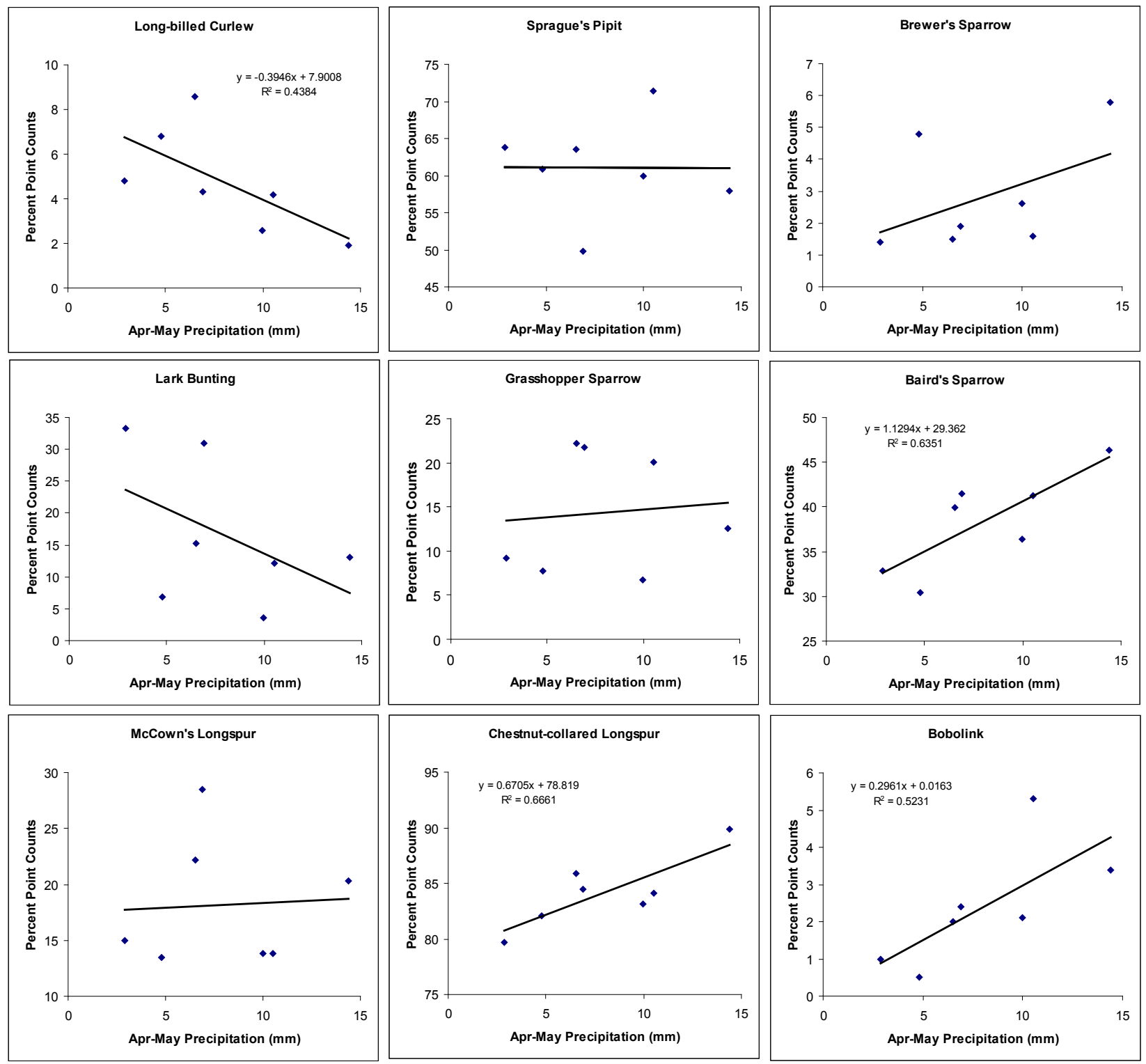

Figure 5. April-May precipitation in north Valley County during 2001-2007 (Opheim station) and the relative abundance of nine Montana bird Species of Concern. Regression equations are provided for correlations where $P<0.1$. 
Table 6. Spearman correlations between percent occurrence on point counts for nine SOC birds and vegetation height and vegetation density index (contacts), 2001-2007. Correlations where $P<0.05$ are in bold.

\begin{tabular}{|c|c|c|c|c|c|c|c|c|c|}
\hline & $\begin{array}{c}\text { Long-billed } \\
\text { Curlew }\end{array}$ & $\begin{array}{c}\text { Sprague's } \\
\text { Pipit }\end{array}$ & $\begin{array}{l}\text { Brewer's } \\
\text { Sparrow }\end{array}$ & $\begin{array}{c}\text { Lark } \\
\text { Bunting }\end{array}$ & $\begin{array}{c}\text { Grasshopper } \\
\text { Sparrow }\end{array}$ & $\begin{array}{l}\text { Baird's } \\
\text { Sparrow }\end{array}$ & $\begin{array}{l}\text { McCown's } \\
\text { Longspur }\end{array}$ & $\begin{array}{l}\text { Chestnut- } \\
\text { collared } \\
\text { Longspur }\end{array}$ & Bobolink \\
\hline \multicolumn{10}{|l|}{ Veg. Ht. (cm) } \\
\hline $\mathbf{r}_{\mathrm{s}}$ & -0.4643 & -0.1429 & 0.3214 & -0.1071 & 0.5357 & 0.8571 & 0.3424 & 0.8929 & 0.8214 \\
\hline $\mathbf{P}$ & 0.3059 & 0.7813 & 0.4436 & 0.843 & 0.1944 & 0.019 & 0.4436 & 0.0118 & 0.0281 \\
\hline \multicolumn{10}{|l|}{$\begin{array}{l}\text { Contacts } \\
0-1 \mathrm{dm}\end{array}$} \\
\hline $\mathbf{r}_{\mathrm{s}}$ & -0.5357 & -0.9286 & 0.8214 & -0.25 & -0.0357 & 0.5714 & 0.3063 & 0.6071 & 0.3214 \\
\hline $\mathbf{P}$ & 0.2285 & 0.0118 & 0.0281 & 0.604 & 0.9684 & 0.1634 & 0.4948 & 0.1354 & 0.4436 \\
\hline
\end{tabular}

0-1 dm are examined for correspondence between vegetation density and annual variation in percentage occurrence of SOC birds on point counts. As with vegetation height, only a minority of species showed a strong correlation $\left(r_{s}>0.8\right)$ between vegetation density near the ground and percentage of point counts on which a species occurred (Table 6). Strong correlations were evident for Sprague's Pipit and Brewer's Sparrow, with Sprague's Pipit being negative. Moderate correlations $\left(r_{s}=0.4-0.7\right)$ were evident for Longbilled Curlew, Baird's Sparrow, and Chestnutcollared Longspur, with Long-billed Curlew being negative. Correlations for the remaining species were slight or weak $\left(r_{s}<0.4\right)$.

\section{Vegetation Structure and the Presence of Species of Concern Birds on Point Counts}

Differences among species in mean vegetation height and near-ground vegetation density (number of contacts $0-1 \mathrm{dm}$ on a vertical rod) were significant (Kruskal-Wallis ANOVAs, $\mathrm{P}<$ 0.0001) when 2001-2007 were combined (Table 7). However, some species clustered relatively close together in this two-dimensional structural space of vegetation (Figure 6), and pair-wise comparisons in vegetation structure were not significant $(P$ $\geq 0.05$ ) among these. Long-billed Curlew and McCown's Longspur clustered where there were low values for vegetation height and near-ground density, Chestnut-collared Longspur and Sprague's Pipit clustered where vegetation was medium in height and near-ground density, and Baird's Sparrow and Grasshopper Sparrow clustered more loosely where vegetation was relatively tall and dense near the ground; vegetation structure differences between Bobolink and Baird's Sparrow or Grasshopper Sparrow were not significant, but this was likely due to a small sample of points occupied by Bobolink $(n=32)$. Seven of the SOC birds segregated by vegetation structure in a relatively linear pattern, but Lark Bunting and Brewer's Sparrow did not quite fit the trend. Based just on absence of significant differences in pair-

Table 7. Vegetation height and vegetation density index (contacts) comparing points where nine SOC birds were detected and not detected, 2001-2007. Total point counts =1410. Values are means (SD); comparisons where $P<0.05$ are in bold.

\begin{tabular}{|c|c|c|c|c|c|c|c|c|c|}
\hline & $\begin{array}{c}\text { Long-billed } \\
\text { Curlew }\end{array}$ & $\begin{array}{l}\text { Sprague's } \\
\text { Pipit }\end{array}$ & $\begin{array}{l}\text { Brewer's } \\
\text { Sparrow }\end{array}$ & $\begin{array}{c}\text { Lark } \\
\text { Bunting }\end{array}$ & $\begin{array}{c}\text { Grasshopper } \\
\text { Sparrow }\end{array}$ & $\begin{array}{c}\text { Baird's } \\
\text { Sparrow }\end{array}$ & $\begin{array}{l}\text { McCown's } \\
\text { Longspur }\end{array}$ & $\begin{array}{l}\text { Chestnut- } \\
\text { collared } \\
\text { Longspur }\end{array}$ & Bobolink \\
\hline \multicolumn{10}{|l|}{ Veg. Ht. (cm) } \\
\hline Detected & $36.7(7.2)$ & $40.8(9.2)$ & $47.8(11.8)$ & $41.2(10.9)$ & $46.8(11.2)$ & $43.7(9.8)$ & $37.4(8.2)$ & $39.7(8.9)$ & $48.7(9.7)$ \\
\hline not detected & $40.4(9.6)$ & $39.3(10.0)$ & $40.0(9.4)$ & $40.1(9.2)$ & $39.1(8.7)$ & $38.1(8.7)$ & $40.9(9.7)$ & $43.1(11.7)$ & $38.8(9.2)$ \\
\hline $\mathrm{P}^{\mathrm{a}}$ & 0.0034 & $<0.0001$ & $<0.0001$ & 0.6721 & $<0.0001$ & $<0.0001$ & $<0.0001$ & 0.0005 & $<0.0001$ \\
\hline \multicolumn{10}{|l|}{$\begin{array}{l}\text { Contacts } \\
0-1 \mathrm{dm} \\
\end{array}$} \\
\hline Detected & $14.9(6.1)$ & $18.0(8.3)$ & $16.3(6.6)$ & $14.5(5.7)$ & $20.4(10.3)$ & $20.4(8.8)$ & $15.4(6.1)$ & $17.7(7.9)$ & $25.2(15.2)$ \\
\hline not detected & $17.5(7.9)$ & $16.4(6.9)$ & $17.4(7.9)$ & $17.9(8.1)$ & $16.9(7.3)$ & $15.5(6.5)$ & $17.8(8.1)$ & $15.4(7.1)$ & $17.2(7.5)$ \\
\hline $\mathrm{P}^{\mathrm{a}}$ & 0.0081 & 0.0002 & 0.3646 & $<0.0001$ & $<0.0001$ & $<0.0001$ & $<0.0001$ & $<0.0001$ & $<0.0001$ \\
\hline $\begin{array}{l}\text { Total points } \\
\text { where detected }\end{array}$ & 67 & 859 & 40 & 234 & 201 & 541 & 257 & 1186 & 32 \\
\hline
\end{tabular}

${ }^{\text {a } W i l c o x o n ~ R a n k-S u m s ~ T e s t ~}$ 
wise comparisons, Lark Bunting clustered with Long-billed Curlew but not McCown's Longspur. Brewer's Sparrow was the most obvious outlier, occupying tall vegetation with lower near-ground vegetation density and did not cluster with any other SOC bird.

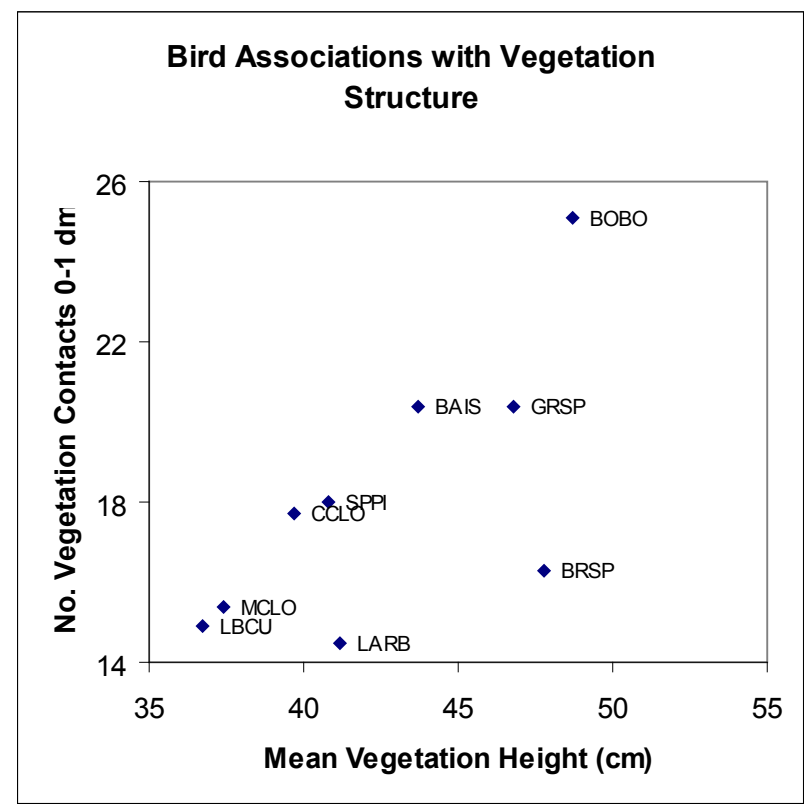

Figure 6. Ordination of nine Species of Concern birds on vegetation structure in north Valley County, Montana, based on mean values for 2001-2007 combined. Species acronyms: BAIS (Baird's Sparrow), BOBO (Bobolink), BRSP (Brewer's Sparrow), CCLO (Chestnut-collared Longspur), GRSP (Grasshopper Sparrow), LARB (Lark Bunting), LBCU (Longbilled Curlew), MCLO (McCown's Longspur), SPPI (Sprague's Pipit).

When data across the seven years of study was combined, points on which each SOC bird was detected differed in vegetation structure from points where each was not detected (Table 7). Substantial differences in vegetation height were evident for all species but Lark Bunting. Vegetation height was shorter where Long-billed Curlew, McCown's Longspur, and Chestnutcollared Longspur were detected and the variation in vegetation height for these points was relatively narrower. Long-billed Curlew tended to occupy the shortest vegetation $($ mean $=36.7 \mathrm{~cm})$, followed by McCown's Longspur $($ mean $=37.4 \mathrm{~cm})$ and Chestnut-collared Longspur $($ mean $=39.7 \mathrm{~cm})$. The remaining six species occupied points where vegetation tended to be taller and the variation in vegetation height for these points was relatively wider. Bobolink showed a tendency to occupy the tallest grassland vegetation $($ mean $=48.7 \mathrm{~cm})$, followed by Brewer's Sparrow $($ mean $=47.8 \mathrm{~cm}$ ) and Grasshopper Sparrow ( mean $=46.8 \mathrm{~cm}$ ); in this group Sprague's Pipit tended to occur where vegetation was shortest (mean $=40.8 \mathrm{~cm}$ ), although it merits emphasis that the variation around mean vegetation height for occupied points was at least $8 \mathrm{~cm}$ for all species, and there was overlap in occupied and unoccupied points for all species.

Substantial differences in mean vegetation density near the ground (contacts $0-1 \mathrm{dm}$ ) were evident for all species but Brewer's Sparrow (Table 7) for the combined seven years of data. Vegetation density was less on occupied than unoccupied points for Long-billed Curlew, Brewer's Sparrow, Lark Bunting, and McCown's Longspur, and greater on occupied points for the remaining five species. Lark Bunting and Long-billed Curlew occupied points with the least dense near-ground vegetation $(<15$ contacts) among the nine SOC birds, while Bobolink, Grasshopper Sparrow, and Baird's Sparrow occupied points with the densest near-ground vegetation (> 20 contacts). As with vegetation height, there was substantial variation in near-ground vegetation density for all points occupied by each species, with overlap in occupied and unoccupied points.

There was substantial (Kruskal-Wallis ANOVAs, $\mathrm{P}$ $<0.05$ ) between-year variation in mean vegetation height, near-ground vegetation density (contacts 0-1 dm), or both, on occupied points for all nine SOC birds except Brewer's Sparrow (Table 8). Differences were less substantial $(\mathrm{P}>0.05)$ among years for one of the two measures of vegetation structure on occupied points for three bird species: mean vegetation height for Grasshopper Sparrow and Bobolink, and near-ground vegetation density for Long-billed Curlew.

Among the nine SOC birds, Long-billed Curlew and McCown's Longspur tended to occupy points across all years with relatively short $(<40 \mathrm{~cm})$ and less dense near-ground vegetation (Table 8 ). The opposite was the pattern for Grasshopper Sparrow, Baird's Sparrow, and Bobolink. Sprague's Pipit and Chestnut-collared Longspur tended to occupy 
Table 8. Mean vegetation height and near-ground vegetation density (contacts 0-1 dm) for points occupied by nine Montana SOC birds. Standard deviations in parentheses. P-values (Kruskal-Wallis ANOVAs) are for among-year comparisons, with those $<0.05$ in bold.

\begin{tabular}{|c|c|c|c|c|c|c|c|c|}
\hline & 2001 & 2002 & 2003 & 2004 & 2005 & 2006 & 2007 & $\mathbf{P}$ \\
\hline \multicolumn{9}{|l|}{ Long-billed Curlew } \\
\hline height $(\mathrm{cm})$ & $35.1(8.1)$ & $33.3(5.4)$ & $37.6(5.3)$ & $37.3(6.3)$ & $39.4(6.3)$ & $32.6(6.9)$ & $46.2(7.5)$ & 0.0229 \\
\hline contacts $0-1 \mathrm{dm}$ & $15.2(5.8)$ & $11.8(6.2)$ & $12.3(3.1)$ & $14.0(4.1)$ & $17.4(6.8)$ & $14.4(6.5)$ & $18.6(6.1)$ & 0.2831 \\
\hline \multicolumn{9}{|l|}{ Sprague's Pipit } \\
\hline height $(\mathrm{cm})$ & $39.6(10.8)$ & $36.3(8.8)$ & $44.1(8.9)$ & $38.5(6.9)$ & $40.6(7.8)$ & $39.3(9.2)$ & $47.3(6.4)$ & $<0.0001$ \\
\hline contacts $0-1 \mathrm{dm}$ & $19.1(9.3)$ & $16.0(6.3)$ & $16.1(6.8)$ & $18.4(7.0)$ & $16.7(6.0)$ & $20.0(11.1)$ & $20.5(10.1)$ & $<0.0001$ \\
\hline \multicolumn{9}{|l|}{ Brewer’s Sparrow } \\
\hline height $(\mathrm{cm})$ & $45.5(16.0)$ & $43.5(8.9)$ & $48.5(8.0)$ & $44.5(11.1)$ & $51.9(6.8)$ & $39.6(12.2)$ & $53.6(9.2)$ & 0.2885 \\
\hline contacts $0-1 \mathrm{dm}$ & $15.4(5.2)$ & $15.0(2.4)$ & $19.3(9.2)$ & $15.2(7.2)$ & $10.7(1.5)$ & $13.5(7.5)$ & $19.5(7.2)$ & 0.2232 \\
\hline \multicolumn{9}{|l|}{ Lark Bunting } \\
\hline height $(\mathrm{cm})$ & $43.8(13.6)$ & $36.5(9.3)$ & $45.4(7.8)$ & $38.9(8.3)$ & $43.2(11.5)$ & $39.8(11.1)$ & $49.8(7.8)$ & $<0.0001$ \\
\hline contacts $0-1 \mathrm{dm}$ & $14.4(5.1)$ & $12.7(4.9)$ & $12.7(5.2)$ & $17.1(7.4)$ & $14.4(5.6)$ & $16.3(6.0)$ & $15.8(5.8)$ & 0.0031 \\
\hline \multicolumn{9}{|l|}{ Grasshopper Sparrow } \\
\hline height $(\mathrm{cm})$ & $52.0(14.4)$ & $44.6(12.1)$ & $46.8(9.0)$ & $47.6(11.5)$ & $45.8(10.6)$ & $44.6(13.0)$ & $50.7(6.9)$ & 0.0532 \\
\hline contacts $0-1 \mathrm{dm}$ & $19.0(7.4)$ & $14.5(6.7)$ & $18.1(8.0)$ & $19.0(7.4)$ & $19.1(7.1)$ & $24.5(13.1)$ & $24.5(13.4)$ & 0.0024 \\
\hline \multicolumn{9}{|l|}{ Baird's Sparrow } \\
\hline height $(\mathrm{cm})$ & $43.1(11.1)$ & $38.5(8.6)$ & $46.6(9.5)$ & $41.6(8.4)$ & $43.0(9.1)$ & $42.5(11.3)$ & $48.2(7.1)$ & $<0.0001$ \\
\hline contacts $0-1 \mathrm{dm}$ & $21.2(8.2)$ & $17.9(6.5)$ & $17.1(6.2)$ & $20.4(6.2)$ & $18.8(7.0)$ & $23.2(11.3)$ & $23.2(11.0)$ & $<0.0001$ \\
\hline \multicolumn{9}{|l|}{ McCown's Longspur } \\
\hline height $(\mathrm{cm})$ & $34.4(7.9)$ & $32.2(5.3)$ & $44.1(7.9)$ & $35.5(6.9)$ & $34.5(6.0)$ & $34.9(6.0)$ & $47.2(5.4)$ & $<0.0001$ \\
\hline contacts $0-1 \mathrm{dm}$ & $16.2(6.6)$ & $12.6(4.4)$ & $15.0(6.5)$ & $16.8(7.9)$ & $14.3(5.8)$ & $16.5(7.0)$ & $16.1(4.3)$ & 0.0188 \\
\hline \multicolumn{9}{|l|}{ Chestnut-collared Longspur } \\
\hline height $(\mathrm{cm})$ & $37.2(9.6)$ & $34.7(7.1)$ & $43.7(8.8)$ & $37.4(6.3)$ & $39.8(8.1)$ & $37.7(8.9)$ & $46.8(6.8)$ & $<0.0001$ \\
\hline contacts $0-1 \mathrm{dm}$ & $18.1(8.6)$ & $15.4(5.8)$ & $15.7(6.5)$ & $17.9(6.8)$ & $17.4(7.0)$ & $18.8(9.1)$ & $20.3(9.4)$ & $<0.0001$ \\
\hline \multicolumn{9}{|l|}{ Bobolink } \\
\hline height $(\mathrm{cm})$ & too few data & too few data & $46.9(8.3)$ & $58.0(10.5)$ & $44.3(2.7)$ & $52.0(16.4)$ & $51.9(4.4)$ & 0.1957 \\
\hline contacts $0-1 \mathrm{dm}$ & too few data & too few data & $17.1(8.5)$ & $20.0(4.4)$ & $20.5(9.5)$ & $34.0(15.8)$ & $39.7(19.2)$ & 0.0067 \\
\hline
\end{tabular}


points with vegetation of intermediate height and near-ground density, while Brewer's Sparrow and Lark Bunting occupied points with taller but less dense vegetation. An unusual amount of AprilMay precipitation in 2007 (Table 4) led to robust growth of prairie grasses (see Figure 3), tending to narrow the differences among species in vegetation height on occupied points; the 2007 effect was less noticeable for near-ground vegetation density.

Although there was substantial among-year variation for vegetation structure on occupied points for most of the nine SOC birds (Table 8), significant $(\mathrm{P}<0.05)$ within-year differences between occupied and unoccupied points were not always evident (Figure 7, Table 9). Long-billed Curlew had the fewest significant within-year comparisons, occupying points with significantly shorter vegetation only in 2003 and 2007, although it tended to occur on points where the vegetation was shorter and less dense every year but one (2005). Sprague's Pipit tended to occur on points where vegetation was slightly taller (significantly so in four years) and denser near the ground (significantly so in four years). Conditions on points occupied by Brewer's Sparrows remained relatively consistent among years, although vegetation was significantly taller during three years, and near-ground vegetation was significantly less dense during one of those years; these patterns may be a result of small sample sizes (40 occupied points across seven years). Lark Bunting occupied points where the vegetation tended to be less dense near the ground (significant in four years), but differences in vegetation height (taller on occupied points in all years) were consistently less pronounced. Grasshopper Sparrow was found in most years on points where vegetation was significantly taller (2003 being the only year with a weaker difference) and often denser near the ground. Only Baird's Sparrow displayed significant differences between occupied and unoccupied points in all years for both measures of vegetation structure, occurring on points where the vegetation was significantly taller and denser near ground level. Vegetation on points occupied by both longspur species tended to be shorter than on unoccupied points. However, McCown's Longspurs occupied points where the near-ground vegetation was also less dense (significant in four of seven years), while Chestnut-collared Longspur occupied points where near-ground vegetation was denser (significantly so in four years) than on unoccupied points, just the opposite pattern from its congener. Comparisons for Bobolink suffered from small sample sizes (32 occupied points across seven years), but this species consistently occurred on points where vegetation was taller (significantly so in three of five years with data sufficient to calculate means and standard deviations) and denser near the ground (significantly so in two of five years). 

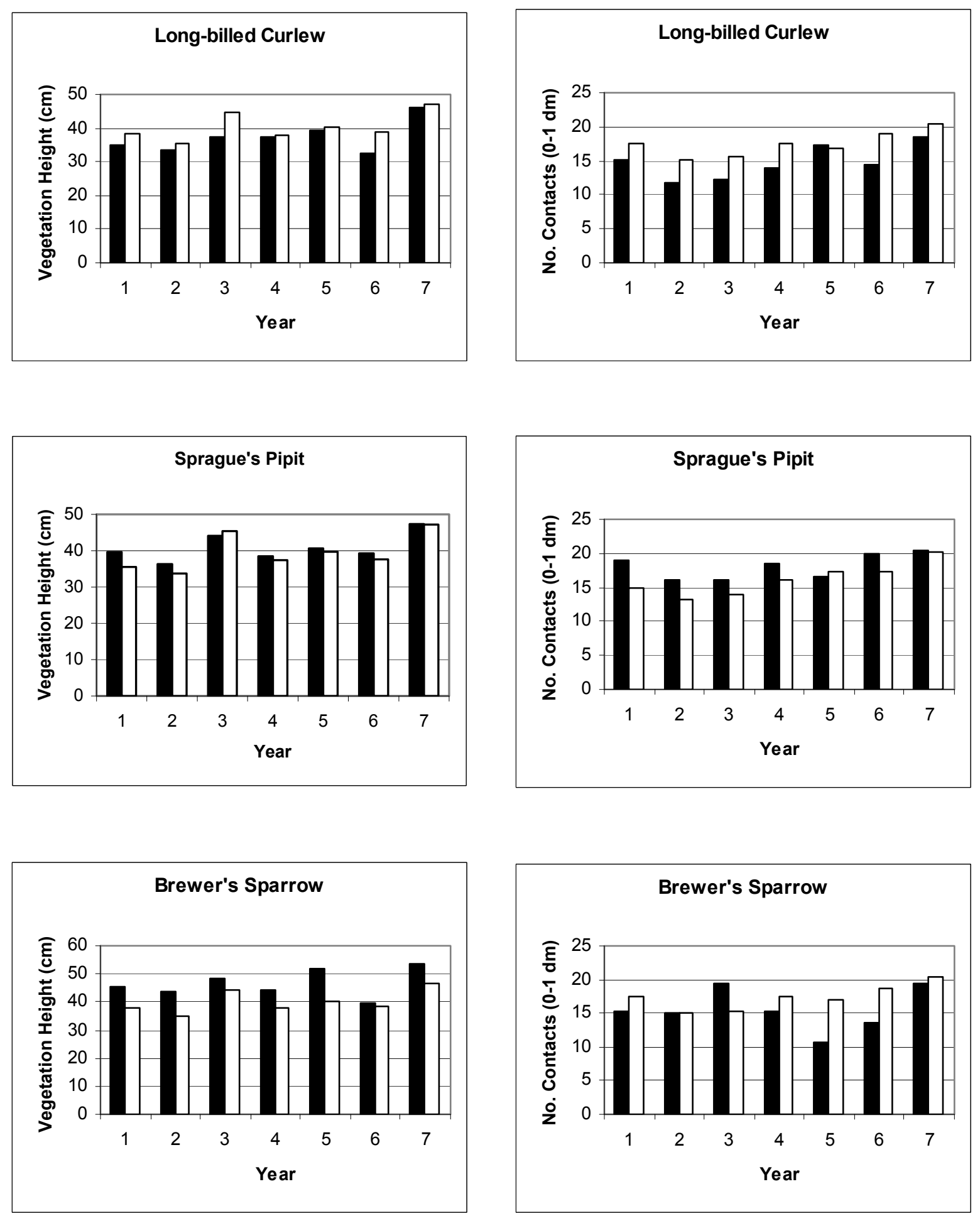

Figure 7. Vegetation height and vegetation density (number of rod contacts) for sites occupied by nine Montana bird Species of Concern in north Valley County during 2001-2007. Black bars are for points where species was detected, open bars for points where species was not detected. 

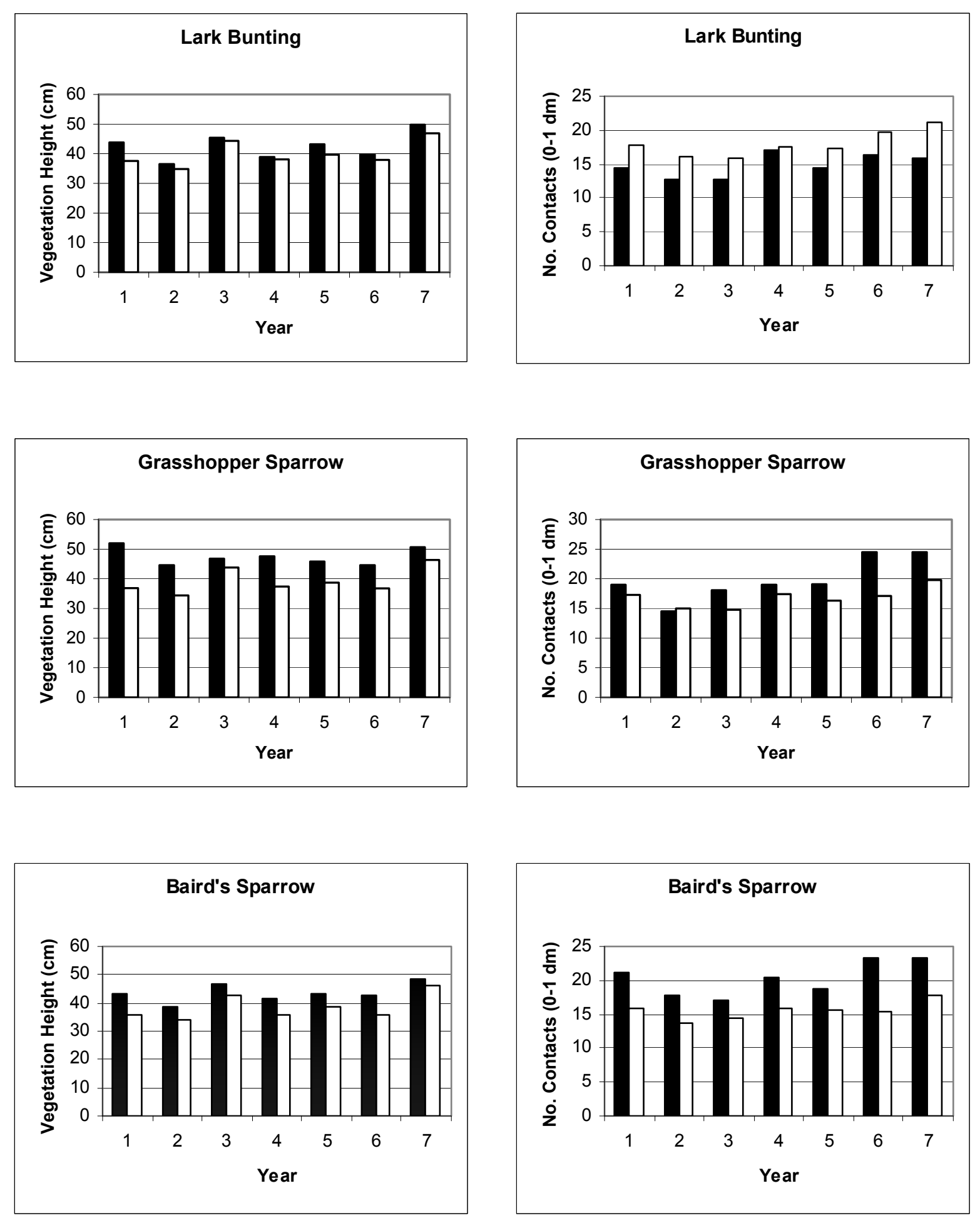

Figure 7. (Continued) Vegetation height and vegetation density (number of rod contacts) for sites occupied by nine Montana bird Species of Concern in north Valley County during 2001-2007. Black bars are for points where species was detected, open bars for points where species was not detected. 

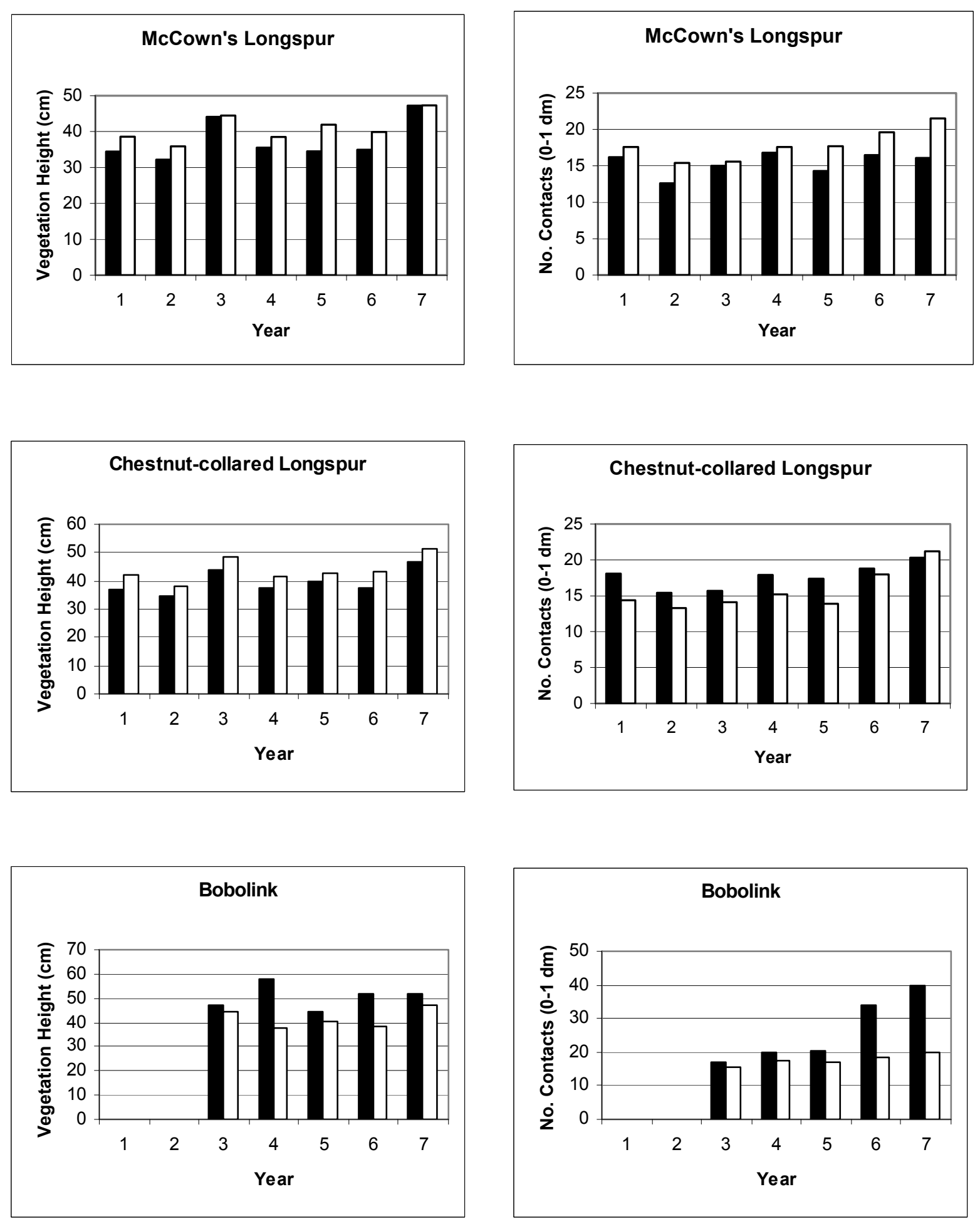

Figure 7. (Continued) Vegetation height and vegetation density (number of rod contacts) for sites occupied by nine Montana bird Species of Concern in north Valley County during 2001-2007. Black bars are for points where species was detected, open bars for points where species was not detected. 
Table 9. Mean vegetation height and density index (contacts $0-1 \mathrm{dm}$ ) comparisons for points where nine Montana SOC birds were detected and not detected (see Figure 7). P-values are based on Wilcoxin Rank-Sums tests; values $<0.05$ are in bold.

\begin{tabular}{|c|c|c|c|c|c|c|c|}
\hline & 2001 & 2002 & 2003 & 2004 & 2005 & 2006 & 2007 \\
\hline \multicolumn{8}{|c|}{ Long-billed Curlew } \\
\hline height & 0.5682 & 0.3589 & 0.0189 & 0.7621 & 0.8664 & 0.0168 & 0.652 \\
\hline density & 0.2718 & 0.119 & 0.0874 & 0.2255 & 0.7328 & 0.1185 & 0.9865 \\
\hline \multicolumn{8}{|l|}{ Sprague's Pipit } \\
\hline height & 0.0007 & 0.0245 & 0.4717 & 0.0475 & 0.2737 & 0.0463 & 0.4079 \\
\hline density & 0.0002 & 0.009 & 0.0276 & 0.0149 & 0.8708 & 0.2548 & 0.7276 \\
\hline \multicolumn{8}{|l|}{ Brewer's Sparrow } \\
\hline height & 0.1634 & 0.0493 & 0.3715 & 0.1602 & 0.0175 & 0.8761 & $\mathbf{0 . 0 0 9 7}$ \\
\hline density & 0.4336 & 0.7816 & 0.5379 & 0.5102 & 0.0435 & 0.1837 & 0.7693 \\
\hline \multicolumn{8}{|l|}{ Lark Bunting } \\
\hline height & 0.0944 & 0.6532 & 0.4218 & 0.4589 & 0.4282 & 0.2819 & 0.0751 \\
\hline density & 0.1535 & 0.0001 & 0.0161 & 0.8181 & 0.0167 & 0.0625 & $\mathbf{0 . 0 0 1 8}$ \\
\hline \multicolumn{8}{|c|}{ Grasshopper Sparrow } \\
\hline height & $<0.0001$ & 0.0002 & 0.0988 & 0.0003 & 0.0001 & 0.0002 & $\mathbf{0 . 0 0 3 6}$ \\
\hline density & 0.176 & 0.8436 & $\mathbf{0 . 0 0 3}$ & 0.5171 & 0.0159 & 0.0001 & $\mathbf{0 . 0 3 2 2}$ \\
\hline \multicolumn{8}{|l|}{ Baird's Sparrow } \\
\hline height & $<0.0001$ & $<0.0001$ & 0.0037 & $<0.0001$ & 0.003 & $<0.0001$ & 0.0278 \\
\hline density & $<0.0001$ & $<0.0001$ & 0.004 & $<0.0001$ & 0.0013 & $<0.0001$ & 0.0001 \\
\hline \multicolumn{8}{|c|}{ McCown's Longspur } \\
\hline height & 0.08 & 0.0028 & 0.8439 & 0.0663 & $<0.0001$ & 0.0012 & 0.7784 \\
\hline density & 0.2846 & 0.0046 & 0.6214 & 0.4572 & $\mathbf{0 . 0 0 3 3}$ & 0.0245 & 0.0008 \\
\hline \multicolumn{8}{|c|}{ Chestnut-collared Longspur } \\
\hline height & 0.1431 & 0.1399 & $\mathbf{0 . 0 0 5 3}$ & 0.1976 & 0.116 & 0.0104 & 0.1134 \\
\hline density & 0.0083 & $\mathbf{0 . 0 1 2 3}$ & 0.2181 & $\mathbf{0 . 0 4 9 3}$ & 0.018 & 0.4825 & 0.4923 \\
\hline \multicolumn{8}{|l|}{ Bobolink } \\
\hline height & too few data & too few data & 0.389 & 0.0067 & 0.0824 & 0.0444 & 0.0261 \\
\hline density & too few data & too few data & 0.6408 & 0.6408 & 0.3403 & 0.0035 & 0.0004 \\
\hline
\end{tabular}




\section{Discussion}

The prairie grasslands of north Valley County, Montana support several SOC birds endemic to the northern Great Plains, as well as other SOC grassland birds that breed more widely (Table 2). Nine SOC birds were detected on point counts each year of our seven-year study, and 11 other bird species also were observed on our counts every year (Table 3). Especially noteworthy is several species of conservation concern were also some of the most abundant breeding species on this prairie landscape. The bird occurring on the greatest percentage (79.7-89.9\%) of our point counts was Chestnut-collared Longspur, a Montana SOC bird; this species was previously recognized as the most abundant breeding bird across the northern Great Plains grasslands (Kantrud and Kologiski 1982). Next in order of relative abundance were Horned Lark, Western Meadowlark, Sprague's Pipit (SOC), and Baird's Sparrow (SOC); each species was detected every year on at least $30 \%$ of our count points. The percentages presented in Table 3 are generally conservative (compare with Table 3 in Hendricks et al. 2007), as most species were detected on additional point counts beyond the boundary of our $100 \mathrm{~m}$ fixed-radius count circles, data not included in the present report.

The nine SOC birds tended to segregate themselves across the north Valley County landscape on the basis of vegetation structure, as has been noted among grassland birds in other studies (Kantrud and Kologiski 1982, Dale et al. 1997, Davis et al, 1999, Madden et al. 1999, Madden et al. 2000, Johnson and Igl 2001, McMaster and Davis 2001). When data was pooled for all years of our study, mean vegetation structure on occupied points differed significantly from unoccupied points in both mean height and near-ground density for seven species, and in one of these two traits for the other two species (Table 7). A simple ordination using the two vegetation structure variables as axes (Figure 6) showed the nine SOC birds segregated across space into distinct species pairs or groups tending to occupy points sharing similar vegetation structure. Where these species fell on a relative vegetation-structure scale during our study in north Valley County are consistent with the studies previously noted, although only Kantrud and Kologiski (1982) addressed the full range of species we found, and their research focused on species distributions in relation to grazing and soils rather than directly on vegetation structure.

Comparison of vegetation structure on occupied and unoccupied points within years showed significant differences in one or both vegetation metrics for all SOC birds in at least two years, and usually four or more years (Table 9, Figure 7). Stronger differences might have been evident in more years if we had sampled vegetation from a larger area of each point-count circle, rather than just the core. Nevertheless, the patterns we detected by our sampling method tended to be consistent with prior studies, an encouraging result. In future studies using similar methods for sampling vegetation associated with bird presence, we suggest using a protocol that includes obtaining vegetation-structure data from random locations within each point-count circle.

Local climate conditions played a role in the annual variation in abundance of grassland bird species in north Valley County. In particular, the amount of April and May precipitation appears to have influenced the abundance of some Species of Concern, such as Long-billed Curlew, Baird's Sparrow, Chestnut-collared Longspur, and Bobolink (Figure 5), probably mediated through the effects of spring precipitation on vegetation structure (Table 5, Figure 4), although this contention was not uniformly supported by correlating annual species abundance with mean vegetation structure from all points (Table 6). Total precipitation for April and May was chosen as most likely to influence the vegetation conditions birds find when they commence nesting in this region (Davis 2003). Three species (Baird's Sparrow, Chestnut-collared Longspur, and Bobolink) associate with sites where vegetation is taller and denser than average or at least where vegetation provides more nest cover than random sites (Davis et al. 1999, Johnsgard 2001, Dieni and Jones 2003). Long-billed Curlew showed a negative response to increased spring precipitation, an expected pattern 
because this species selects sites with low-stature grass for nesting (Pampush and Anthony 1993, Johnsgard 2001, Dugger and Dugger 2002).

The remaining Species of Concern birds detected every year of our study (Table 3 ) had the weakest abundance correlations with April and May precipitation. The association of Brewer's Sparrow with shrub cover (Best 1972, Bock and Bock 1987, Paige and Ritter 1999) might contribute to a weaker abundance-precipitation relationship, as the short term structural response of shrubs to precipitation is likely less obvious through the kinds of measurements we recorded. Lark Bunting is more nomadic than the other species across a large region, and dramatic population fluctuations in north Valley County (Figure 2) are probably in part a response to drought conditions elsewhere (Yackel Adams et al. 2006, Lenard et al. 2006, Hendricks et al. 2007); Lark Bunting is also sometimes associated with a low density of shrubs (Feist 1968, Bock and Bock 1987, Johnsgard 2001). The weak relationship of Sprague's Pipit and Grasshopper Sparrow abundances with spring precipitation was unexpected. These species occur in denser and taller than average vegetation (Tables 7 and 9, Figure 7), but also relatively shrub-free (Johnsgard 2001), so a correlation similar to Baird's Sparrow or Bobolink (Figure 5) was anticipated in the case of Grasshopper Sparrow, and to Chestnut-collared Longspur in the case of Sprague's Pipit. However, as Kantrud and Kologiski (1982) allude, Sprague's Pipit appears to occur in relatively diverse conditions, and this flexibility may be reflected in the nearly flat abundance response to the variation in spring precipitation we noted in our study.

All species recorded are likely to breed on or near the project area, as field inventory occurred during the breeding season and observations included singing males and territorial displays in appropriate breeding habitat. Nest observations were not part of the survey protocol and have not been summarized at this time, but we confirmed breeding (nests with eggs or nestlings, or recently fledged dependent young) for the SOC birds detected each year on our point counts except Bobolink. This information has been loaded into the Montana Bird Distribution database (Lenard et al. 2003) and is available online through the Montana Natural Heritage Program Tracker website (http://nhp.nris.mt.gov/Tracker). This database confirms breeding or indicates indirect evidence of breeding for the project area in Valley County for most of the species observed during our project. 


\section{Conclusions}

North Valley County is an exceptional example of native northern Great Plains grassland, representing some of the most intact remaining prairie in Montana (Redmond et al. 1998) and the entire North American continent. The area, which lies adjacent to Canada's Grasslands National Park, is recognized nationally and internationally for its importance to prairie-dependent species (Cooper et al. 2001, Smith Fargey 2004). Seven of the ten most abundant species recorded each year during this project (Table 3, Figure 2) are state Species of Concern (MTNHP and MTFWP 2006). Five are Great Plains prairie endemic birds (Samson and Knopf 1996) and are present at greater abundances here than other regions in Montana (Cooper at al. 2001). The size of this large block of public rangeland in north Valley County makes it especially important to species with very limited breeding distributions, such as McCown's Longspur (With 1994), Baird's Sparrow (Green et al. 2002) and Sprague's Pipit (Robbins and Dale 1999), and those species dependent upon larger expanses of land, such as Baird's Sparrow, Bobolink, and Marbled Godwit (GrattoTrevor 2000, Johnson and Igl 2001). The relative importance of this area of Montana to the nine grassland Species of Concern, as well as Mountain Plover, and Greater Sage-Grouse is also highlighted in the composite image of predicted distributions for these species shown in Appendix C.

While the historical combination of bison, pronghorn, elk, locusts, and fire created a wide range of site conditions long past, land management activities can mimic characteristics of this historically heterogeneous landscape by creating areas with low, sparse vegetative structure to those with taller, denser vegetation (Gillihan and Hutchings 2000). Each of these habitat conditions is suited to individual prairie-dependent species. Primary prairie endemics generally have more restricted breeding ranges with less flexibility in habitat requirements than more generalist species (Davis et al. 1999). It is important to recognize the subtle differences in foraging and breeding habitat requirements for each species when land management activities are considered (see Appendix B in Lenard et al. 2006), but our study also showed bird species occupy grasslands where vegetation structure can vary relatively substantially from one year to the next (Tables 5, 8 and 9, Figure 7). Providing suitable foraging and breeding sites to a diverse assemblage of avifauna will require a mosaic of vegetation characteristics likely to be beneficial to a host of other prairie species. 


\section{Summary ANd Recommendations}

The present diversity and abundance of prairieendemic bird species in north Valley County indicates habitat elements in this area may be closer to historical conditions than other areas in the state. In addition, the different habitat requirements favored by each SOC bird recorded annually during this study (Figure 6) indicate a diversity of habitats is available. Given modern rangeland management objectives to remove approximately half of the annual growth through grazing (Adams et al. 2004, Holechek et al. 2003), it is not surprising that Sprague's Pipits and Chestnut-collared Longspurs, which show a preference for areas with moderate grass cover and litter, (Hill and Gould 1997, Robbins and Dale 1999) were two of the most commonly encountered birds during this study. It is encouraging to note, however, both Baird's Sparrows, which require denser grass and litter (Green et al. 2002), and McCown's Longspurs, which require sparse short grass and bare ground (With 1994), also were two of the most numerous bird species detected on points each year (Table 3 , Figure 2).

The current manageable activity affecting the remaining native grasslands is grazing by livestock. In contrast to concerns that current grazing practices do not provide a range of habitats, management in north Valley County appears to be providing habitat suitable to a diversity of prairie endemic species. At primary issue, however, is whether current management activities address grassland bird population objectives and if current conditions are sufficient to sustain these prairie species in the long term. Although this landscape was shaped by thousands of years of grazing by bison, the effect of domestic cattle grazing on vegetation structure and density can differ markedly from that of bison (Peden et al. 1974, Schwartz and Ellis 1981). However, grazing effects of cattle and bison can be similar at the right scale. This scale is dependent, certainly, upon the species in question and the ability of land managers to address habitat elements specific to each species. Maintaining both grazing and other natural disturbance (e.g. fire) regimes that mimic the frequency and intensity of historic conditions will result in a mosaic of vegetation structures. These conditions are critical to supporting high species diversity; without them many species would likely disappear from this landscape. Valley, Phillips, and Blaine Counties are critical to the conservation of Montana's grassland bird species (see composite image of predicted distributions for these species shown in Appendix C).

Continued work is needed, however, to identify the impacts of current land management practices on the future of these unique SOC birds. With analyses of grazing intensity impacts on vegetation measurements in point-count circles, we expect to see the response of breeding birds to vegetation structure more clearly, and this will help guide future grazing prescriptions. Of special interest would be an examination of the interaction of spring precipitation and grazing intensity on yearto-year variation in vegetation structure. From the results presented in this report, it is very clear that range conditions for birds in north Valley County can be quite variable in space and time (for example, see Figure 3), and yet a large diversity of birds with significant differences in preferred breeding grassland habitat continue to occur on the study area every year. 


\section{Literature Cited}

Adams, B. W., L. Poulin-Klein, D. Moisey and R. L. McNeil. 2004. Rangeland plant communities and range health assessment guidelines for the mixed grass natural subregion of Alberta. Report T/03940. Public Lands Division, Alberta Sustainable Resource Development. Lethbridge AB.

Askins, R. A., F. Chávez-Ramírez, B. C. Dale, C. A. Haas, J. R. Herkert, F. L. Knopf, and P. D. Vickery. 2007. Conservation of grassland birds in North America: understanding ecological processes in different regions. Ornithological Monographs No. 64. 46 pp.

Bart, J., and S. P. Klosiewski. 1989. Use of presence-absence to measure changes in avian density. Journal of Wildlife Management 53:847-852.

Best, L. B. 1972. First-year effects of sagebrush control on two sparrows. Journal of Wildlife Management 36:534-544.

Blann, K. 2006. Habitat in agricultural landscapes: how much is enough? A state-of-the science literature review. Defenders of Wildlife. Washington, D.C. 84 pp.

Bock, C. E., and J. H. Bock. 1987. Avian habitat occupancy following fire in a Montana shrubsteppe. Prairie Naturalist 19:153-158.

Bureau of Land Management. 2004. Montana/ Dakotas BLM Sensitive Species List 2004. http://www.blm.gov/nhp/efoia/mt/2004/im/ 04mtm082.pdf.

Casey, D. 2000. Montana Partners in Flight. Draft Conservation Plan Montana. January 2000. Kalispell, Montana. 281 pp.

Cooper, S. V., C. Jean, and P. Hendricks. 2001. Biological Survey of a Prairie Landscape in Montana's Glaciated Plains. Report to the Bureau of Land Management. Montana Natural Heritage Program, Helena. 24 pp. plus appendices.
Dale, B. C., P. A. Martin, and P. S. Taylor. 1997. Effects of hay management on grassland songbirds in Saskatchewan. Wildlife Society Bulletin 25:616-626.

Davis, S. K. 2003. Nesting ecology of mixed-grass prairie songbirds in southern Saskatchewan. Wilson Bulletin 115:119-130.

Davis, S K., D. C. Duncan, and M. Skeel. 1999. Distribution and habitat associations of three endemic grassland songbirds in southern Saskatchewan. Wilson Bulletin 111(3):389-396.

Dieni, J. S., and S. L. Jones. 2003. Grassland songbird nest site selection patterns in northcentral Montana. Wilson Bulletin 115:388396.

Drapeau, P., A. Leduc, and R. McNeil. 1999. Refining the use of point counts at the scale of individual points in studies of bird-habitat relationships. Journal of Avian Biology 30:367382.

Dugger, B. D. and K. M. Dugger. 2002. Longbilled Curlew (Numenius americanus). In The Birds of North America, No. 628. (A. Poole and F. Gill, eds.) The Birds of North America, Inc., Philadelphia, PA. 28 pp.

Feist, F. G. 1968. Breeding-bird populations on sagebrush-grassland habitat in central Montana. Audubon Field Notes 22:691-695.

Fitzgerald, J., D. Pashley, and B. Pardo. 1999. Partners in Flight Bird Conservation Plan for The Northern Mixed-grass Prairie (Physiographic Area 37). American Bird Conservancy, Jefferson City, Missouri. 65 pp.

Gillihan, S. W., and S. W. Hutchings. 2000. Best management practices for shortgrass prairie birds: a landowner's guide. Colorado Bird Observatory, Brighton, CO. 32 pp. 
Gratto-Trevor, C. L. 2000. Marbled Godwit (Limosa fedoa). In The Birds of North America, No. 492 (A. Poole and F. Gill's, eds.) The Birds of North America, Inc., Philadelphia, PA. 24 pp.

Green, M. T., P. E. Lowther, S. L. Jones, S. K. Davis and B. C. Dale. 2002. Baird's Sparrow (Ammodramus bairdii). In The Birds of North America, No. 638 (A. Poole and F. Gill's, eds.) The Birds of North America, Inc., Philadelphia, PA. 20 pp.

Hendricks, P., S. Lenard, C. Currier, and J. Carlson. 2007. Grassland bird surveys in north Valley County, Montana: 2001-2006. Report to the Bureau of Land Management, Glasgow Field Office. Montana Natural Heritage Program, Helena, Montana. 19 pp. plus appendices.

Hill, D. P., and L. K. Gould. 1997. Chestnutcollared Longspur (Calcarius ornatus). In The Birds of North America, No. 288 (A. Poole and F. Gill, eds.). The Academy of Natural Sciences, Philadelphia, PA, and the American Ornithologists' Union, Washington, D.C. 20 pp.

Holecheck, J. L., R. D. Pieper, and C. H. Herbel. 2003. Range Management Principles and Practices. Prentice Hall Inc., Upper Saddle River, NJ.

Hutto, R. L., S. M. Pletschet, and P. Hendricks. 1986. A fixed-radius point count method for nonbreeding and breeding season use. Auk 103:593-602.

Johnsgard, P. 2001. Prairie Birds - Fragile Splendor in the Great Plains. University Press of Kansas, Lawrence, KS. 331 pp.

Johnson D. H. and Igl, L. D. 2001. Area requirements of grassland birds: a regional perspective. The Auk 118(1):24-34.

Kantrud, H. A., and R. L. Kologiski. 1982. Effects of soils and grazing on breeding birds of uncultivated upland grasslands of the northern Great Plains. Wildlife Research Report 15, U.S. Department of the Interior, Fish and Wildlife Service. $33 \mathrm{pp}$.
Knapp, A. K., J. M. Blair, J. M. Briggs, S.C. Collins, D. C. Hartnett, L. C. Johnson, and E. G. Towne. 1999. The Keystone Role of Bison in North American Tallgrass Prairie. Bison increase habitat herterogeneity and alter a broad array of plant, community, and ecosystem processes. BioScience 49:39-50.

Knopf, F. L. 1994. Avian assemblages on altered grasslands. Studies in Avian Biology 15:247257.

Lenard, S., J. Carlson, J. Ellis, C. Jones, and C. Tilly. 2003. P. D. Skaar's Montana Bird Distribution, $6^{\text {th }}$ Edition. Montana Audubon, Helena, Montana. 144 pp.

Lenard, S., J. Carlson, P. Hendricks, and C. Currier. 2006. Grassland bird surveys in north Valley County, Montana: progress report. Report to the Bureau of Land Management. Montana Natural Heritage Program, Helena. 22 pp. plus appendices.

Madden, E. M., A. J. Hansen, and R. K. Murphy. 1999. Influence of prescribed fire history on habitat and abundance of passerine birds in northern mixed-grass prairie. Canadian FieldNaturalist 113:627-640.

Madden, E. M., R. K. Murphy, A. J. Hansen, and L. Murray. 2000. Models for guiding management of prairie bird habitat in northwestern North Dakota. American Midland Naturalist 144:377392.

McMaster, D. G., and S. K. Davis. 2001. An evaluation of Canada's Permanent Cover Program: habitat for grassland birds. Journal of Field Ornithology 72:195-210.

Montana Natural Heritage Program and Montana Fish, Wildlife and Parks. 2006. Montana animal species of concern. Helena, MT: Montana Natural Heritage Program \& Montana Department of Fish, Wildlife \& Parks. 16 pp. 
Paige, C., and S. A. Ritter. 1999. Birds in a sagebrush sea: managing sagebrush habitats for bird communities. Partners in Flight Western Working Group, Boise, ID. 47 pp.

Pampush, G. J., and R. G. Anthony. 1993. Nest success, habitat utilization and nest-site selection of Long-billed Curlews in the Columbia River Basin, Oregon. Condor 95:957-967.

Peden, D. G., G. M. Van Dyne, R. W. Rice, and R. M. Hanson. 1974. The trophic ecology of Bison bison L. on shortgrass plains. Journal of Applied Ecology 11:489-497.

Peterjohn, B. G., and J. R. Sauer. 1999. Population status of North American grassland birds from the North American Breeding Bird Survey, 1966-1996. Studies in Avian Biology 19:27-44.

Redmond R. L., M. M. Hart, J. C. Winnie, W. A. Williams, P. C. Thornton, Z. Ma, C. M. Tobalske, M. M. Thornton, K.P. McLaughlin, T. P. Tady, F. B. Fisher, S. W. Running. 1998. The Montana Gap Analysis Project: final report. Unpublished Report. Montana Cooperative Wildlife Research Unit, The University of Montana, Missoula. Montana Land Cover Map. $136 \mathrm{pp}+$ appendices.

Robbins, M. B. and B. C. Dale. 1999. Sprague's Pipit (Anthus spragueii). In The Birds of North America, No. 439 (A. Poole and F. Gill, eds.). The Birds of North America, Inc., Philadelphia, PA. 16 pp.

Saab, V. A., C. E. Bock, T. D. Rich, D. S. Dobkin. 1995. Livestock grazing effects in western North America in Martin, T. E., and D. M. Finch, eds. Ecology and management of Neotropical migratory birds: a synthesis and review of critical issues. Oxford University Press, New York, NY. Pp. 311-353.

Samson F. and F. Knopf. 1994. Prairie conservation in North America. BioScience 44:418-421.
Samson, F. and F. Knopf. 1996. Prairie Conservation - Preserving North America's Most Endangered Ecosystem. Island Press, Washington, D.C. 339 pp.

Sauer, J. R., J. E. Hines, and J. Fallon. 2005. The North American Breeding Bird Survey, Results and Analysis 1966 - 2004. Version 2005.2. USGS Patuxent Wildlife Research Center, Laurel, MD

Schwartz, C. C. and J. E. Ellis. 1981. Feeding ecology and niche separation in some native and domestic ungulates on the shortgrass prairie. Journal of Applied Ecology 18:343-353.

Smith Fargey, K. (ed) 2004. Shared Prairie - Shared Vision.: The Northern Mixed Grass Transboundary Conservation Initiative. Conservation Site Planning Workshop Proceedings and Digital Atlas. Regina, Saskatchewan: Canadian Wildlife Service, Environment Canada.

Swengel, S. R., and A. B. Swengel. 2000. Influences of seasonal and daily timing on detection of grassland birds. Passenger Pigeon 62:225-237.

Vickery, P. D., P. L. Tubaro, J. M. C. Da Silva, B. G. Peterjohn, J. R. Herkert, and R. B. Cavalcanti. 1999. Conservation of grassland birds in the Western Hemisphere. Studies in Avian Biology 19:2-26.

With K. A. 1994. McCown's Longspur (Calcarius mccownii). In the Birds of North America, No. 96 (A. Poole and F. Gills, Eds.). Philadelphia: The Academy of Natural Sciences; Washington, D.C.: The American Ornithologists' Union. 24 pp.

Yackel Adams, A. A., S. K. Skagen, and J. A. Savidge. 2006. Modeling Post-fledging Survival of Lark Buntings in Response to Ecological and Biological Factors. Ecology 87(1): 178-188. 
Appendix A. Global and State Rank Definitions 



\section{Heritage Program Ranks}

The international network of Natural Heritage Programs employs a standardized ranking system to denote global (range-wide) and state status. Species are assigned numeric ranks ranging from 1 to 5 , reflecting the relative degree to which they are "at-risk". Rank definitions are given below. A number of factors are considered in assigning ranks - the number, size and distribution of known "occurrences" or populations, population trends (if known), habitat sensitivity, and threat. Factors in a species' life history that make it especially vulnerable are also considered (e.g., dependence on a specific pollinator).

Global Rank Definitions (NatureServe 2003)

G1 Critically imperiled because of extreme rarity and/or other factors making it highly vulnerable to extinction

G2 Imperiled because of rarity and/or other factors making it vulnerable to extinction

G3 Vulnerable because of rarity or restricted range and/or other factors, even though it may be abundant at some of its locations

G4 Apparently secure, though it may be quite rare in parts of its range, especially at the periphery

G5 Demonstrably secure, though it may be quite rare in parts of its range, especially at the periphery

T1-5 Infraspecific Taxon (trinomial) - The status of infraspecific taxa (subspecies or varieties) are indicated by a "T-rank" following the species' global rank

\section{State Rank Definitions}

S1

S2

S3

S4

S5

At high risk because of extremely limited and potentially declining numbers, extent and/or habitat, making it highly vulnerable to extirpation in the state

S2 At risk because of very limited and potentially declining numbers, extent and/or habitat, making it vulnerable to extirpation in the state

S3 Potentially at risk because of limited and potentially declining numbers, extent and/or habitat, even though it may be abundant in some areas

S4 Uncommon but not rare (although it may be rare in parts of its range), and usually widespread. Apparently not vulnerable in most of its range, but possibly cause for long-term concern Common, widespread, and abundant (although it may be rare in parts of its range). Not vulnerable in most of its range

\section{Combination Ranks}

G\#G\# or S\#S\# Range Rank-A numeric range rank (e.g., G2G3) used to indicate uncertainty about the exact status of a taxon

\section{QuALIFIERS}

NR Not ranked

Questionable taxonomy that may reduce conservation priority-Distinctiveness of this entity as a taxon at the current level is questionable; resolution of this uncertainty may result in change from a species to a subspecies or hybrid, or inclusion of this taxon in another taxon, with the resulting taxon having a lower-priority (numerically higher) conservation status rank 
X

H

U

HYB

?

C

A

Z

P

R

SYN

$*$

B

$\mathrm{N}$

Presumed Extinct - Species believed to be extinct throughout its range. Not located despite intensive searches of historical sites and other appropriate habitat, and virtually no likelihood that it will be rediscovered

Possibly Extinct - Species known from only historical occurrences, but may never-theless still be extant; further searching needed

Unrankable - Species currently unrankable due to lack of information or due to substantially conflicting information about status or trends

Hybrid - Entity not ranked because it represents an interspecific hybrid and not a species

Inexact Numeric Rank-Denotes inexact numeric rank

Captive or Cultivated Only - Species at present is extant only in captivity or cultiva tion, or as a reintroduced population not yet established

Accidental-Species is accidental or casual in Montana, in other words, infrequent and outside usual range. Includes species (usually birds or butterflies) recorded once or only a few times at a location. A few of these species may have bred on the one or two occasions they were recorded

Zero Occurrences - Species is present but lacking practical conservation concern in Montana because there are no definable occurrences, although the taxon is native and appears regularly in Montana

Potential-Potential that species occurs in Montana but no extant or historic occurrences are accepted

Reported-Species reported in Montana but without a basis for either accepting or rejecting the report, or the report not yet reviewed locally. Some of these are very recent discoveries for which the program has not yet received first-hand information; others are old, obscure reports

Synonym - Species reported as occurring in Montana, but the Montana Natural Heritage Program does not recognize the taxon; therefore the species is not assigned a rank

A rank has been assigned and is under review. Contact the Montana Natural Heritage Program for assigned rank

Breeding-Rank refers to the breeding population of the species in Montana

Nonbreeding - Rank refers to the non-breeding population of the species in Montana

Appendix A - 2 


\section{Appendix B. Summary of Point-count Surveys in Northern Blaine and Phillips Counties During 2007}





\section{INTRODUCTION}

We expanded point-count coverage in 2007 to include northern Blaine and Phillips counties (Figure B1) for the purposes of providing baseline data on bird abundances and distributions in this portion of the Malta Field Office-BLM, and using survey methods similar to those employed during grassland bird surveys in north Valley County during 2001-2007. We randomly identified $>200$ starting points in Blaine and Phillips counties on BLM lands, from which three observers ran a total of 71 point-count transects (213 point counts) during 9-29 June.

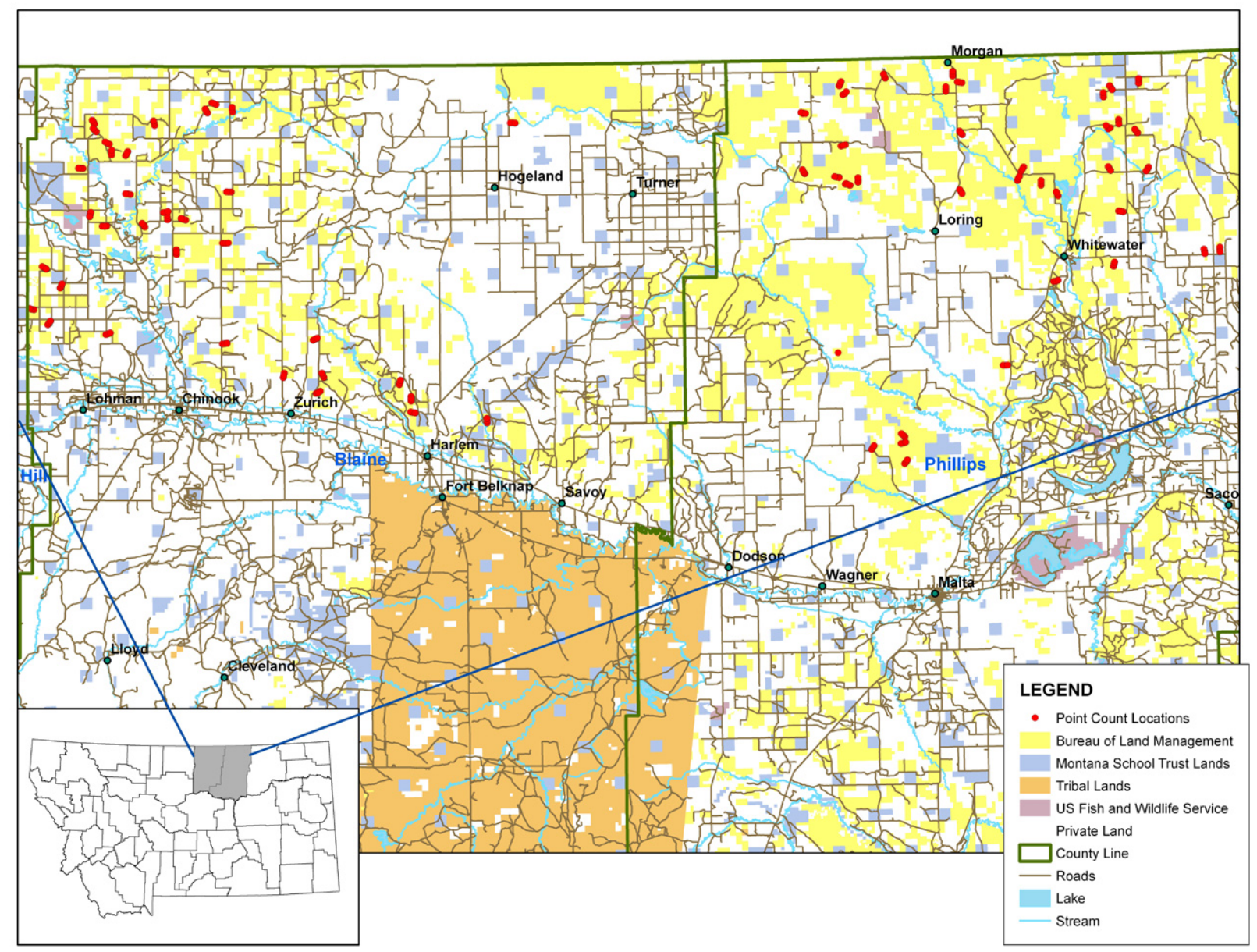

Figure B1. Point count locations in northern Blaine and Phillips counties, Montana in 2007.

Point-count methods were identical for the two areas (Blaine/Phillips and Valley counties); 10 minute counts were conducted at each of 3 fixed-radius points of $100-\mathrm{m}$ radius spaced at least $300 \mathrm{~m}$ apart (thus with $100 \mathrm{~m}$ between the edges of adjacent non-overlapping point-count circles). All counts were initiated between 05:30 and 10:00 MDT. The vegetation data were collected in a modified and simplified form in Blaine and Phillips counties. Instead of collecting vegetation data (height, density index, percent cover) along two perpendicular $25 \mathrm{~m}$ tape transects that intersected at the center of a point count circle (the method in Valley County), we recorded the same types of vegetation data at five 2-m diameter circles: one "mini-plot" located over the center of the point count, and the other four "mini-plots" at random distances between 10 and $100 \mathrm{~m}$ from the center point, one in each of the four quarters of the circle. We recorded 1) maximum vegetation height $(\mathrm{cm})$ within each "mini-plot", 2) the number of times vegetation contacted a vertical rod at four points around the edge of each "mini-plot" at 0-1 dm, 1-2 dm, and $>2 \mathrm{dm}$ heights, 3 ) height of dead vegetation (matted material from previous growing seasons), and 4) the percent cover of bare ground, moss, grass, shrub, and forbs within each "mini-plot." 
Point-count methods were identical for the two areas (Blaine/Phillips and Valley counties); 10 minute counts were conducted at each of 3 fixed-radius points of $100-\mathrm{m}$ radius spaced at least $300 \mathrm{~m}$ apart (thus with $100 \mathrm{~m}$ between the edges of adjacent non-overlapping point-count circles). All counts were initiated between 05:30 and 10:00 MDT. The vegetation data were collected in a modified and simplified form in Blaine and Phillips counties. Instead of collecting vegetation data (height, density index, percent cover) along two perpendicular $25 \mathrm{~m}$ tape transects that intersected at the center of a point count circle (the method in Valley County), we recorded the same types of vegetation data at five 2-m diameter circles: one "mini-plot" located over the center of the point count, and the other four "mini-plots" at random distances between 10 and $100 \mathrm{~m}$ from the center point, one in each of the four quarters of the circle. We recorded 1) maximum vegetation height $(\mathrm{cm})$ within each "mini-plot", 2) the number of times vegetation contacted a vertical rod at four points around the edge of each "mini-plot" at 0-1 dm, 1-2 dm, and $>2 \mathrm{dm}$ heights, 3 ) height of dead vegetation (matted material from previous growing seasons), and 4) the percent cover of bare ground, moss, grass, shrub, and forbs within each "mini-plot."

\section{RESULTS}

During the surveys in 2007, we recorded 22 bird species on our point counts in northern Blaine and Phillips counties. These are listed in Table B1 in order of relative abundance of occurrence (percent of point counts). Seventeen (77.3\%) of the species also were detected on the Valley County point counts every year during 2001-2007. A surprising omission on the Blaine and Phillips counties counts was the Brownheaded Cowbird, which occurred on 4.3-10.1\% of the points in north Valley County during the seven-year period, including $8.2 \%$ of the points in 2007 .

Only three species (Chestnut-collared Longspur, Horned Lark, Western Meadowlark) were detected on $>50 \%$ of the Blaine/Phillips points in 2007, with another three (Sprague's Pipit, McCown's Longspur, Baird's Sparrow) on $25-50 \%$ of the points. Four of these six species (all but Horned Lark and Western Meadowlark) are Montana Species of Concern (SOC). Eight bird Species of Concern were detected on our counts in north Blaine and Phillips counties, and these included all those detected on our north Valley County counts during 2001-2007 with the exception of Bobolink; in addition to those SOC previously listed were Grasshopper Sparrow, Lark Bunting, Brewer's Sparrow, and Long-billed Curlew. Two additional species we detected (Willet and Marbled Godwit) are BLM Sensitive but not Montana SOC.

The relative abundances of the eight SOC birds in north Blaine and Phillips counties were strikingly similar in 2007 to their relative abundances in north Valley County (Table B2). Most abundant in both areas was Chestnut-collared Longspur, followed by Sprague's Pipit; least abundant in both areas was Longbilled Curlew. A ninth SOC bird, Bobolink, was present each year during 2001-2007 on 0.5-5.3\% (3.4\% in 2007) of the north Valley County counts, but was absent on our point counts in north Blaine and Phillips counties. 
Table B1. Bird species detected on point counts in north Blaine and Phillips counties in June 2007; Montana Species of Concern are in bold. Total point counts $=213$. Species are listed in order of relative abundance.

\begin{tabular}{|l|c|c|}
\hline \multicolumn{1}{|c|}{ Species } & \multicolumn{1}{|c|}{$\begin{array}{c}\text { Number of points } \\
\text { on which detected }\end{array}$} & $\begin{array}{c}\text { Percentage of points } \\
\text { on which detected }\end{array}$ \\
\hline Chestnut-collared Longspur & 192 & 90.1 \\
\hline Horned Lark & 187 & 87.8 \\
\hline Western Meadowlark & 108 & 50.7 \\
\hline Sprague's Pipit & 100 & 46.9 \\
\hline McCown's Longspur & 81 & 38.0 \\
\hline Baird's Sparrow & 57 & 26.8 \\
\hline Vesper Sparrow & 37 & 17.4 \\
\hline Grasshopper Sparrow & 25 & 11.7 \\
\hline Savannah Sparrow & 17 & 8.0 \\
\hline Lark Bunting & 13 & 6.1 \\
\hline Brewer's Sparrow & 12 & 5.6 \\
\hline Marbled Godwit & 7 & 3.3 \\
\hline Willet & 6 & 2.8 \\
\hline Killdeer & 5 & 2.3 \\
\hline Long-billed Curlew & 4 & 1.9 \\
\hline Brewer's Blackbird & 4 & 1.9 \\
\hline Clay-colored Sparrow & 3 & 1.4 \\
\hline Mallard & 1 & 0.5 \\
\hline Lesser Scaup & 1 & 0.5 \\
\hline Sharp-tailed Grouse & 1 & 0.5 \\
\hline American Avocet & 1 & 0.5 \\
\hline Cliff Swallow & 1 & 0.5 \\
\hline
\end{tabular}

Table B2. Comparison of the relative abundances (percent of point counts) for eight Montana Species of Concern birds in north Blaine and Phillips counties and north Valley County that were detected on point counts in 2007. Numbers of point counts are in parentheses.

\begin{tabular}{|l|c|c|}
\hline \multicolumn{1}{|c|}{ Species } & Blaine/Phillips (213) & Valley (207) \\
\hline Long-billed Curlew & 1.9 & 1.9 \\
\hline Sprague's Pipit & 46.9 & 58.0 \\
\hline Brewer's Sparrow & 5.6 & 5.8 \\
\hline Lark Bunting & 6.1 & 13.0 \\
\hline Grasshopper Sparrow & 11.7 & 12.6 \\
\hline Baird's Sparrow & 26.8 & 46.4 \\
\hline McCown's Longspur & 38.0 & 20.3 \\
\hline Chestnut-collared Longspur & 90.1 & 89.9 \\
\hline
\end{tabular}

In 2007, Sprague's Pipit and Baird's Sparrow were more abundant in Valley County while McCown's Longspur was more abundant in Blaine and Phillips counties (Table B2, Figure B2). These patterns in relative abundance probably reflect differences in vegetation structure in the two areas. Average maximum vegetation height in 2007 in north Valley County $(47.2 \pm 7.3 \mathrm{~cm})$ was slightly but significantly taller (Two-sample t-test: $t=-4.65, \mathrm{P}<0.0001)$ than in north Blaine and Phillips counties $(43.8 \pm 7.7 \mathrm{~cm})$. It is possible that this difference would be more substantial in other years; 2007 was a year of unusually heavy spring (April and May) precipitation across the region (Figure B3). 

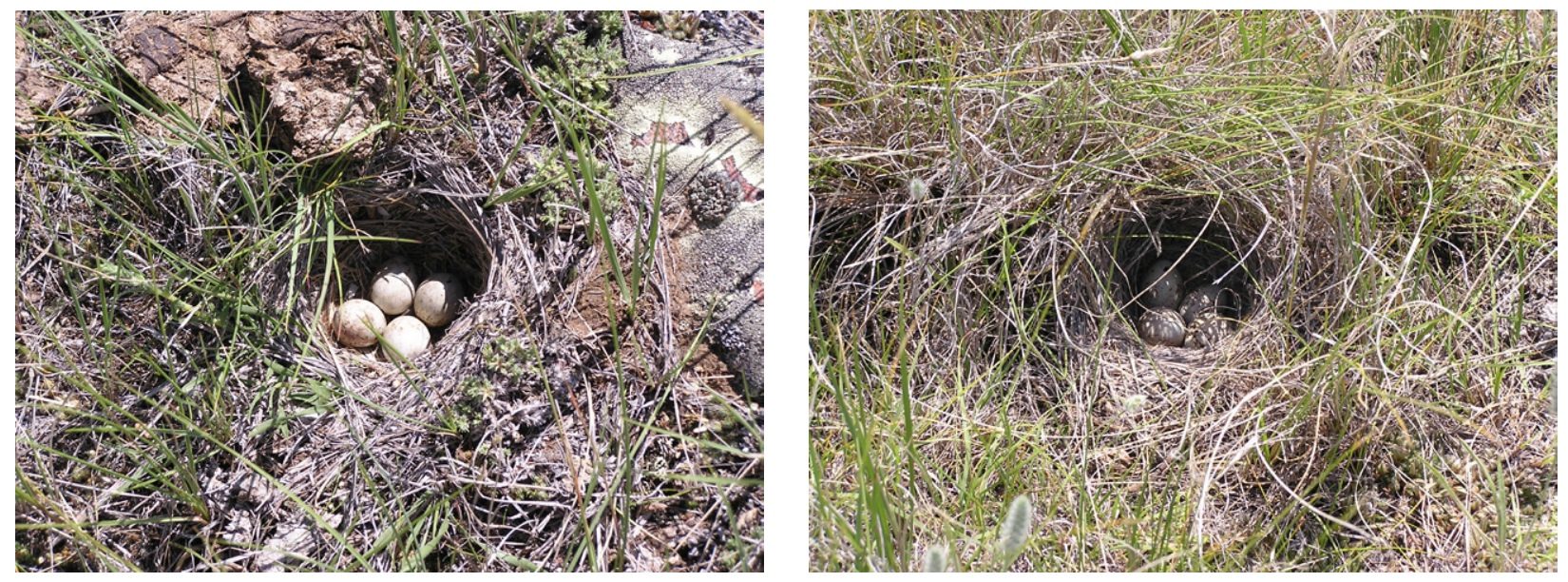

Figure B2. McCown's Longspur nests. Note difference in vegetation structure around each nest.
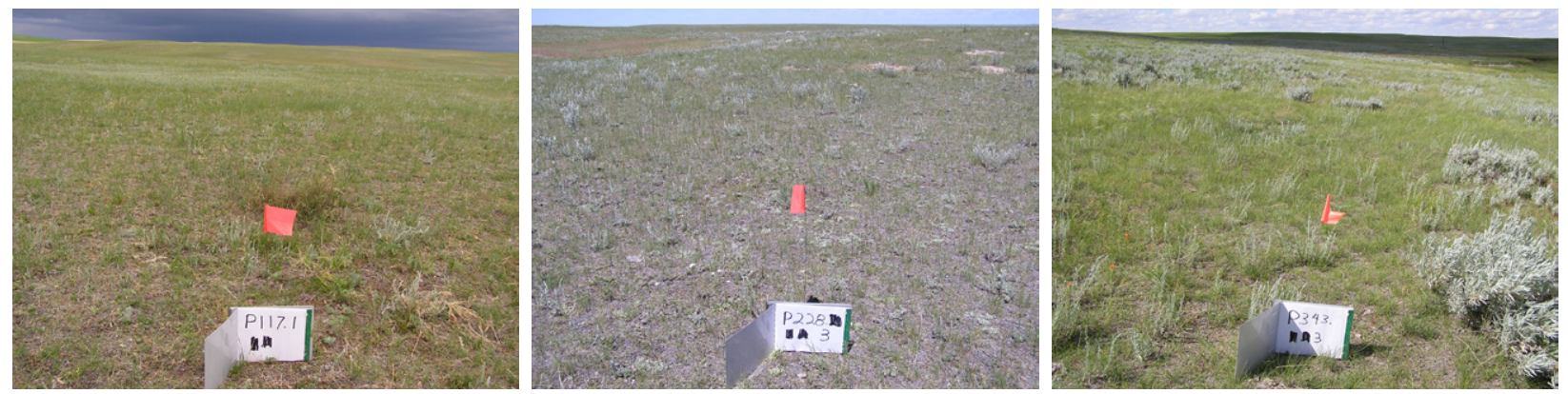

Figure B3. June 2007 vegetation on three count points $(117.1,228.3,343.3)$ in north Phillips County.

During 2001-2007 in north Valley County, Sprague's Pipit and Baird's Sparrow tended to occupy sites with significantly taller (Kruskal-Wallis ANOVA pair-wise comparisons, $\mathrm{P}<0.05$ ) grassland vegetation $(40.8 \pm 9.2 \mathrm{~cm}$ and $43.7 \pm 9.8 \mathrm{~cm}$, respectively), than McCown's Longspur $(37.4 \pm 8.2 \mathrm{~cm})$, which is also consistent with their patterns in distribution across the northeastern Montana landscape. Lark Bunting, another species occurring on a greater percentage of point counts in Valley County, also tended to occur on points where grassland vegetation was significantly $(\mathrm{P}<0.05)$ taller $(41.2 \pm 10.9 \mathrm{~cm})$ than those occupied by McCown's Longspur during 2001-2007, but it is sometimes nomadic, and greater numbers in Valley County could as well be a function of spatial location relative to over-wintering areas. Assuming the tendencies in vegetation structure associations we saw by the respective species in north Valley County apply across all three counties, then that further supports the suggestion that spatial differences in relative abundance of SOC birds is tied to vegetation structure.

\section{Discussion}

BLM lands in northern Blaine and Phillips counties continue to support a diversity of breeding birds, including most or all of those we detected every year of our study to the east in north Valley County. Bobolink was the only SOC bird present in Valley County every year but not detected on our Blaine and Phillips counties points in 2007. However, even in Valley County Bobolink occurred on very few points (no more than 5.3\% in seven years of survey), so we may have missed them if it was limited to just a few sites with taller and denser vegetation, which is quite possible. That aside, our survey results indicate that the public lands administered by the BLM in the north half of Blaine and Phillips counties provide a mosaic of grassland conditions necessary to support breeding populations of SOC birds that use sites with relatively short grass of low density near the ground, to other species associated with tall and dense grass. 
The absence of Brown-headed Cowbird on our points in Blaine and Phillips counties may be tied to a larger expanse of agricultural lands within the region, but the reasons for their absence remain unknown.

As our seven-year study in north Valley County shows, vegetation conditions can vary significantly from year-to-year, so extrapolating results or patterns from a single year of counts to multiple years would be a mistake. The primary conclusions that can be made from our single year of point counts are 1) a large number of breeding SOC grassland birds that deserve additional conservation attention occur in northern Blaine and Phillips counties, and 2) they comprise a significant proportion, in terms of species richness and relative abundance, of the total grassland avifauna on public lands. 

Appendix C. Predictive Distribution Models for Grassland BIRDS 



\section{INTRODUCTION}

Despite a proliferation of bird point count monitoring stations across Montana and the Malta Field Office of the BLM in recent years, baseline coverage in some areas is still poor. Furthermore, existing predicted distribution models for birds and other vertebrates is limited to deductive or "rule based" models that do not make use of the existing positive data available in statewide databases. Predicted distribution models were therefore created for 11 grassland bird species in order to: (1) better understand the potential ranges of the species in Montana and the Malta Field Office of the BLM; (2) identify areas of predicted distribution that should be targeted for future surveys; (3) determine which environmental variables have the highest predictive association with the presence of each species; and (4) identify spatial patterns in the suitability of habitat for these species.

\section{Modeling Approach}

Program Maxent Version 2.3 (Jaynes 1957; Miroslav et al. 2004, 2005, 2007; Phillips et al. 2004, 2006; www.cs.princeton.edu/ schapire/maxent/) was used to create statewide predicted distribution models based on locations of observations for individual species in the statewide Point Observation Database and 6 continuous (elevation, slope, landsurface curvature, annual precipitation, maximum July temperature, minimum January temperature) and 5 categorical (aspect, geology, 1992 National Land Cover Data, soil temperature class, STATSGO soils) environmental layers. Observation locations for each species were input in comma delimited format and environmental layers were fitted to $90 \mathrm{~m}$ grid cell pixels in ASCII format. Both species observation locations and environmental layers were projected to North American Datum 1983 in Montana State Plane.

Program Maxent Version 2.3 (Jaynes 1957; Miroslav et al. 2004, 2005, 2007; Phillips et al. 2004, 2006; www.cs.princeton.edu/ schapire/maxent/) generates probability distributions for all environmental layers over all pixels that are associated with observations of the species. These environmental "features" are used to constrain the probability distribution computed to predict the statewide distribution of species so that estimated distributions match characteristics of the empirical distributions resulting from the positive data. Depending on the amount of positive data available the estimated distribution is automatically constrained to match the empirical average (linear feature), average and variance (quadratic feature), covariance (product feature), proportional occurrence (threshold feature), or average below and constant above a certain point (hinge feature). Categorical environmental variables have a discrete feature for every possible value of the variable so that the estimated distributions have the same proportional representation of each categorical value. In practice Maxent 2.3 avoids overfitting of models to the training data by "regularizing" or relaxing the feature constraints so that feature expectations only have to be close to the empirical distributions rather than exactly equal to them. A regularization parameter can be entered in Maxent 2.3 in order to delineate just how close of a fit is needed between empirical features and estimated distributions.

Maxent Version 2.3 makes use of the Gibbs distribution which takes the form:

$\mathrm{P}(\mathrm{x})=\exp (\mathrm{c} 1 * \mathrm{f1}(\mathrm{x})+\mathrm{c} 2 * \mathrm{f} 2(\mathrm{x})+\mathrm{c} 3 * \mathrm{f} 3(\mathrm{x}) \ldots) / \mathrm{Z}$

Where $\mathrm{c} 1, \mathrm{c} 2, \mathrm{c} 3, \ldots$ are weighted constants, $\mathrm{f} 1, \mathrm{f} 2, \mathrm{f} 3, \ldots$ are the constrained environmental features, and $\mathrm{Z}$ is a scaling constant that ensures that $\mathrm{P}$ sums to 1 over all grid cells. The Maxent 2.3 algorithm is guaranteed to converge to values of $c 1, c 2, c 3, \ldots$ that give the unique optimum distribution $\mathrm{P}$, and, therefore, the outputs are deterministic. The program begins with a uniform distribution (the distribution with maximum entropy) and successively modifies each weighted constant on each iteration until either the change in the "gain" (the log of the number of grid cells minus the average of the negative log probabilities of the 
sample locations) falls below a set threshold or a set maximum number of iterations are performed. Thus, the Maxent 2.3 algorithm finds the most uniform distribution (the one with the maximum entropy) subject to the constraints of the environmental features. Maxent 2.3 can use every grid cell that has values for all the environmental variables to calculate the distribution. However, because there are a large number of 90-m grid cells for Montana (10,204 columns and 5,892 rows), and the modeling performance of Maxent 2.3 does not improve significantly with very large numbers of pixels, 60,000 background pixels (added to those with positive species data) were used to represent the variety of environmental conditions present in the data. This limitation also serves to generalize or "regularize" the model to make sure that it is not overfit to the limited number of locations where species were observed.

The main output is in the form of a cumulative function with grid cells having values of 100 representing the most suitable habitat (best fit to the positive data) while those with values closer to 0 are less suitable habitat (worst fit to the positive data). Note that Maxent Version 2.3 output is not interpreted as probability of occupancy. Other standard model output includes: (1) an evaluation of omission error rates for training and test data as a function of the cumulative threshold and overall predicted area; (2) a Receiver Operating Characteristic (ROC) curve which evaluates the overall predictive power of the model; (3) a table of potential thresholds which could be used to categorize the continuous output into a binomial predicted or not predicted output; (4) a statewide map showing the continuous probability function as well as the training and test data points; (5) response curves for individual environmental variables showing how each affects the output while all other environmental variables are held constant at their average sample value; and (6) jackknife charts showing the relative importance of all environmental variables as a function of the fit of the model to the data with their exclusion or sole inclusion in the model.

Below we provide an overview of bird observations used in the modeling effort as well as comments on the model output. We then describe the environmental input layers and provide complete model output for individual species. 
Table C1. Overview of Bird Observations Used in Modeling Effort. The predicted distributions of 11 grassland bird Species of Concern on the Malta Field Office of the BLM were modeled. The table below summarizes observation records for these species, the number of records used to train the models, and the number of records used to test the models. In general models performed well in terms of omission and commission error rates where positive data is present in a region. However, there is reason to believe that the models may perform less well in regions that lack surveys (i.e., they are probably over fit to regions that have positive data from surveys). All model output should be regarded as a first iteration with additional modeling needed (e.g., the exact characteristics of the soils and geology classes need to be identified when these variables are found to be driving the models).

\begin{tabular}{|c|c|c|c|c|c|}
\hline $\begin{array}{c}\text { Scientific Name } \\
\text { (Bold = Species of Concern) }\end{array}$ & $\begin{array}{l}\text { G Rank / } \\
\text { S Rank }\end{array}$ & $\begin{array}{c}\text { Total } \\
\text { No. } \\
\text { Records }\end{array}$ & $\begin{array}{c}\text { No. Records } \\
\leq 400 \text { Meters } \\
\text { Locational } \\
\text { Uncertainty }\end{array}$ & $\begin{array}{c}\text { No. Spatially } \\
\text { Unique Records } \\
\text { Used to Train } \\
\text { Model } \\
\end{array}$ & $\begin{array}{c}\text { No. Spatially } \\
\text { Unique Records } \\
\text { Used to Test } \\
\text { Model } \\
\end{array}$ \\
\hline $\begin{array}{l}\text { Greater Sage Grouse } \\
\text { (Centrocercus urophasianus) }\end{array}$ & G4/S3 & 7896 & 7181 & 1177 & 392 \\
\hline $\begin{array}{l}\text { Mountain Plover } \\
\text { (Charadrius montanus) }\end{array}$ & $\mathrm{G} 2 / \mathrm{S} 2 \mathrm{~B}$ & 3244 & 467 & 187 & 62 \\
\hline $\begin{array}{l}\text { Long-billed Curlew } \\
\text { (Numenius americanus) }\end{array}$ & G5/S2B & 860 & 510 & 279 & 92 \\
\hline $\begin{array}{l}\text { Sprague's Pipit } \\
\text { (Anthus spragueii) }\end{array}$ & $\mathrm{G} 4 / \mathrm{S} 2 \mathrm{~B}$ & 2007 & 1418 & 412 & 137 \\
\hline $\begin{array}{l}\text { Brewer's Sparrow } \\
\text { (Spizella breweri) }\end{array}$ & G5/S2B & 1670 & 1327 & 633 & 210 \\
\hline $\begin{array}{l}\text { Lark Bunting } \\
\text { (Calamospiza melanocorys) }\end{array}$ & G5/S3B & 1545 & 1185 & 657 & 218 \\
\hline $\begin{array}{l}\text { Baird's Sparrow } \\
\text { (Ammodramus bairdii) }\end{array}$ & G4/S2B & 1737 & 954 & 335 & 112 \\
\hline $\begin{array}{l}\text { Grasshopper Sparrow } \\
\text { (Ammodramus savannarum) }\end{array}$ & G5/S3B & 996 & 643 & 356 & 119 \\
\hline $\begin{array}{l}\text { McCown's Longspur } \\
\text { (Calcarius ornatus) }\end{array}$ & G4/S2B & 684 & 487 & 209 & 69 \\
\hline $\begin{array}{l}\text { Chestnut-collared Longspur } \\
\text { (Calcarius ornatus) }\end{array}$ & G5/S3B & 2628 & 1739 & 519 & 173 \\
\hline $\begin{array}{l}\text { Bobolink } \\
\text { (Colichonyx oryzivorus) }\end{array}$ & G5/S2B & 398 & 135 & 80 & 26 \\
\hline
\end{tabular}




\section{DESCRIPTIONS OF ENVIRONMENTAL INPUT LAYERS}

Input environmental layers consisted of 6 continuous (elevation, slope, curvature of land surface, annual precipitation, maximum July temperature, minimum January temperature) and 5 categorical (aspect, geology, 1992 National Land Cover Data, soil temperature class, STATSGO soils) variables. These layers were tiled together, resampled, and converted to a statewide coverage of $90 \mathrm{~m}$ grid cells in ASCII format with 10,204 columns and 5,892 rows projected to North American Datum 1983 in Montana State Plane. Each source environmental layer is described below and, where appropriate, links to metadata are provided.

\section{Aspect (Categorical)}

Calculated using the Aspect function in ArcMap 9.2 Spatial Analyst from the 10-m National Elevation Dataset (NED) and resampled to $90 \mathrm{~m}$. See description of the elevation layer and the associated NED metadata link below. A brief summary of raster cell value descriptions for grid bearing values follows below.

$$
\begin{aligned}
& 0=\text { Flat } \\
& 1=\text { North }(337.5-22.5) \\
& 2=\text { Northeast }(22.5-67.5) \\
& 3=\text { East }(67.5-112.5) \\
& 4=\text { Southeast }(112.5-157.5) \\
& 5=\text { South }(157.5-202.5) \\
& 6=\text { Southwest }(202.5-247.5) \\
& 7=\text { West }(247.5-292.5) \\
& 8=\text { Northwest }(292.5-337.5)
\end{aligned}
$$

\section{Curvature of Land Surface (Continuous)}

Calculated using the Curvature function in ArcMap 9.2 Spatial Analyst from the 90-m resampled grid resulting from the 10-m National Elevation Dataset (NED). See description of the elevation layer and the associated NED metadata link below. Values are continuous from -50 (concave land surface) to +50 (convex land surface).

\section{Elevation (Continuous)}

The National Elevation Dataset (NED) is a $1 / 3$ arc-second (10-m) raster grid of decimal meter values assembled by the U.S. Geological Survey. Metadata on the 1/3 arc-second (10-m) NED is at: http://seamless.usgs.gov/products/3arc.php

\section{Geology (Categorical)}

A polygonal coverage of surficial geology available in a mixture of 1:100,000 and 1:250,000 scales from the Montana State Geologic Mapping Program at the Montana Bureau of Mines and Geology. Metadata on the state geology map is at: http://www.mbmg.mtech.edu/gmr/gmr-statemap.asp

\section{Maximum July Temperature (Continuous)}

A polygonal coverage of estimated average maximum daily temperatures for July in degrees Fahrenheit, for the climatological period 1971-2000. Estimates are based on Parameter-elevation Regressions on Independent Slopes Model (PRISM) derived raster data which uses known point temperature data and a digital elevation model (DEM) to generate gridded estimates of annual, monthly and event-based climatic parameters. General information on the underlying PRISM data and the source data itself can be down- 
loaded from the Oregon Climate Service website at: http://www.ocs.orst.edu/prism/. The Montana data reprojected to Montana State Plane and resampled to a resolution of $600 \mathrm{~m}$ representing 33 temperature ranges in degrees Fahrenheit is available at: http://nris.mt.gov/nsdi/nris/tmax71 00.html

\section{Minimum January Temperature (Continuous)}

A polygonal coverage of estimated average minimum daily temperatures for January in degrees Fahrenheit, for the climatological period 1971-2000. Estimates are based on Parameter-elevation Regressions on Independent Slopes Model (PRISM) derived raster data which uses known point temperature data and a digital elevation model (DEM) to generate gridded estimates of annual, monthly and event-based climatic parameters. General information on the underlying PRISM data and the source data itself can be downloaded from the Oregon Climate Service website at: http://www.ocs.orst.edu/prism/. The Montana data reprojected to Montana State Plane and resampled to a resolution of $600 \mathrm{~m}$ representing 33 temperature ranges in degrees Fahrenheit is available at: http://nris.mt.gov/nsdi/nris/tmin71_00.html

\section{National Landcover Data (Categorical)}

The 1992 National Land Cover Data Set is based on 30-m Landsat Thematic Mapper imagery. A brief summary of raster cell value descriptions follows below. Metadata on this layer can be found at: http:// nris.mt.gov/nsdi/nris/nlcdgrid.html

11 Open Water

12 Perennial Ice/Snow

$21 \quad$ Low Intensity Residential

$22 \quad$ High Intensity Residential

$23 \quad$ Commercial/Industrial/Transportation

$31 \quad$ Bare Rock/Sand/Clay

32 Quarries/Strip Mines/Gravel Pits

33 Transitional

41 Deciduous Forest

$42 \quad$ Evergreen Forest

43 Mixed Forest

$51 \quad$ Shrubland

61 Orchards/Vineyards/Other

71 Grasslands/Herbaceous

$81 \quad$ Pasture/Hay

82 Row Crops

83 Small Grains

$84 \quad$ Fallow

85 Urban/Recreational Grasses

$91 \quad$ Woody Wetlands

92 Emergent Herbaceous Wetlands

\section{Annual Precipitation (Continuous)}

A polygonal coverage of annual precipitation in inches for the climatological period 1961-1990 based on source data from the National Weather Service Cooperative stations, Natural Resources Conservation Service SNOTEL stations, and local networks. Metadata on this layer can be found at: http://nris.mt.gov/ nsdi/nris/precip.html 


\section{STATSGO Soils (Categorical)}

State Soil Geographic data (STATSGO) is a polygonal coverage of general soil associations developed by the National Cooperative Soil Survey. The soil maps for STATSGO are compiled by generalizing more detailed soil survey maps. Map unit composition for a STATSGO map is determined by transecting or sampling areas and expanding the data statistically to characterize the whole map unit. Therefore, map units depict the dominant soils making up the landscape and often contain dissimilar soil types. The approximate minimum area delineated is 625 hectares (1,544 acres). Background information and metadata on STATSGO is available at: http://nris.mt.gov/nsdi/statsgo.pdf, http://nris.mt.gov/nsdi/nris/SS19.html, and http://dbwww.essc.psu.edu/doc/statsgo/statsgo_info.html. Definitions for the 694 map units used in the input can be downloaded as .dbf files along with a STATSGO shapefile for Montana at: http://nris. mt.gov/gis/gisdatalib/gisDataList.aspx?datagroup=statewide-regional\&searchTerms $=$ statsgo

\section{Slope (Continuous)}

Percent slope (rise over run multiplied by 100) calculated using the Slope function in ArcMap 9.2 Spatial Analyst from the 10-m National Elevation Dataset (NED) and resampled to $90 \mathrm{~m}$. See description of the elevation layer and the associated NED metadata link above.

\section{Soil Temperature Regime (Categorical)}

A generalized polygonal coverage of soil temperature regimes. A brief summary of raster cell value descriptions follows below. A glossary of relevant soil terminology can be found at: https://www.soils. org/sssagloss/. Metadata on this layer can be found at: http://soils.usda.gov/use/worldsoils/mapindex/str. $\underline{\mathrm{html}}$

$\begin{array}{ll}1 & \text { Cryic/Udic } \\ 2 & \text { Frigid/Udic } \\ 3 & \text { Frigid/Typic Ustic } \\ 4 & \text { Cryic/Typic Ustic } \\ 5 & \text { Frigid/Aridic Ustic } \\ 6 & \text { Frigid Aquic } \\ 7 & \text { Frigid/Typic Xeric } \\ 8 & \text { Water } \\ 9 & \text { Cryic/Typic Xeric } \\ 10 & \text { Cryic/Aridic Ustic } \\ 11 & \text { Mesic/Ustic Aridic } \\ 12 & \text { Cryic/Udic Ustic }\end{array}$


REFERENCES (most can be downloaded at: www.cs.princeton.edu/ schapire/maxent/)

Jaynes, E. T. 1957. Information theory and statistical mechanics. Physics Reviews 106:620-630.

Miroslav, D., S. J. Phillips, and R. E. Schapire. 2004. Performance guarantees for regularized maximum entropy density estimation. Proceedings of the Seventeenth Annual Conference on Computational Learning Theory pp. 472-486.

Miroslav, D., S. J. Phillips, and R. E. Schapire. 2007. Maximum entropy density estimation with generalized regularization and an application to species distribution modeling. Journal of Machine Learning Research 8 (2007): 1217-1260.

Miroslav, D., R. E. Schapire, and S. J. Phillips. 2005. Correcting sample selection bias in maximum entropy density estimation. pp 323-330. In: Advances in Neural Information Processing Systems 18. MIT Press.

Phillips, S. J., R. P. Anderson, and R. E. Schapire. 2006. Maximum entropy modeling of species geographic distributions. Ecological Modelling 190(3-4):231-259.

Phillips, S. J., D. Miroslav, and R. E. Schapire. 2004. A maximum entropy approach to species distribution modeling. Proceedings of the Twenty-First International Conference on Machine Learning pp. 655-662. 


\section{Model Output}

Map and chart outputs for the predicted modeling effort are included below for each of the 11 grassland bird Species of Concern that were modeled. The individual species models highlight the relative importance of Valley, Phillips, and Blaine Counties to the conservation of these grassland bird Species of Concern in Montana. This is further highlighted in the composite image of predicted distributions for all species shown below.

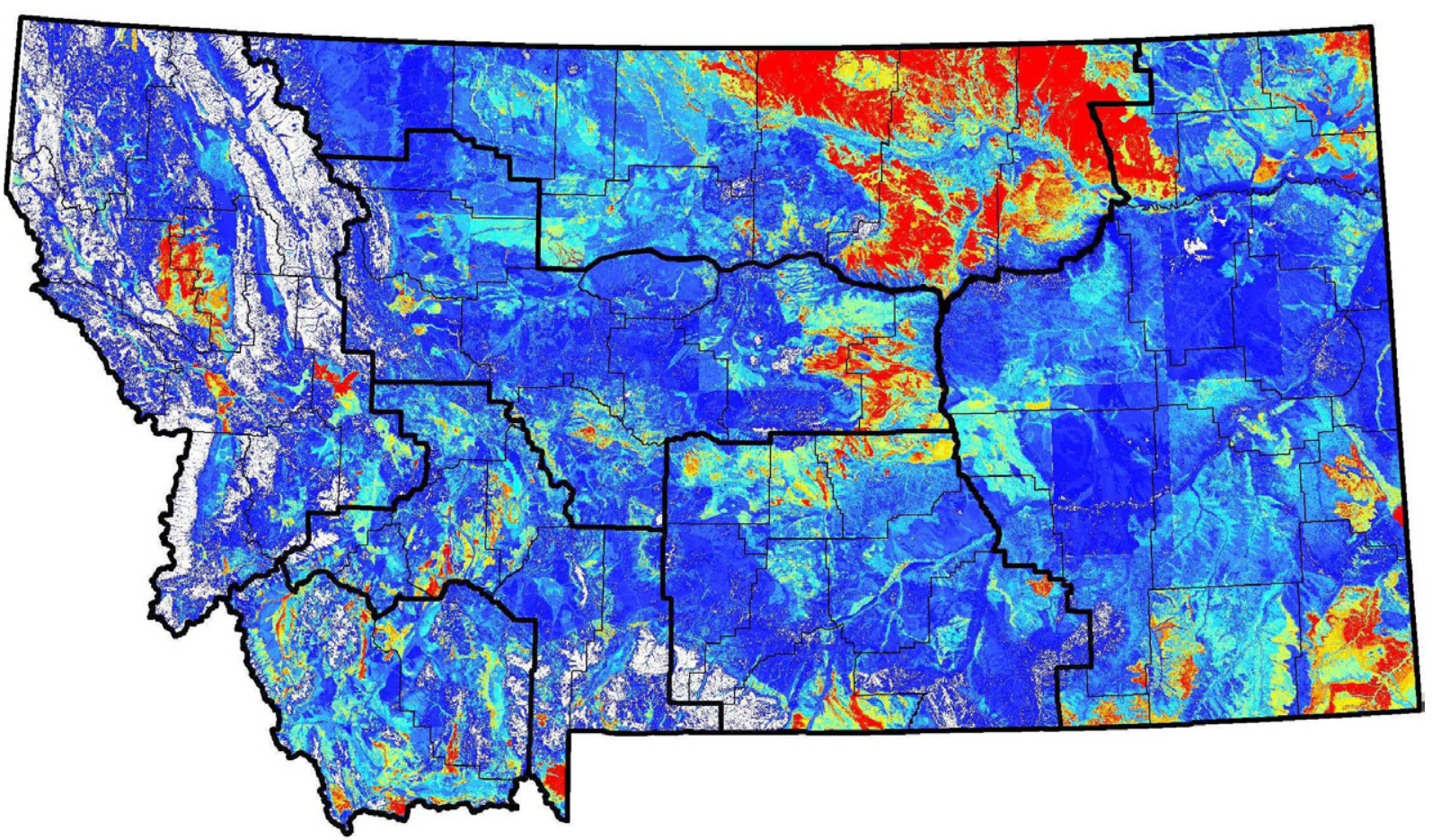

Figure C1. Composite Image of Predicted Distributions for 11 Grassland Bird Species of Concern. The hot-to-cold color map indicates the composite suitability of each grid cell for all 11 grassland bird Species of Concern as a function of the environmental variables at that grid cell. Hotter colors indicate areas that are predicted to have more suitable habitat for all 11 species. BLM Field Office boundaries and county lines are included for reference. 


\section{Greater Sage-Grouse (Centrocercus urophasianus)}

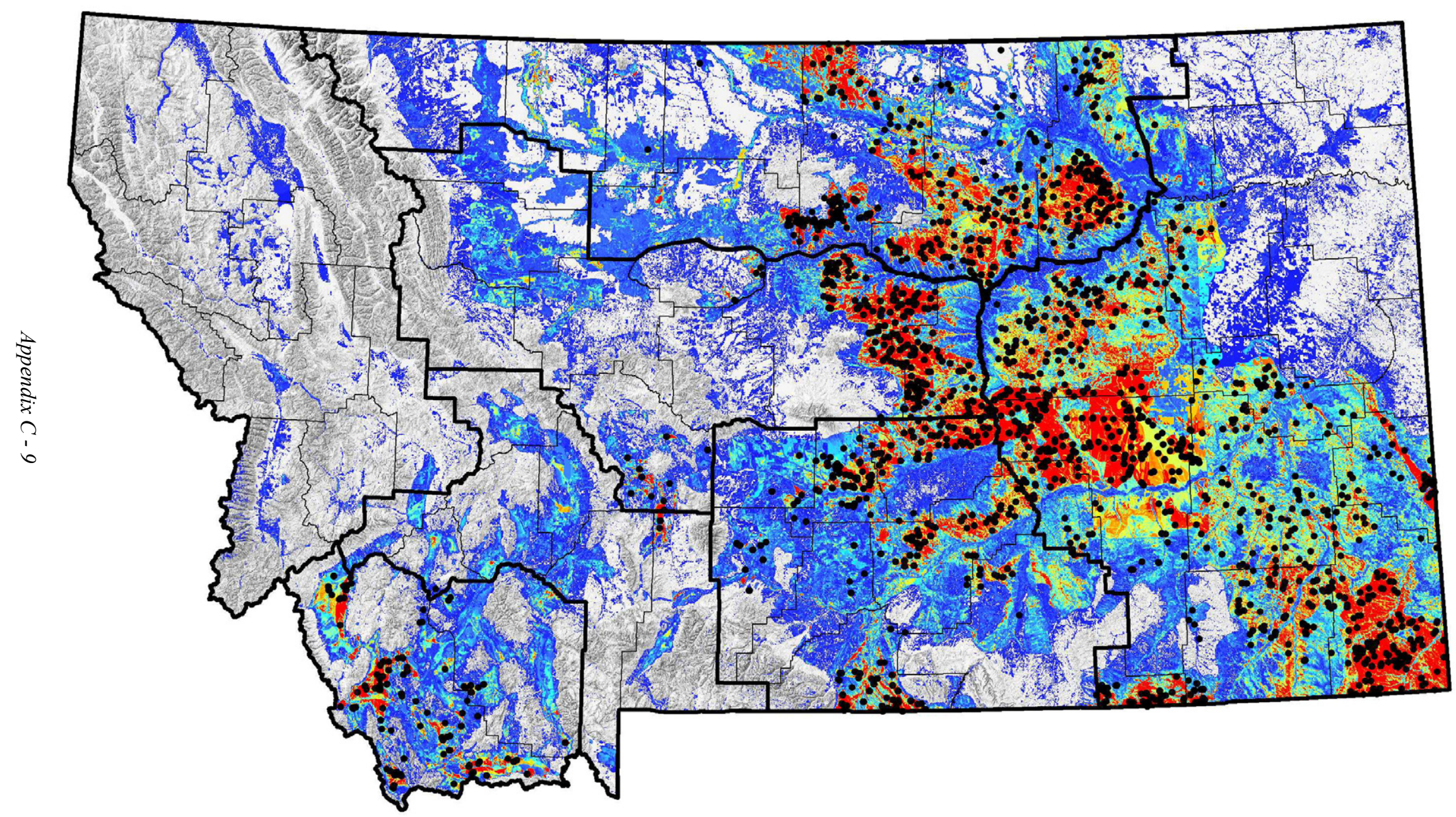

Figure C2. The hot-to-cold color map indicates the suitability of each grid cell as a function of the environmental variables at that grid cell. Hotter colors indicate areas that are predicted to have more suitable habitat for the species. Black dots are positive data used to build the model. A shaded relief map, BLM Field Office boundaries, and county lines are included for reference. 


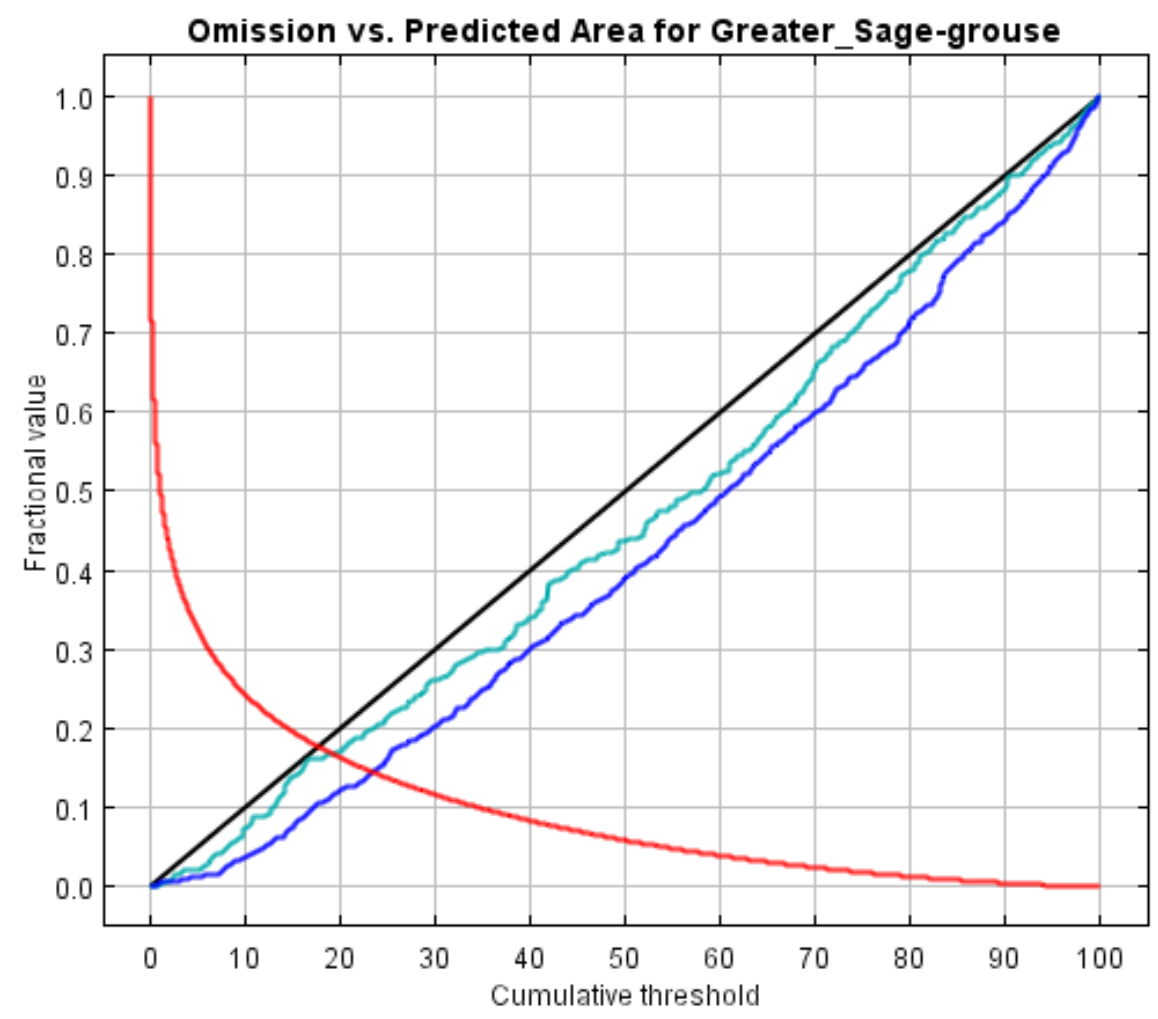

Fraction of background predicted Omission on training samples Omission on test samples Predicted omission $\mathbf{a}$

Figure C3. An evaluation of omission error rates for training (dark blue line) and test (light blue line) data as a function of the cumulative threshold and overall predicted area. The red line indicates the overall fraction of the map area fitting each value of the cumulative threshold. The black line is the predicted omission rate for each cumulative threshold. 


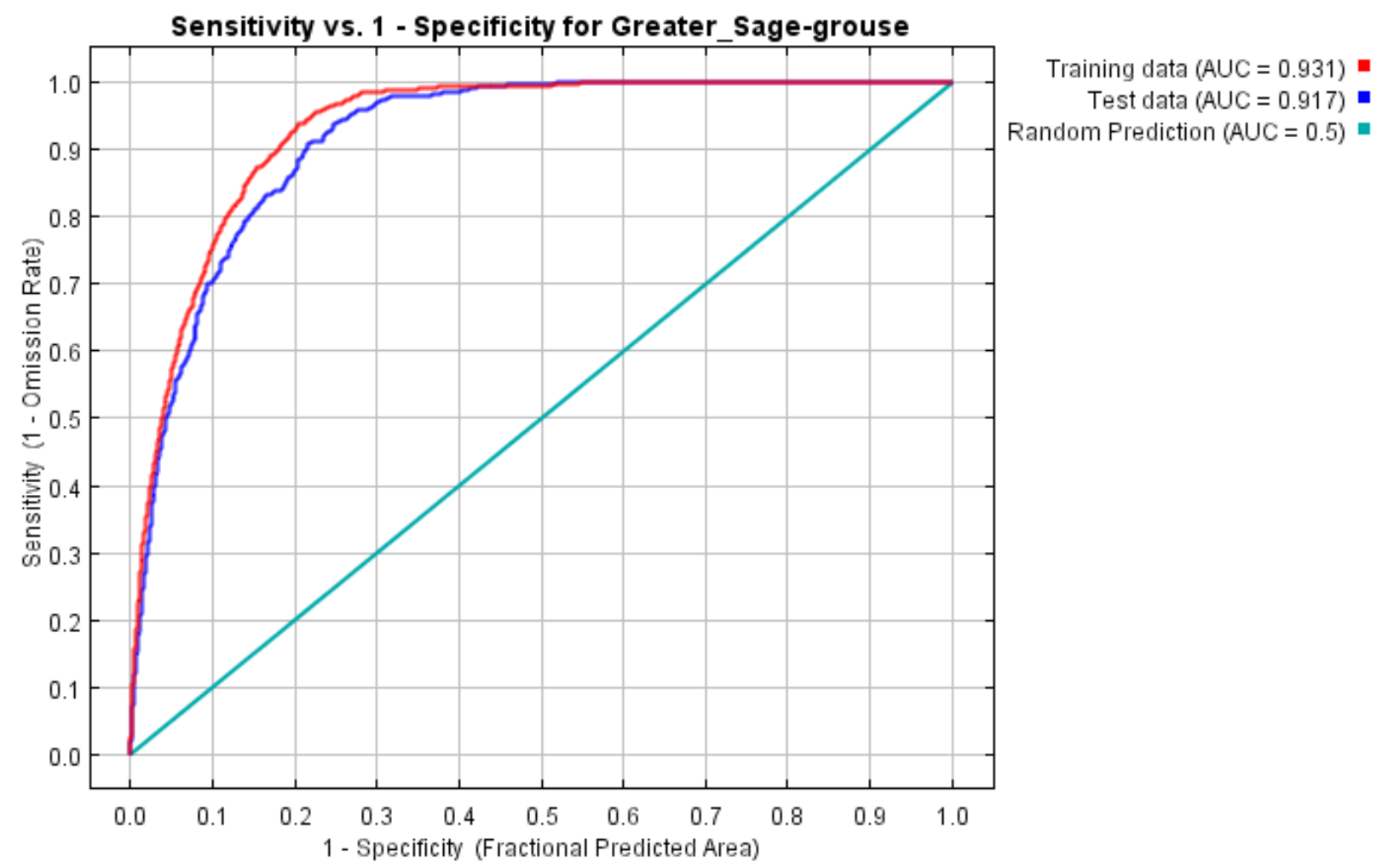

Figure C4. Receiver Operating Characteristic (ROC) curve evaluating the overall predictive power of the model with the Area Under the Curve (AUC). The AUC value indicates that when two random locations are chosen the model has that probability of assigning a higher cumulative threshold value to the location with more suitable habitat. The light blue line indicates how a neutral or random model would perform (i.e., it only has a 50\% probability of assigning a higher cumulative threshold value to a random location with more suitable habitat than a random location with less suitable habitat). The further toward the top left of the graph the training (red) and test (blue) data lines are, the better the model is at predicting the presences contained in the training data. Sensitivity (plotted on the y-axis) is the proportion of positive locations that were correctly classified by the model. Sensitivity is also known as the true positive rate and can be thought of as the degree of absence of omission errors. Specificity is the proportion of random locations chosen from the background (these pseudo-absences are used instead of true negative locations) that were correctly classified by the model as negative. One minus the Specificity (plotted on the $x$-axis) is known as the false positive rate and represents the commission error rate. 

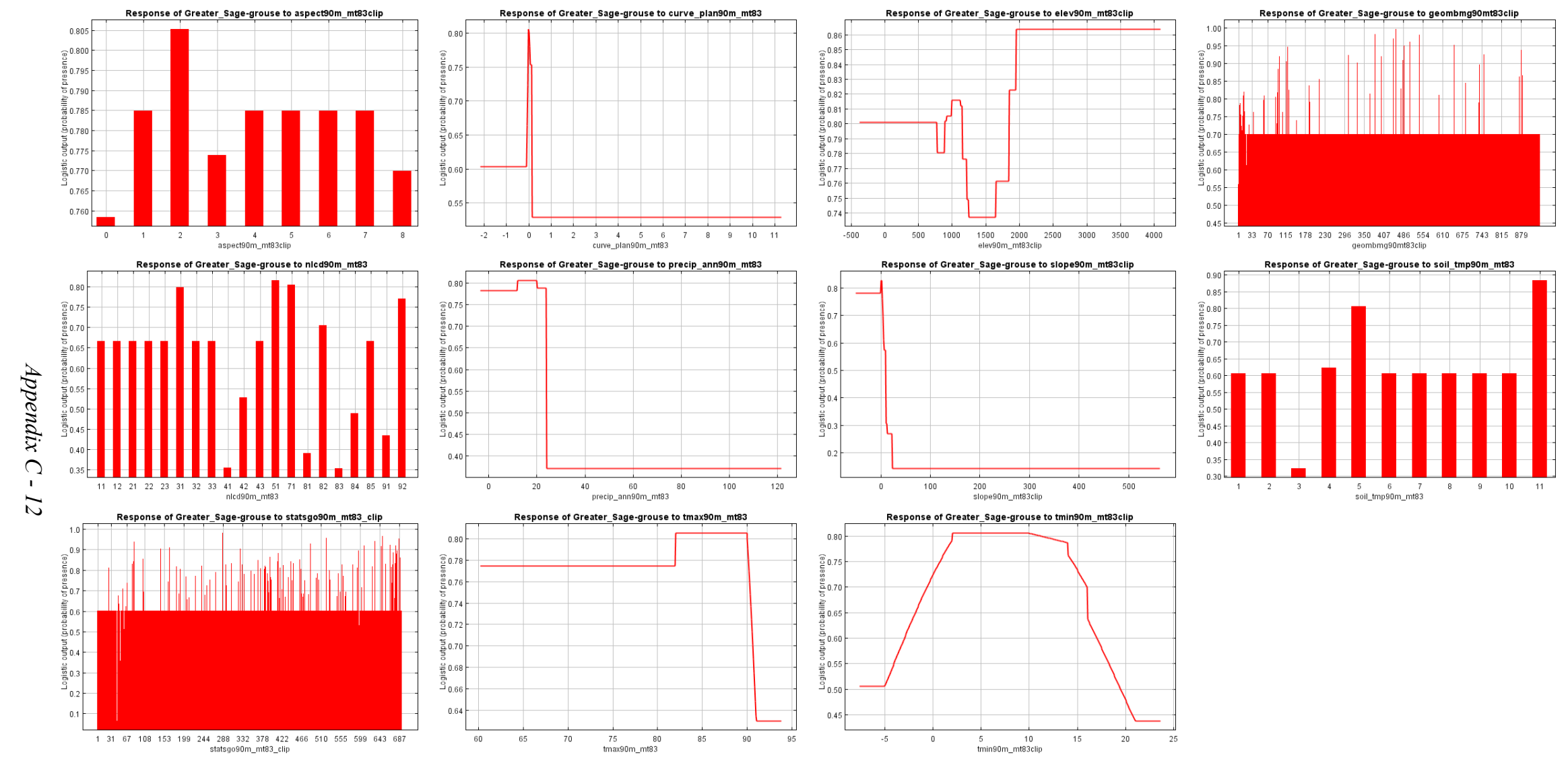

Figure C5. Response curves for individual environmental variables showing how the logistic prediction changes as each environmental variable is varied while all other environmental variables are held constant at their average sample values. The value on the $y$-axis is predicted probability of suitable conditions as given by the logistic formula $P(x)$ $=\exp (c 1 * f 1(x)+c 2 * f 2(x)+c 3 * f 3(x) \ldots) / Z$. Note that if any of the environmental variables are correlated, the marginal response curves can be misleading (e.g., two highly correlated variables with opposite response curves could effectively cancel each other out). Value definitions and/or links to metadata containing these definitions can be found in the Descriptions of Environmental Input Layers section of the appendix above. 


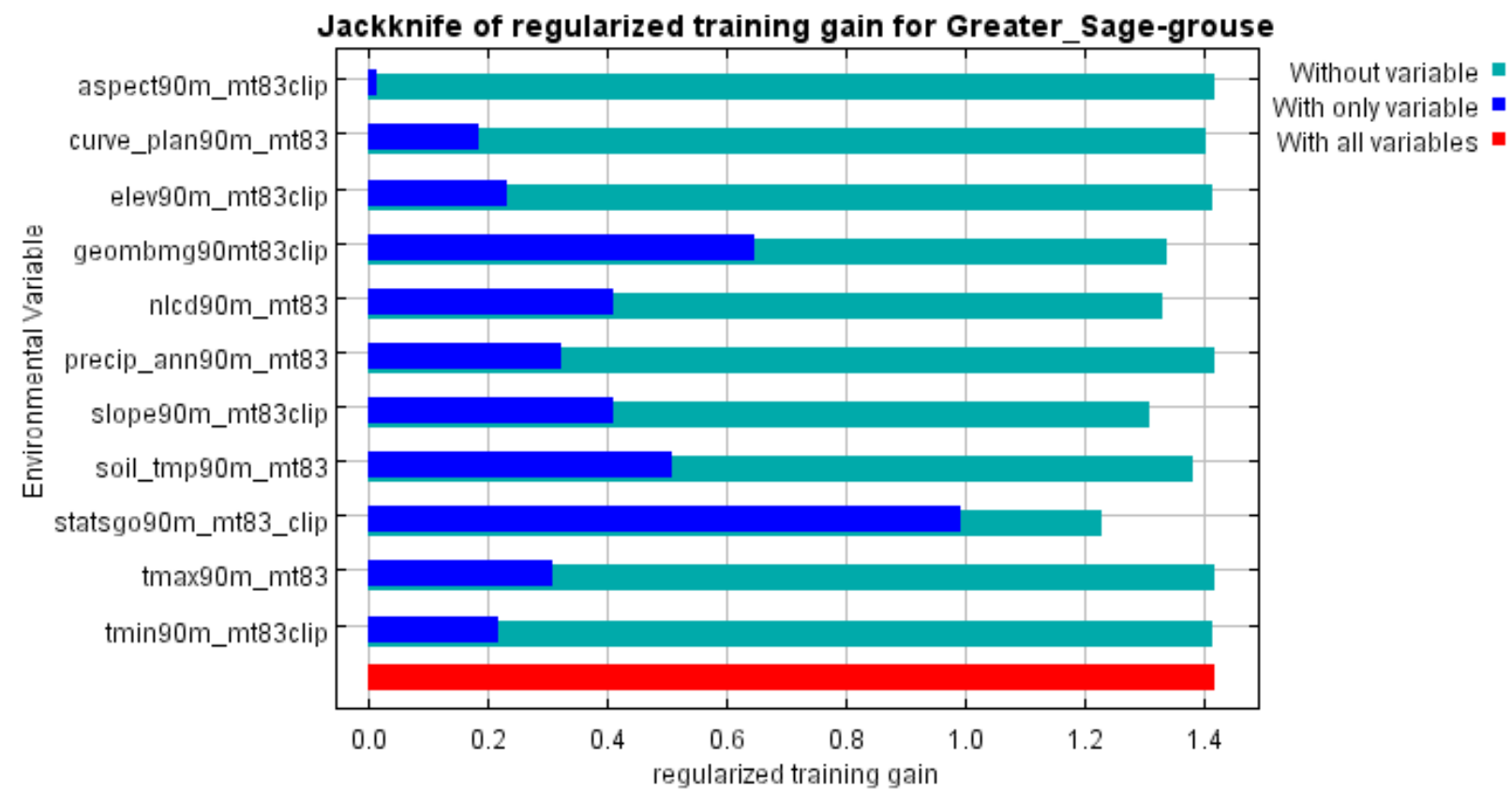

Figure C6. Jackknife chart showing the relative importance of environmental variables as a function of the change in "gain" (the log of the number of grid cells minus the average of the negative log probabilities of the sample locations) resulting from the exclusion or sole inclusion of the environmental variable in the model. Variables with the highest training gain resulting from sole inclusion of those variables (dark blue bars) are the best individual variables at describing suitable habitat for the species. Variables with the greatest reduction in training gain resulting from their exclusion (light blue bars) contain information on the species habitat use that is not present in other variables. The red bar indicates the maximum gain achieved with inclusion of all variables. 


\section{Mountain Plover (Charadrius montanus)}

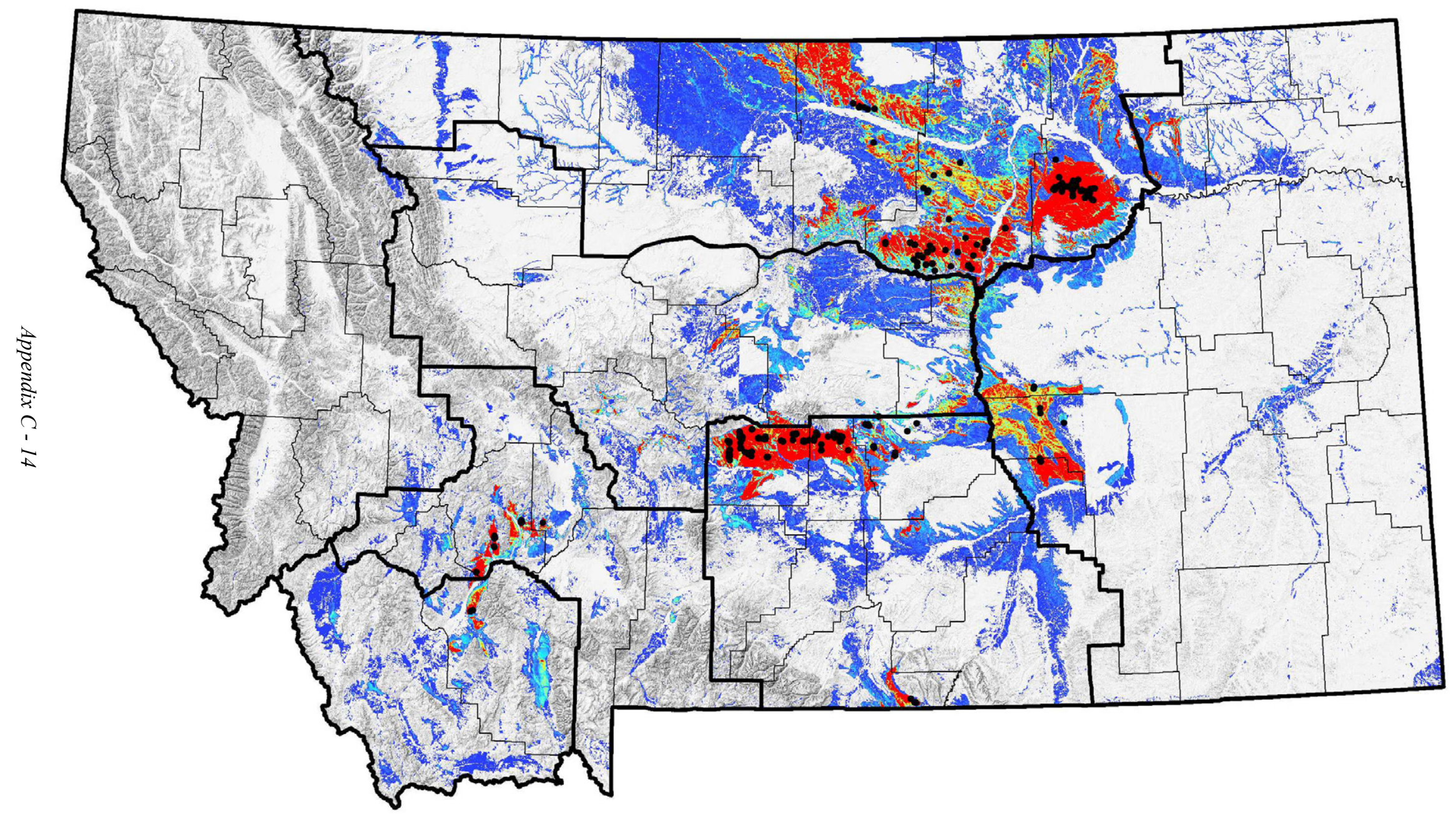

Figure C7. The hot-to-cold color map indicates the suitability of each grid cell as a function of the environmental variables at that grid cell. Hotter colors indicate areas that are predicted to have more suitable habitat for the species. Black dots are positive data used to build the model. A shaded relief map, BLM Field Office boundaries, and county lines are included for reference. 


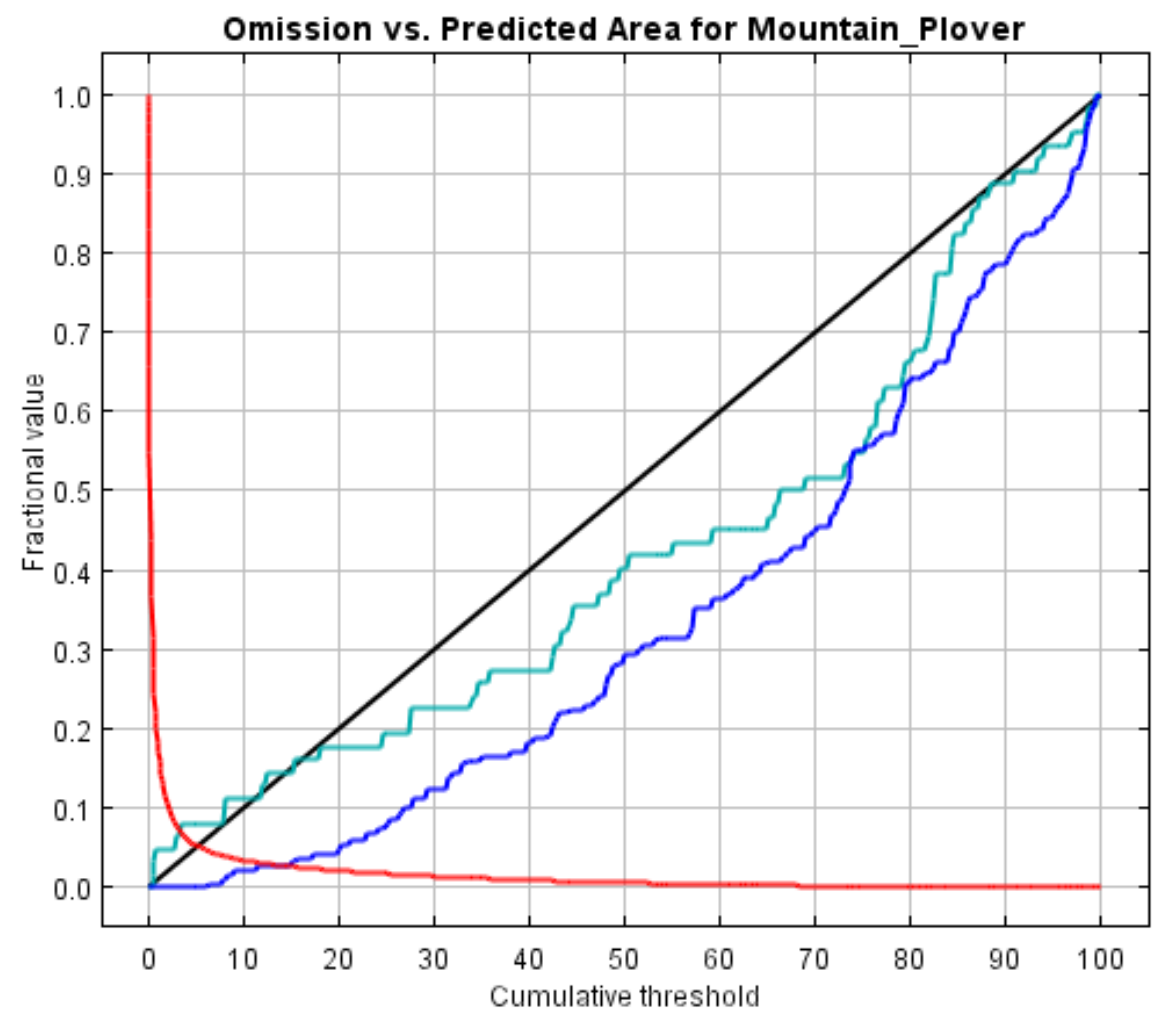

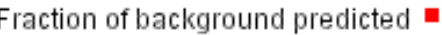
Omission on training samples Omission on test samples Predicted omission

Figure C8. An evaluation of omission error rates for training (dark blue line) and test (light blue line) data as a function of the cumulative threshold and overall predicted area. The red line indicates the overall fraction of the map area fitting each value of the cumulative threshold. The black line is the predicted omission rate for each cumulative threshold. 


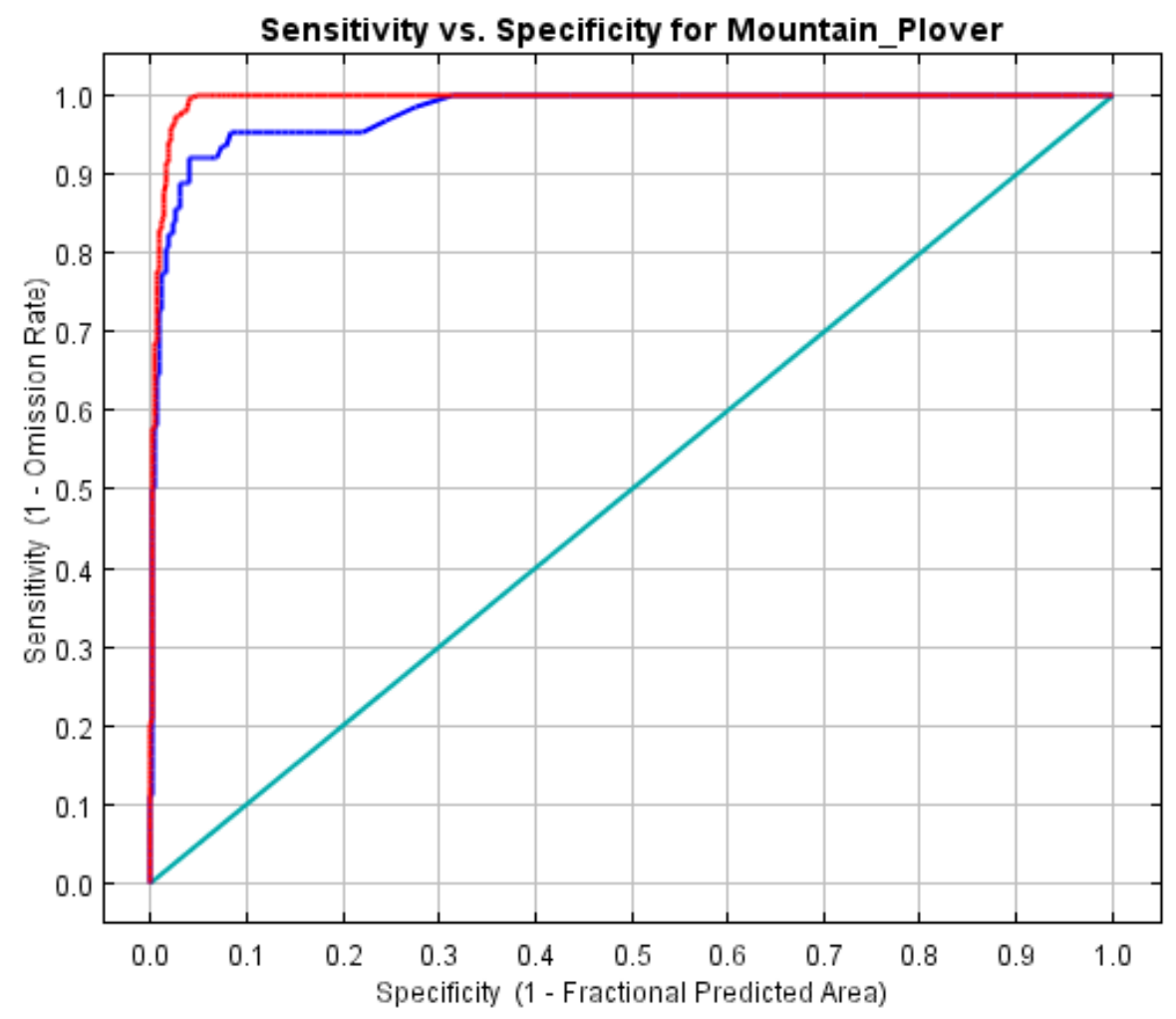

Training data $(\mathrm{AUC}=0.994)$.

Test data $(A \cup C=0.979)$.

Random Prediction (AUC $=0.5)$

Figure C9. Receiver Operating Characteristic (ROC) curve evaluating the overall predictive power of the model with the Area Under the Curve (AUC). The AUC value indicates that when two random locations are chosen the model has that probability of assigning a higher cumulative threshold value to the location with more suitable habitat. The light blue line indicates how a neutral or random model would perform (i.e., it only has a 50\% probability of assigning a higher cumulative threshold value to a random location with more suitable habitat than a random location with less suitable habitat). The further toward the top left of the graph the training (red) and test (blue) data lines are, the better the model is at predicting the presences contained in the training data. Sensitivity (plotted on the y-axis) is the proportion of positive locations that were correctly classified by the model. Sensitivity is also known as the true positive rate and can be thought of as the degree of absence of omission errors. Specificity is the proportion of random locations chosen from the background (these pseudo-absences are used instead of true negative locations) that were correctly classified by the model as negative. One minus the Specificity (plotted on the $x$-axis) is known as the false positive rate and represents the commission error rate. 

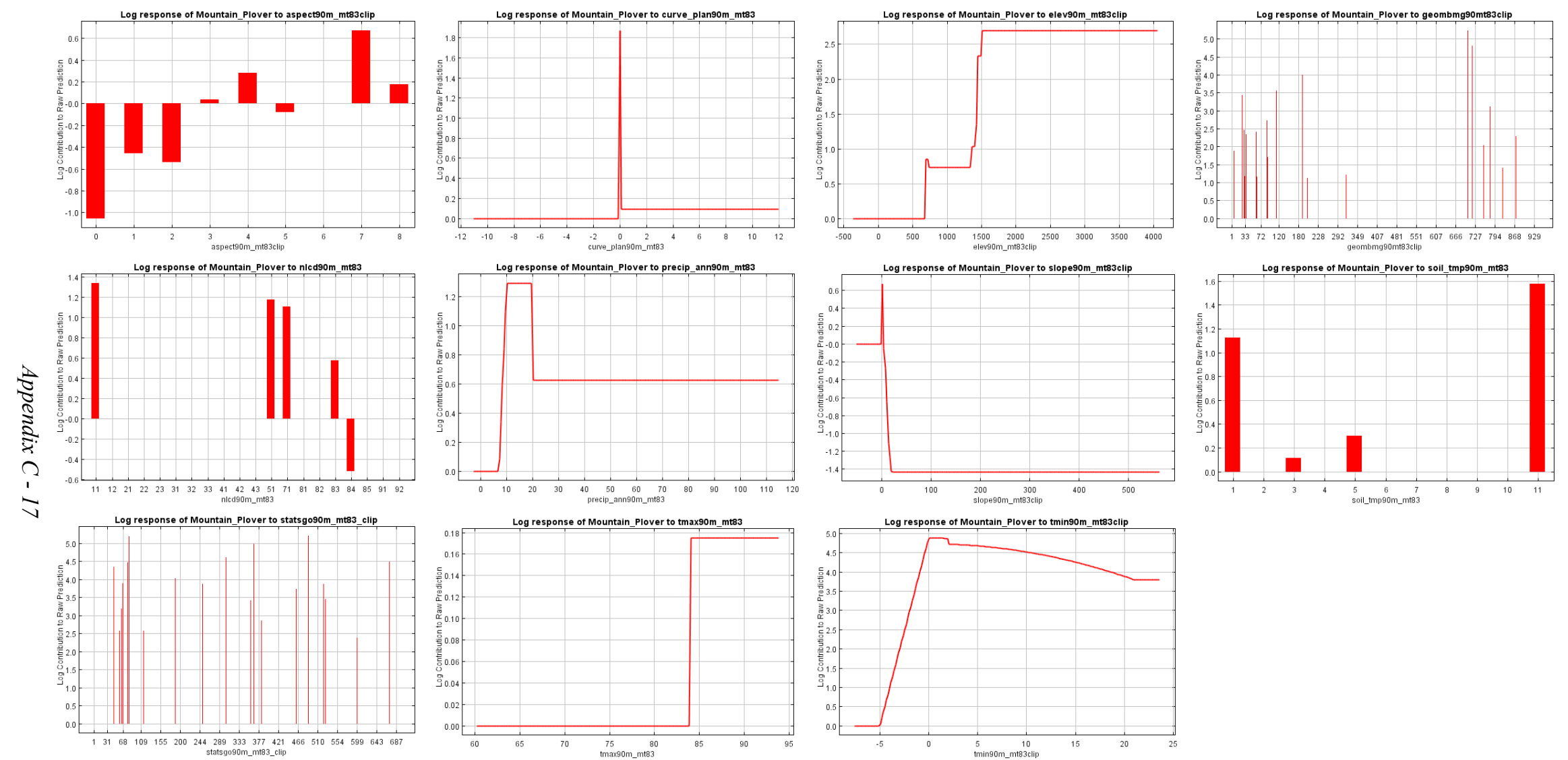

Figure C10. Response curves for individual environmental variables showing how the logistic prediction changes as each environmental variable is varied while all other environmental variables are held constant at their average sample values. The value on the $y$-axis is predicted probability of suitable conditions as given by the logistic formula $P(x)$ $=\exp (c 1 * f 1(x)+c 2 * f 2(x)+c 3 * f 3(x) \ldots) / Z$. Note that if any of the environmental variables are correlated, the marginal response curves can be misleading (e.g., two highly correlated variables with opposite response curves could effectively cancel each other out). Value definitions and/or links to metadata containing these definitions can be found in the Descriptions of Environmental Input Layers section of the appendix above. 


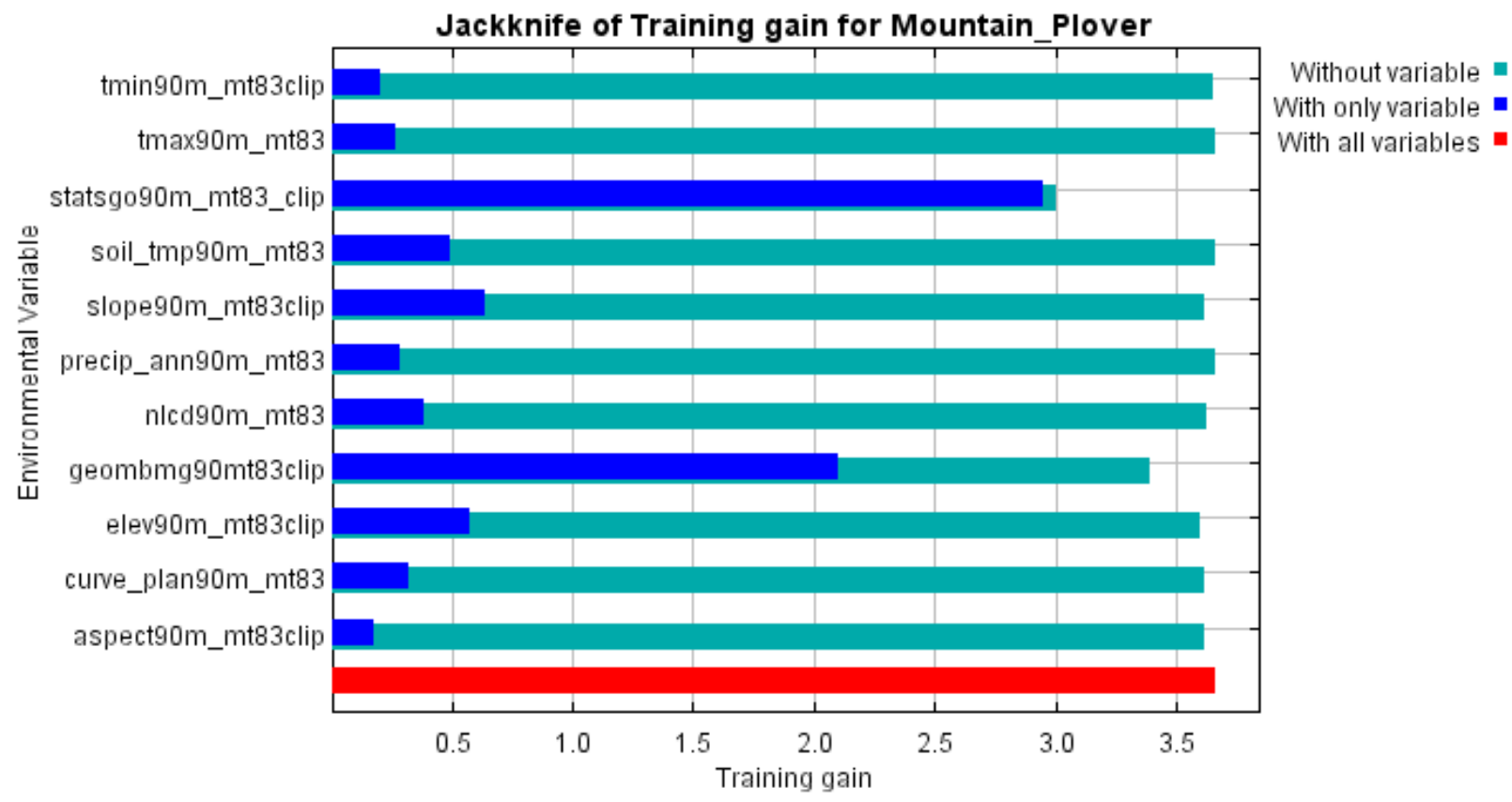

Figure C11. Jackknife chart showing the relative importance of environmental variables as a function of the change in "gain" (the log of the number of grid cells minus the average of the negative log probabilities of the sample locations) resulting from the exclusion or sole inclusion of the environmental variable in the model. Variables with the highest training gain resulting from sole inclusion of those variables (dark blue bars) are the best individual variables at describing suitable habitat for the species. Variables with the greatest reduction in training gain resulting from their exclusion (light blue bars) contain information on the species habitat use that is not present in other variables. The red bar indicates the maximum gain achieved with inclusion of all variables. 


\section{Long-billed Curlew (Numenius americanus)}

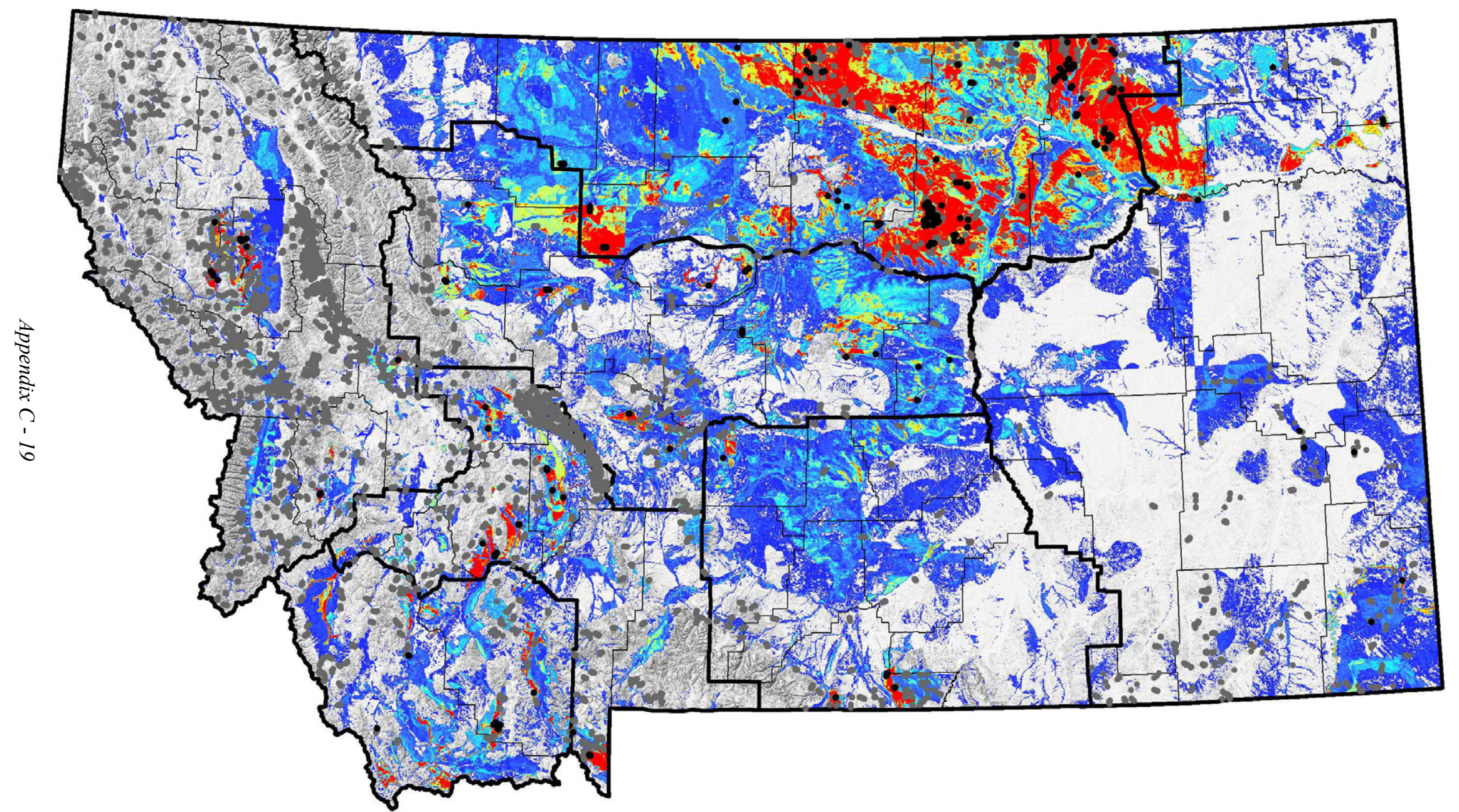

Figure C12. The hot-to-cold color map indicates the suitability of each grid cell as a function of the environmental variables at that grid cell. Hotter colors indicate areas that are predicted to have more suitable habitat for the species. Black dots are positive data used to build the model. Gray dots are locations where a survey capable of detecting the species has been performed. A shaded relief map, BLM Field Office boundaries, and county lines are included for reference. 


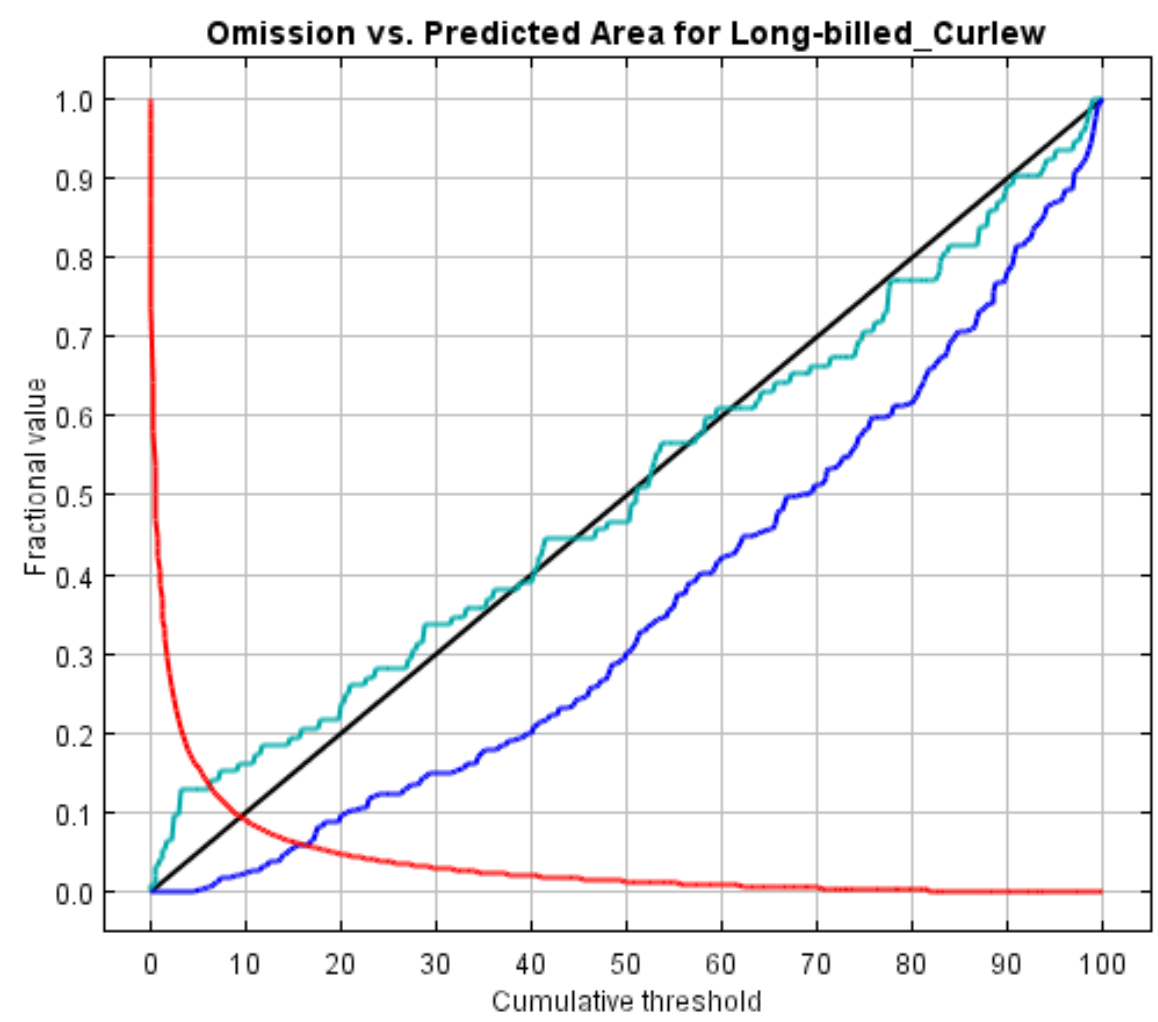

Fraction of background predicted

Omission on training samples Omission on test samples Predicted omission $\mathbf{0}$

Figure C13. An evaluation of omission error rates for training (dark blue line) and test (light blue line) data as a function of the cumulative threshold and overall predicted area. The red line indicates the overall fraction of the map area fitting each value of the cumulative threshold. The black line is the predicted omission rate for each cumulative threshold. 


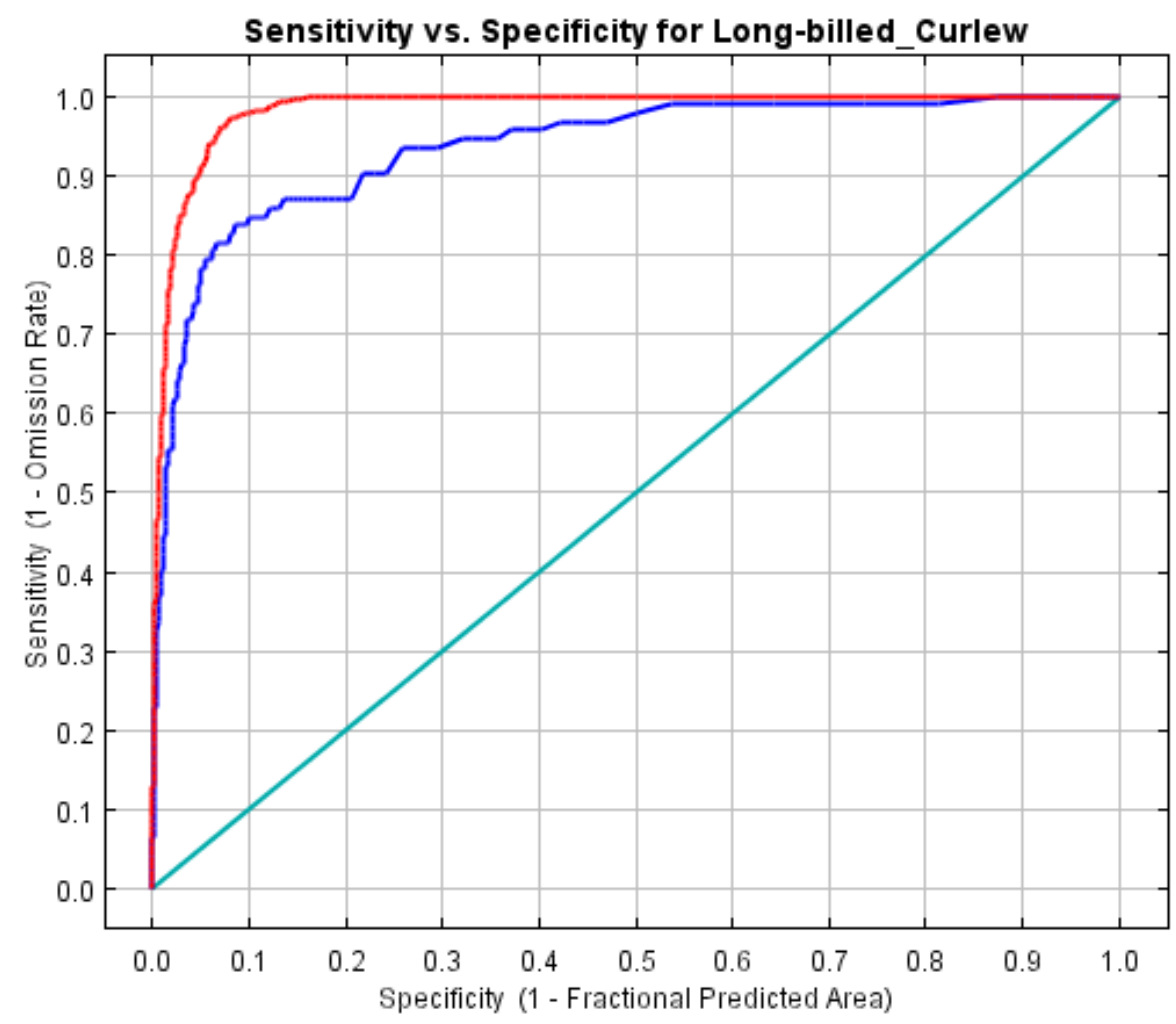

Training data $(\mathrm{AUC}=0.984)$.

Test data $(\mathrm{AUC}=0.934)$.

Random Prediction (AUC $=0.5)$

Figure C14. Receiver Operating Characteristic (ROC) curve evaluating the overall predictive power of the model with the Area Under the Curve (AUC). The AUC value indicates that when two random locations are chosen the model has that probability of assigning a higher cumulative threshold value to the location with more suitable habitat. The light blue line indicates how a neutral or random model would perform (i.e., it only has a 50\% probability of assigning a higher cumulative threshold value to a random location with more suitable habitat than a random location with less suitable habitat). The further toward the top left of the graph the training (red) and test (blue) data lines are, the better the model is at predicting the presences contained in the training data. Sensitivity (plotted on the y-axis) is the proportion of positive locations that were correctly classified by the model. Sensitivity is also known as the true positive rate and can be thought of as the degree of absence of omission errors. Specificity is the proportion of random locations chosen from the background (these pseudo-absences are used instead of true negative locations) that were correctly classified by the model as negative. One minus the Specificity (plotted on the $x$-axis) is known as the false positive rate and represents the commission error rate. 

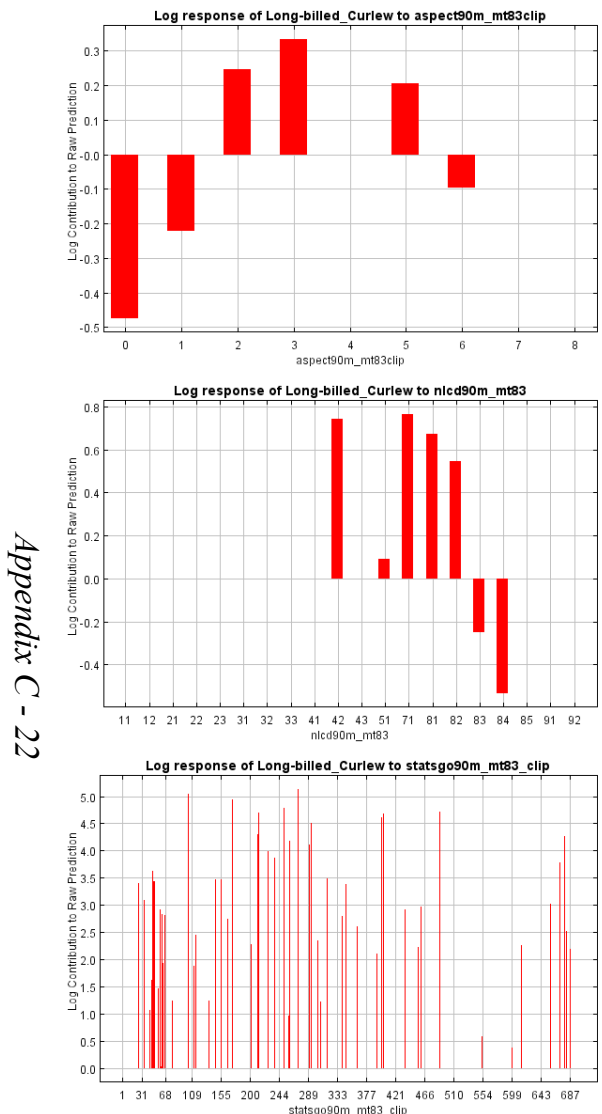
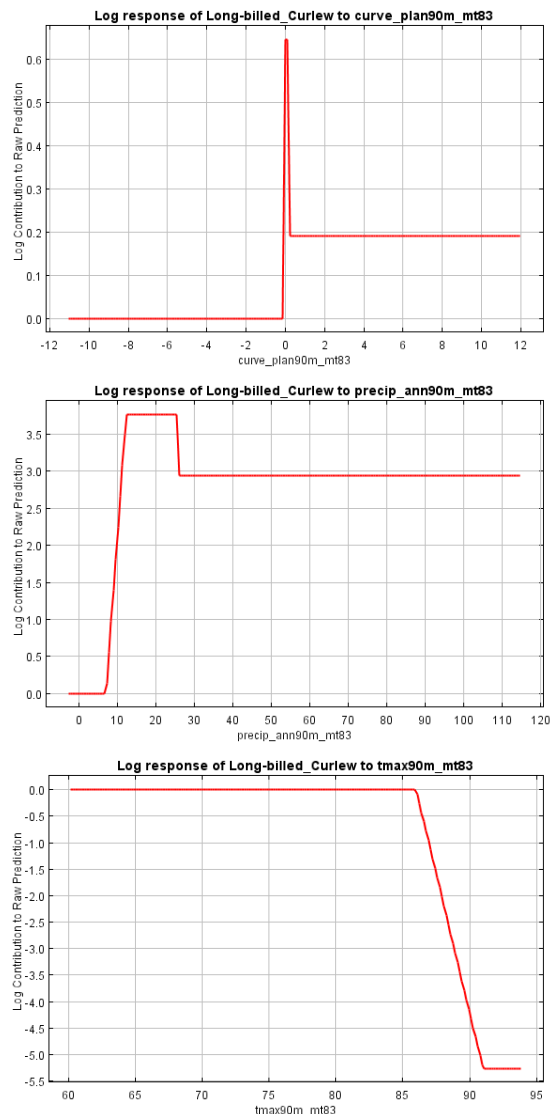
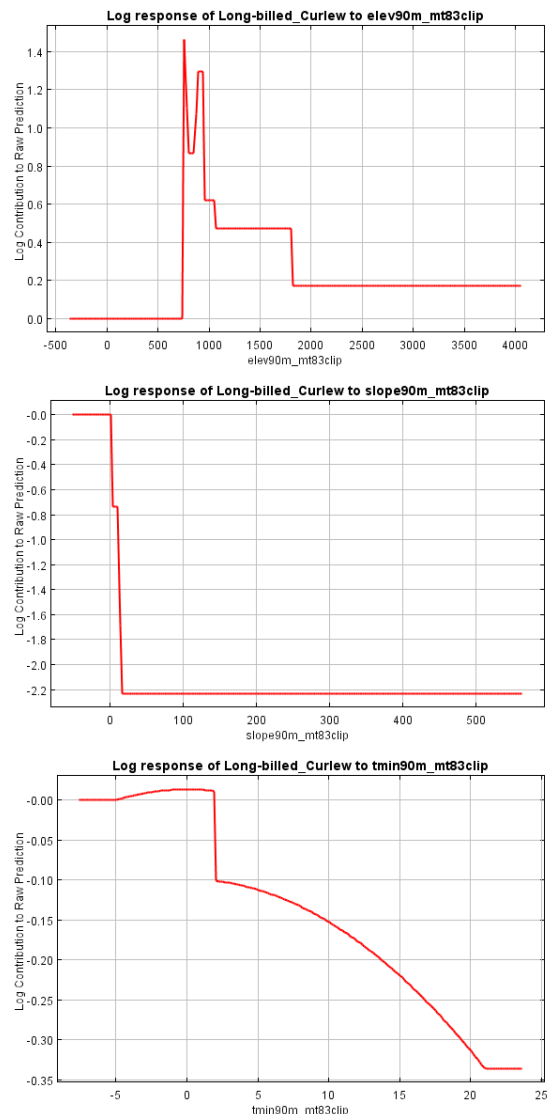
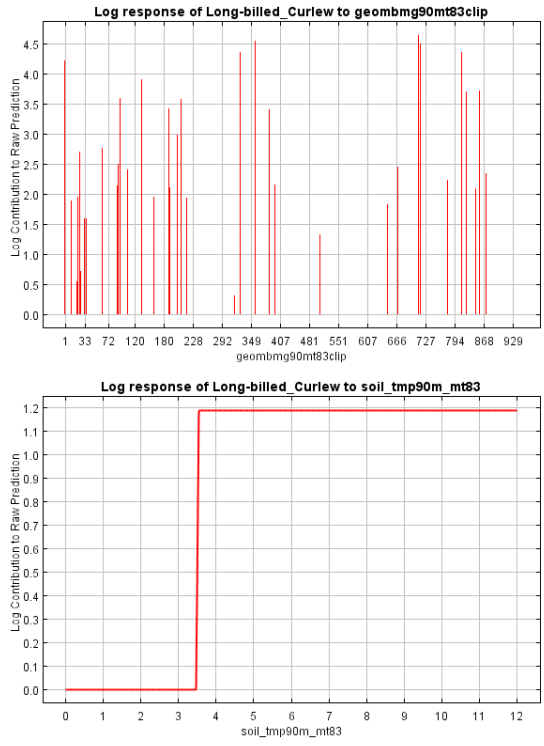

Figure C15. Response curves for individual environmental variables showing how the logistic prediction changes as each environmental variable is varied while all other environmental variables are held constant at their average sample values. The value on the $y$-axis is predicted probability of suitable conditions as given by the logistic formula $P(x)$ $=\exp (c 1 * f 1(x)+c 2 * f 2(x)+c 3 * f 3(x) \ldots) / Z$. Note that if any of the environmental variables are correlated, the marginal response curves can be misleading (e.g., two highly correlated variables with opposite response curves could effectively cancel each other out). Value definitions and/or links to metadata containing these definitions can be found in the Descriptions of Environmental Input Layers section of the appendix above. 


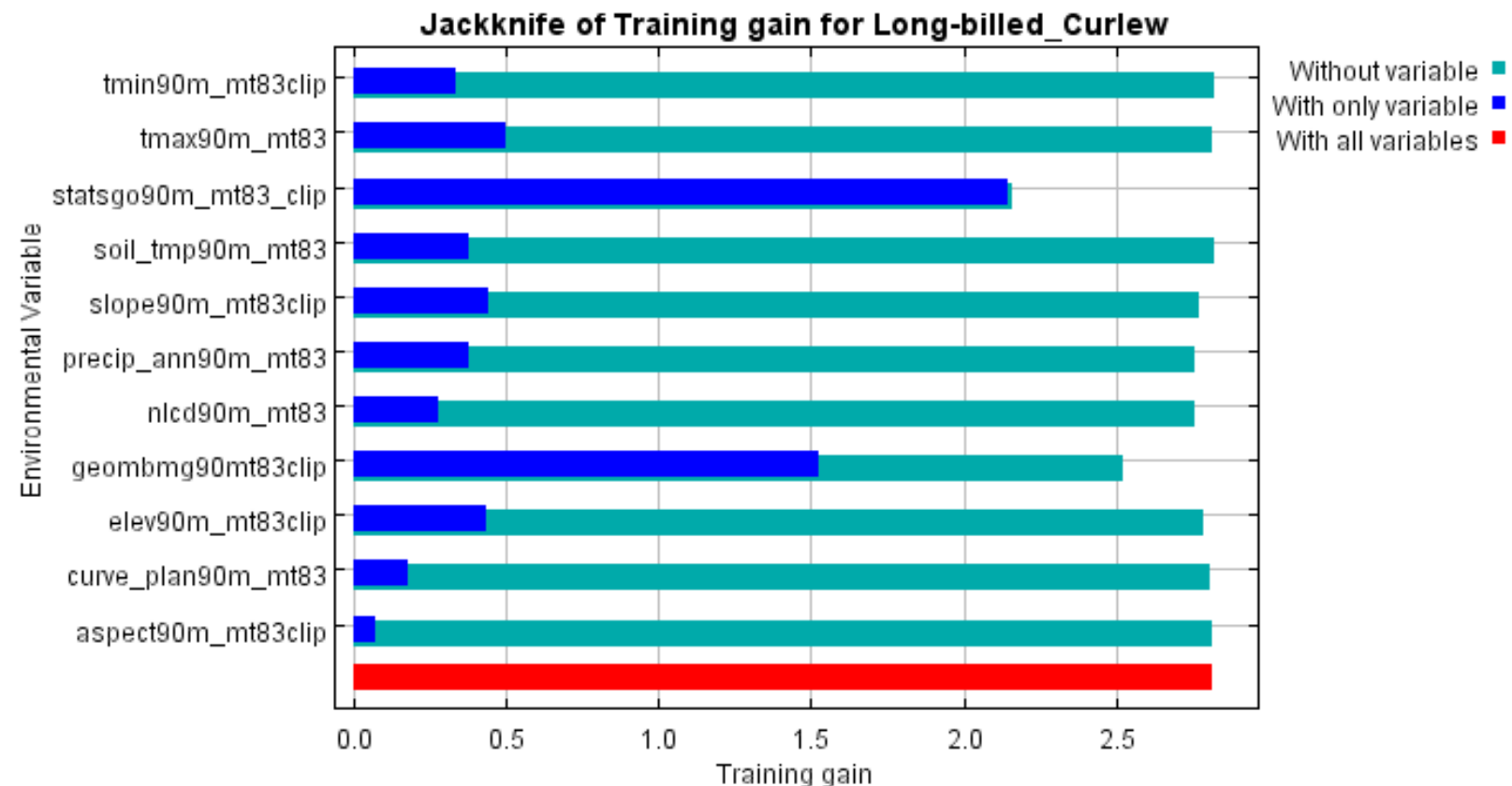

Figure C16. Jackknife chart showing the relative importance of environmental variables as a function of the change in "gain" (the log of the number of grid cells minus the average of the negative log probabilities of the sample locations) resulting from the exclusion or sole inclusion of the environmental variable in the model. Variables with the highest training gain resulting from sole inclusion of those variables (dark blue bars) are the best individual variables at describing suitable habitat for the species. Variables with the greatest reduction in training gain resulting from their exclusion (light blue bars) contain information on the species habitat use that is not present in other variables. The red bar indicates the maximum gain achieved with inclusion of all variables. 


\section{Sprague's Pipit (Anthus spragueii)}

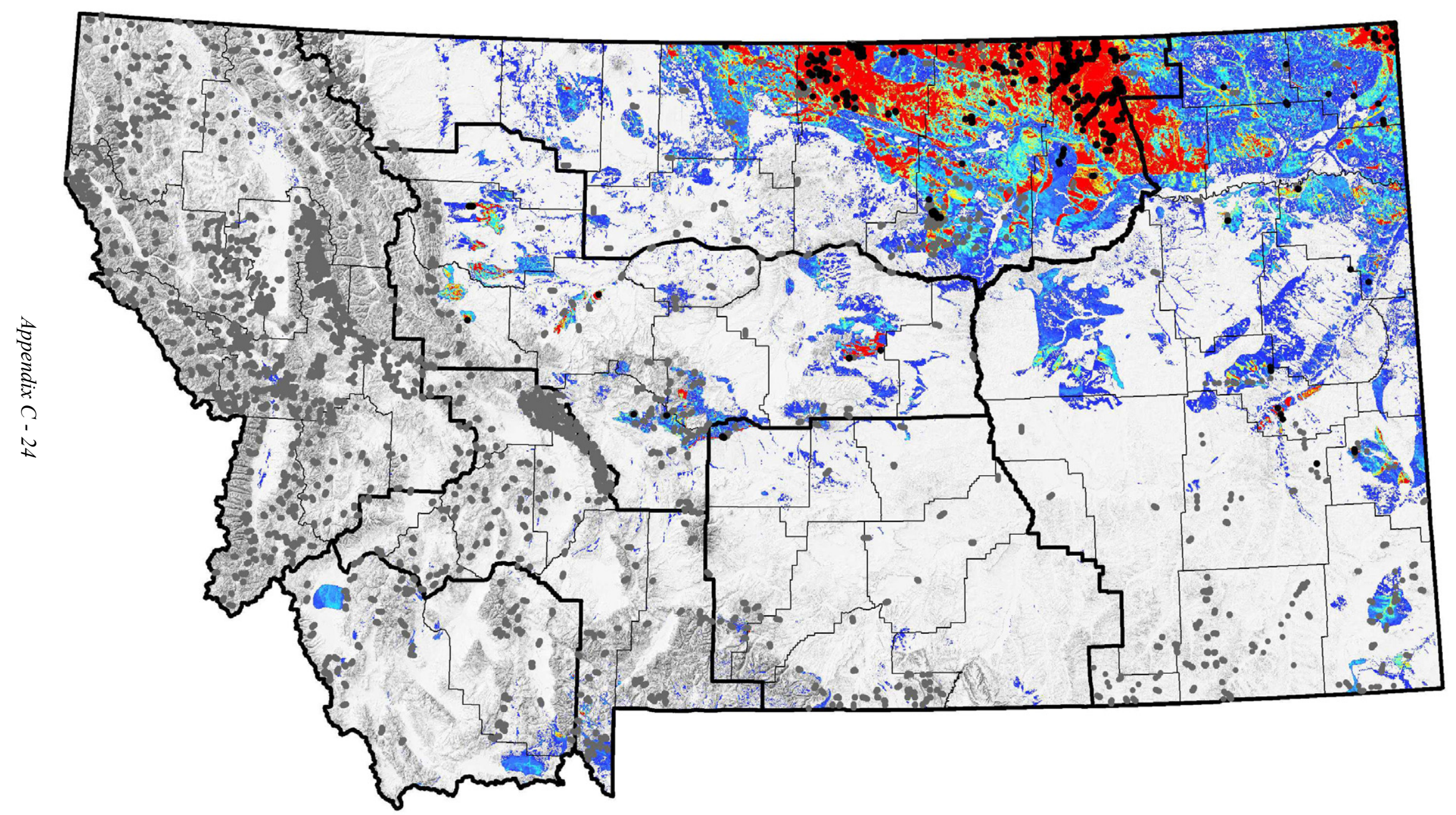

Figure C17. The hot-to-cold color map indicates the suitability of each grid cell as a function of the environmental variables at that grid cell. Hotter colors indicate areas that are predicted to have more suitable habitat for the species. Black dots are positive data used to build the model. Gray dots are locations where a survey capable of detecting the species has been performed. A shaded relief map, BLM Field Office boundaries, and county lines are included for reference. 


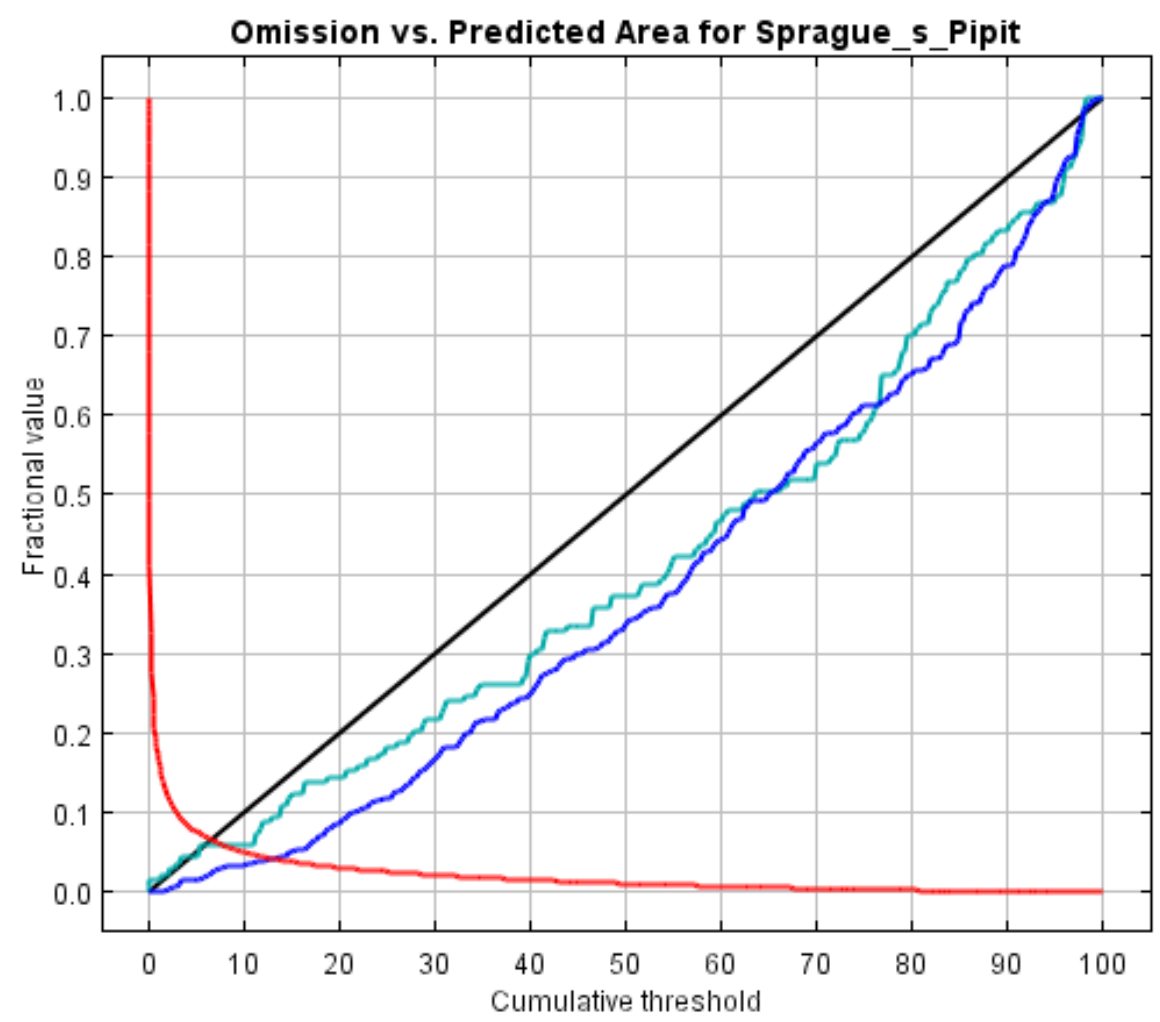

Fraction of background predicted $\mathbf{m}$ Omission on training samples Omission on test samples Predicted omission -

Figure C18. An evaluation of omission error rates for training (dark blue line) and test (light blue line) data as a function of the cumulative threshold and overall predicted area. The red line indicates the overall fraction of the map area fitting each value of the cumulative threshold. The black line is the predicted omission rate for each cumulative threshold. 


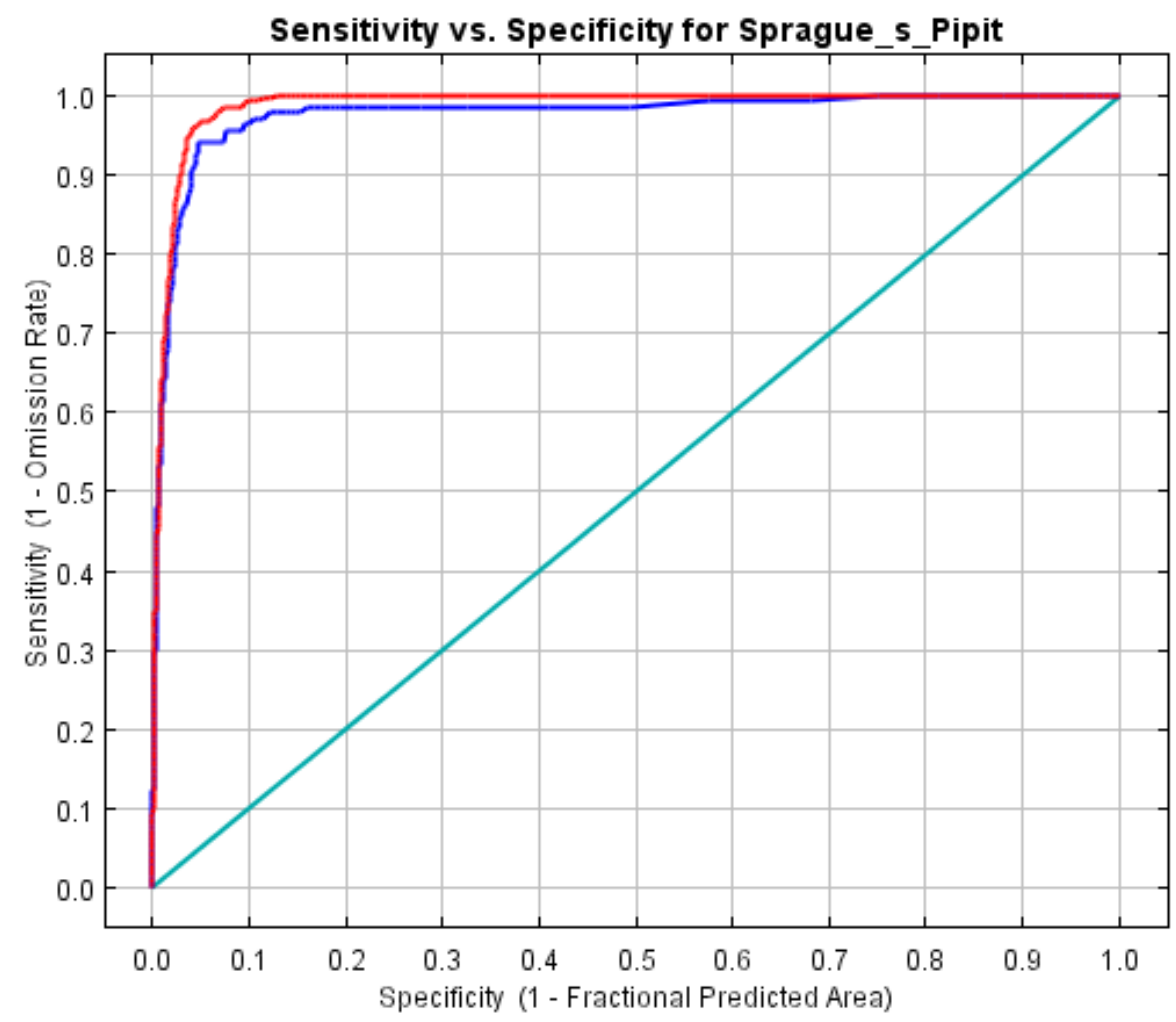

Training data $(\mathrm{AUC}=0.988)$

Test data $(\mathrm{AUC}=0.976)$

Random Prediction (AUC $=0.5)$

Figure C19. Receiver Operating Characteristic (ROC) curve evaluating the overall predictive power of the model with the Area Under the Curve (AUC). The AUC value indicates that when two random locations are chosen the model has that probability of assigning a higher cumulative threshold value to the location with more suitable habitat. The light blue line indicates how a neutral or random model would perform (i.e., it only has a 50\% probability of assigning a higher cumulative threshold value to a random location with more suitable habitat than a random location with less suitable habitat). The further toward the top left of the graph the training (red) and test (blue) data lines are, the better the model is at predicting the presences contained in the training data. Sensitivity (plotted on the y-axis) is the proportion of positive locations that were correctly classified by the model. Sensitivity is also known as the true positive rate and can be thought of as the degree of absence of omission errors. Specificity is the proportion of random locations chosen from the background (these pseudo-absences are used instead of true negative locations) that were correctly classified by the model as negative. One minus the Specificity (plotted on the $x$-axis) is known as the false positive rate and represents the commission error rate. 

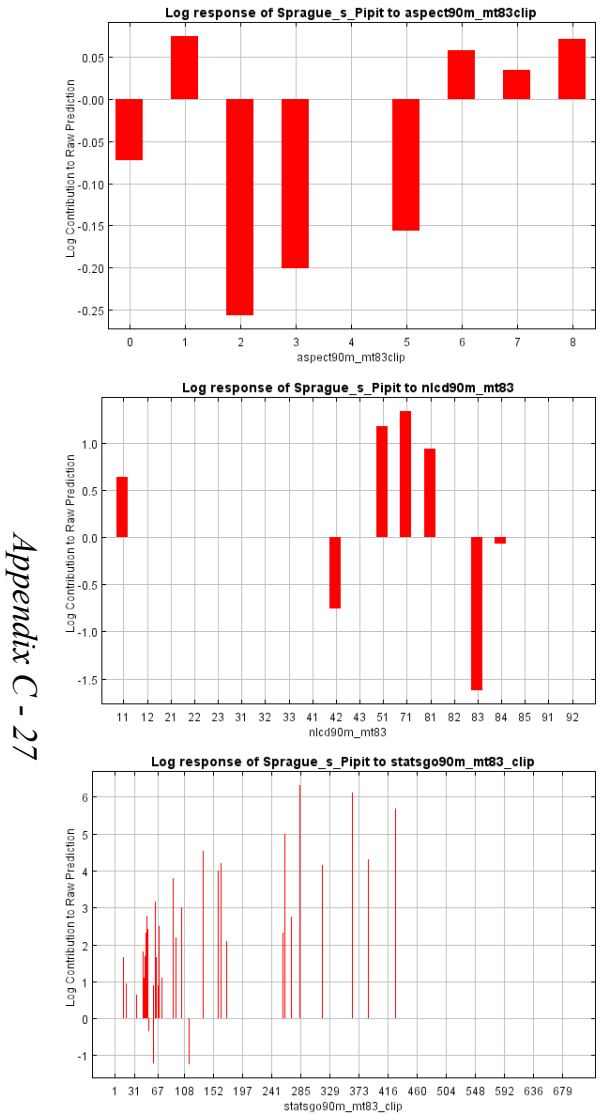
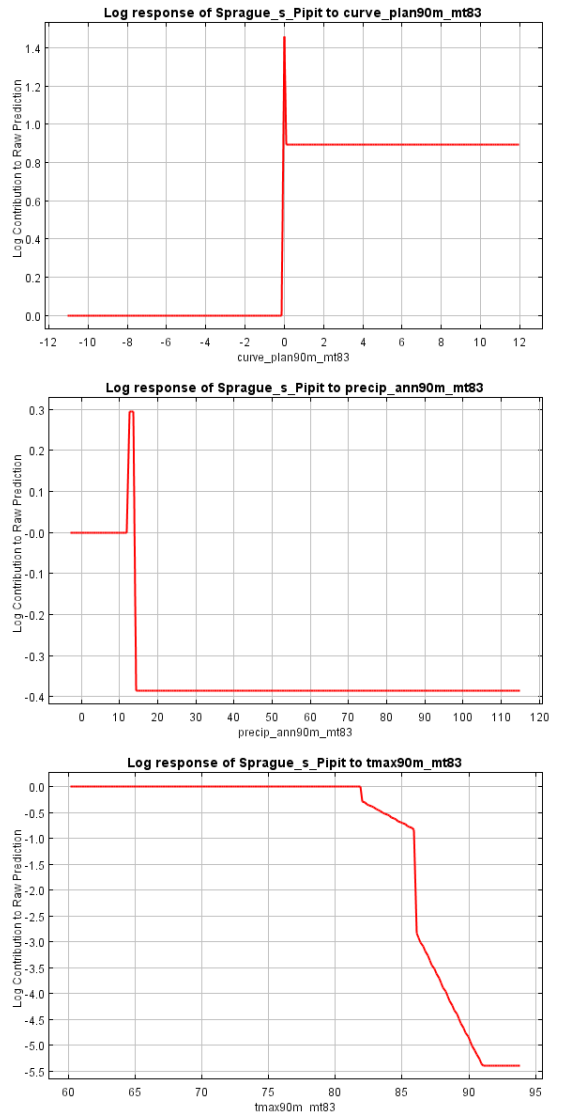
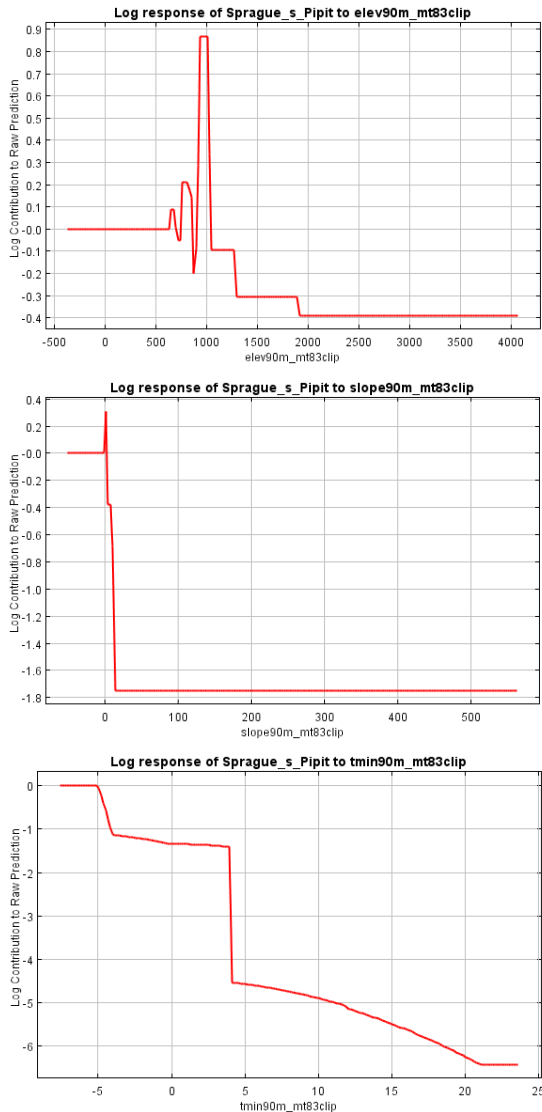

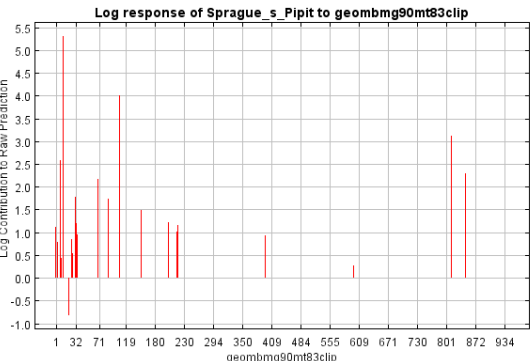

Log response of Sprague $s$ pipit to soil tmp9om mms

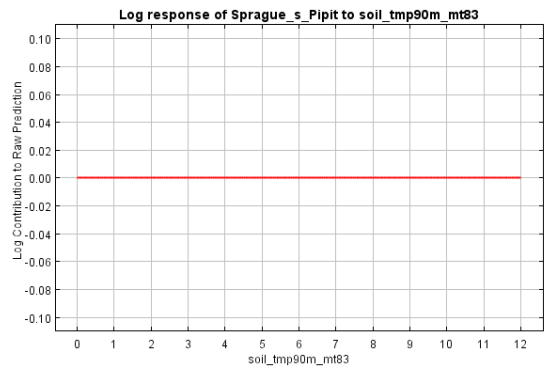

Figure C20. Response curves for individual environmental variables showing how the logistic prediction changes as each environmental variable is varied while all other environmental variables are held constant at their average sample values. The value on the $y$-axis is predicted probability of suitable conditions as given by the logistic formula $P(x)$ $=\exp (c 1 * f 1(x)+c 2 * f 2(x)+c 3 * f 3(x) \ldots) / Z$. Note that if any of the environmental variables are correlated, the marginal response curves can be misleading (e.g., two highly correlated variables with opposite response curves could effectively cancel each other out). Value definitions and/or links to metadata containing these definitions can be found in the Descriptions of Environmental Input Layers section of the appendix above. 


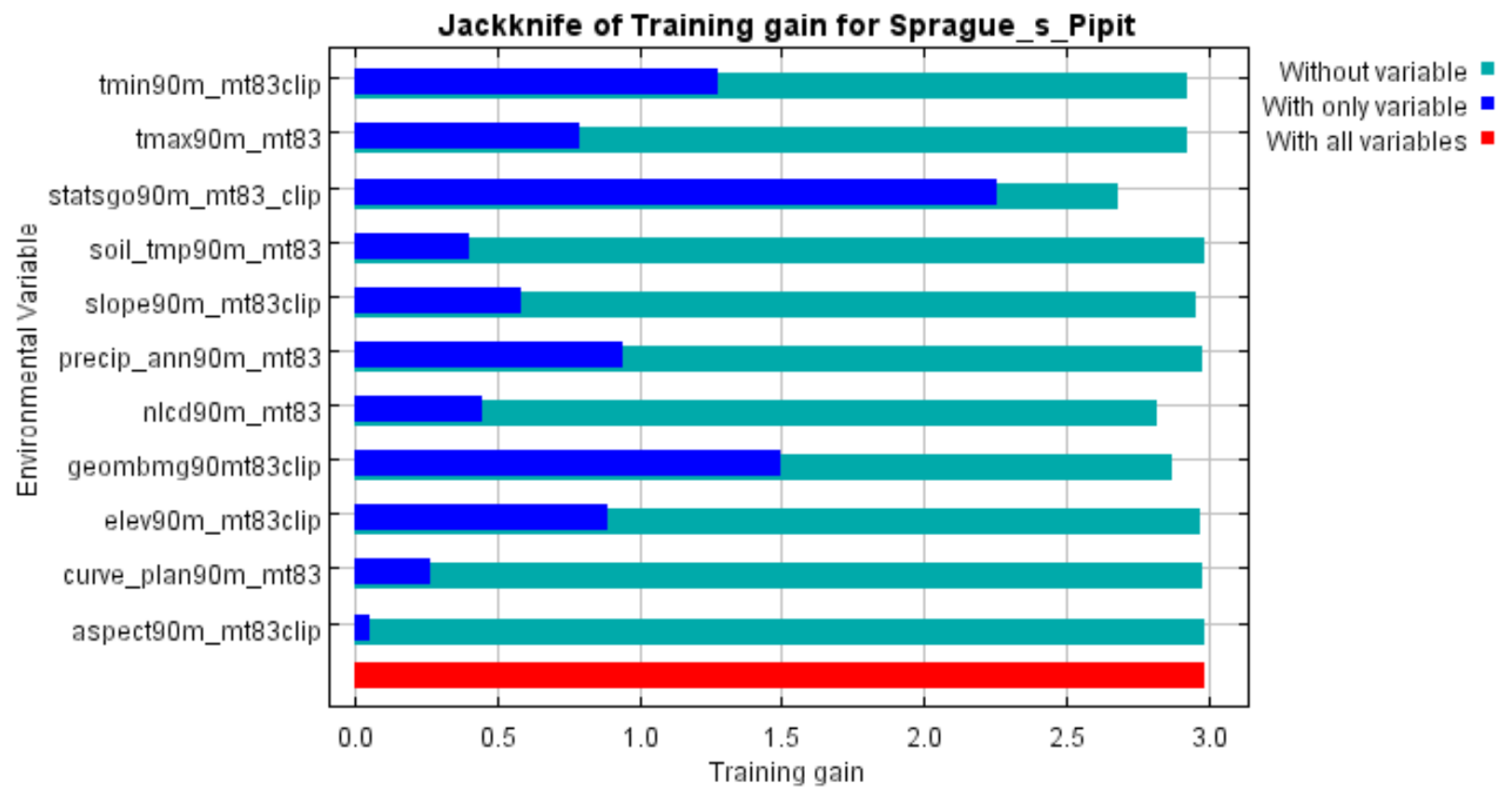

Figure C21. Jackknife chart showing the relative importance of environmental variables as a function of the change in "gain" (the log of the number of grid cells minus the average of the negative log probabilities of the sample locations) resulting from the exclusion or sole inclusion of the environmental variable in the model. Variables with the highest training gain resulting from sole inclusion of those variables (dark blue bars) are the best individual variables at describing suitable habitat for the species. Variables with the greatest reduction in training gain resulting from their exclusion (light blue bars) contain information on the species habitat use that is not present in other variables. The red bar indicates the maximum gain achieved with inclusion of all variables. 


\section{Brewer's Sparrow (Spizella breweri)}

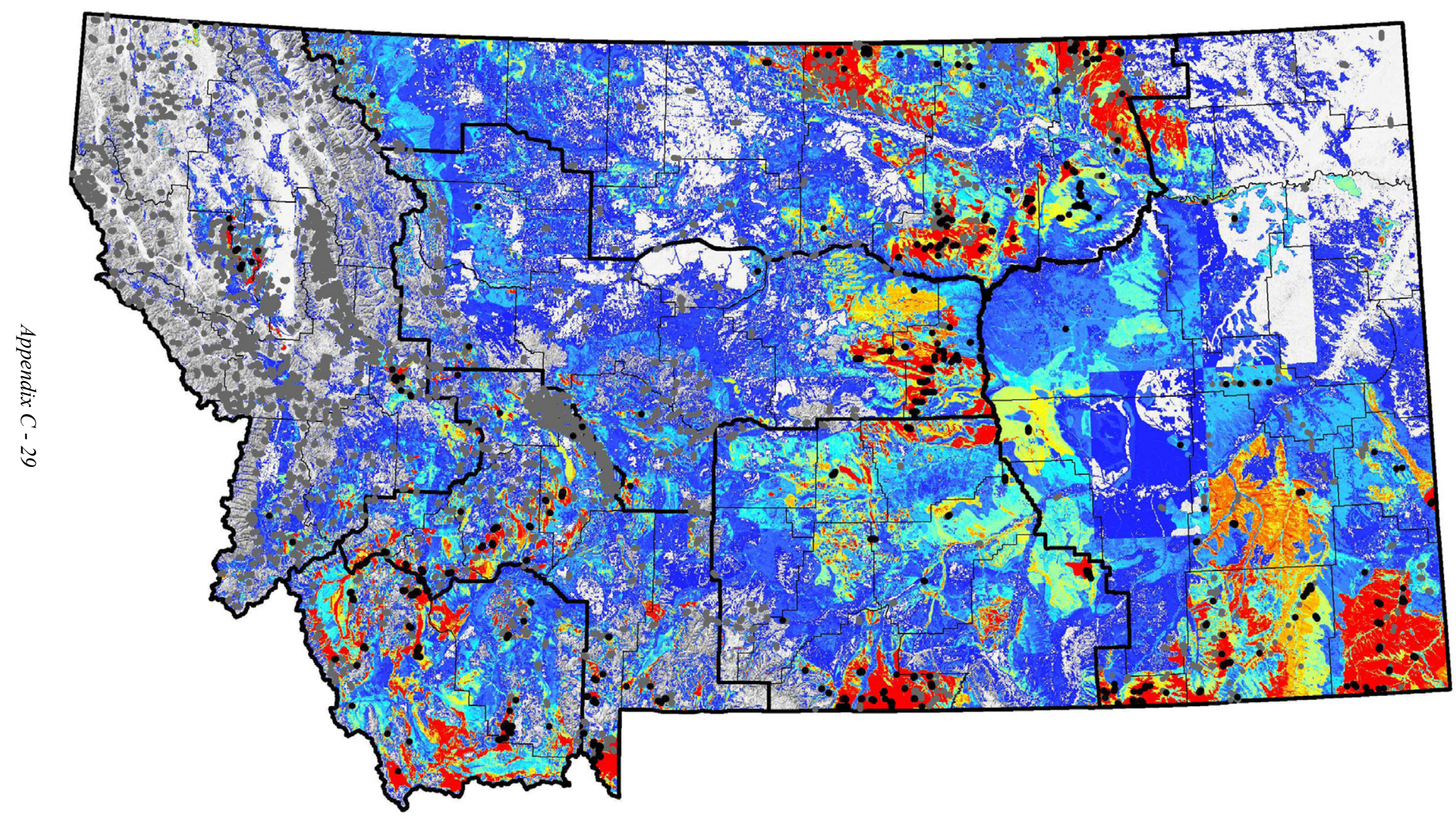

Figure C22. The hot-to-cold color map indicates the suitability of each grid cell as a function of the environmental variables at that grid cell. Hotter colors indicate areas that are predicted to have more suitable habitat for the species. Black dots are positive data used to build the model. Gray dots are locations where a survey capable of detecting the species has been performed. A shaded relief map, BLM Field Office boundaries, and county lines are included for reference. 


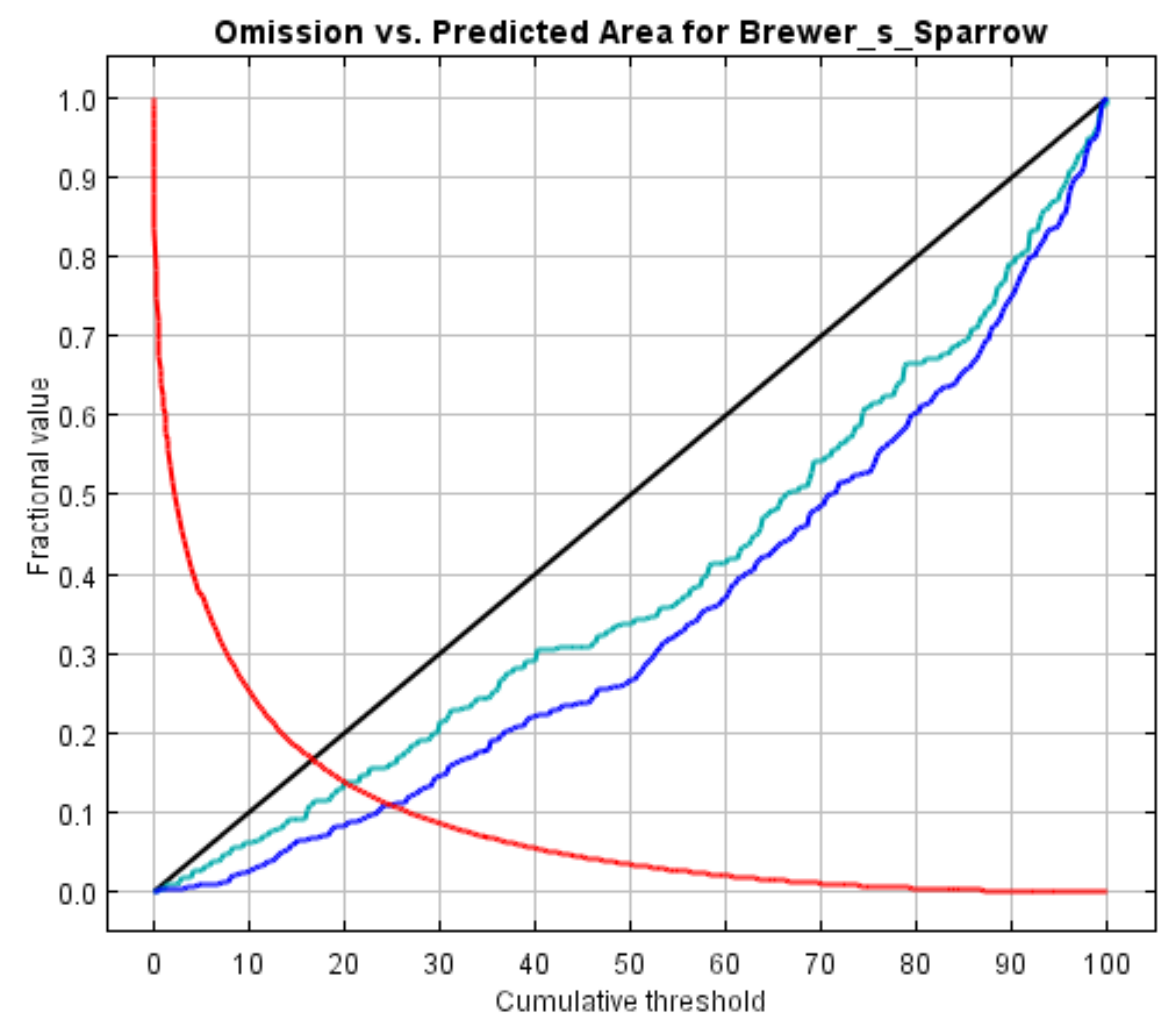

Fraction of background predicted $\mathrm{m}$ Omission on training samples Omission on test samples Predicted omission

Figure C23. An evaluation of omission error rates for training (dark blue line) and test (light blue line) data as a function of the cumulative threshold and overall predicted area. The red line indicates the overall fraction of the map area fitting each value of the cumulative threshold. The black line is the predicted omission rate for each cumulative threshold. 


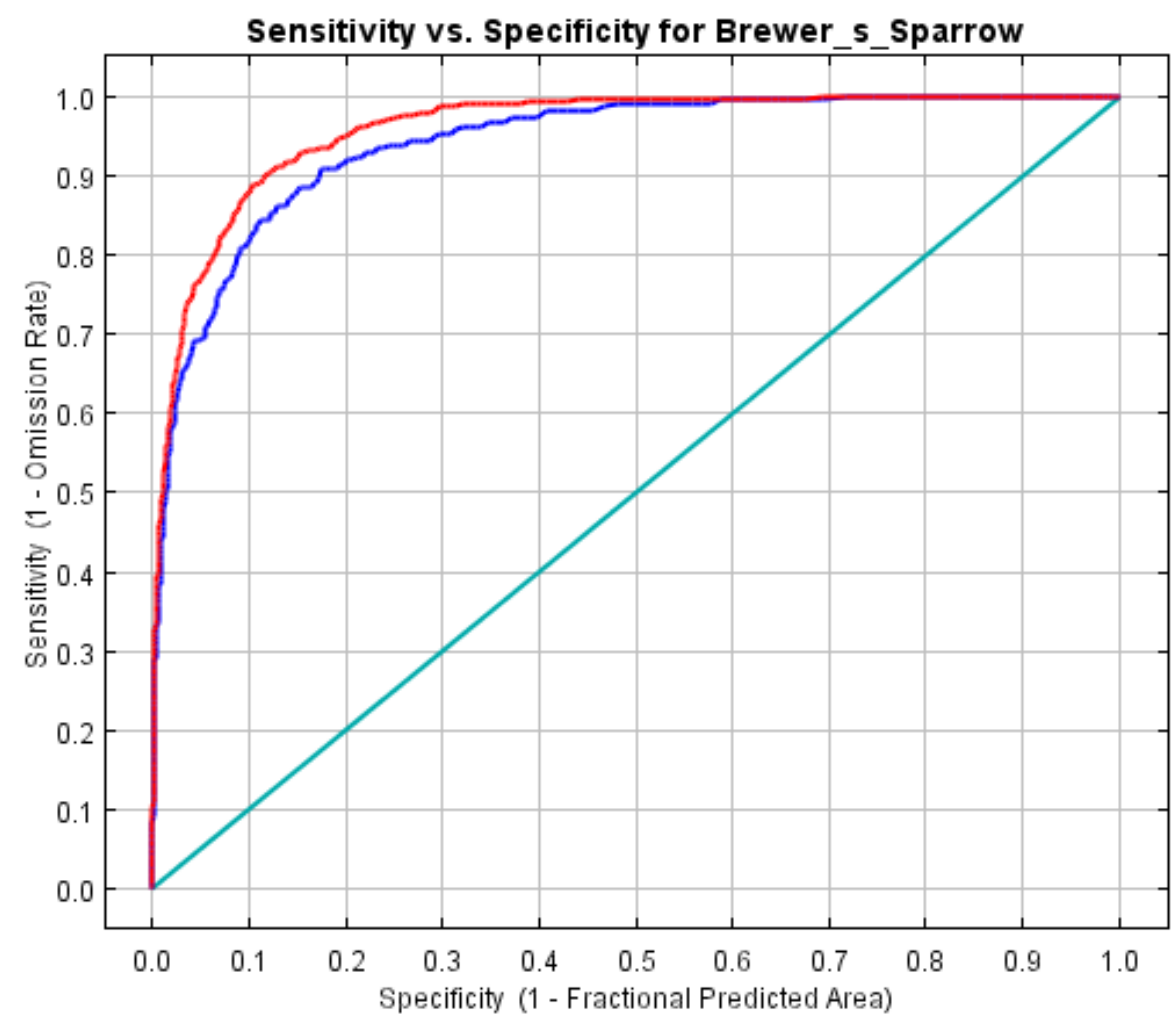

Training data $(\mathrm{AUC}=0.959)$.

Test data $(A \cup C=0.940)$.

Random Prediction (AUC $=0.5)$

Figure C24. Receiver Operating Characteristic (ROC) curve evaluating the overall predictive power of the model with the Area Under the Curve (AUC). The AUC value indicates that when two random locations are chosen the model has that probability of assigning a higher cumulative threshold value to the location with more suitable habitat. The light blue line indicates how a neutral or random model would perform (i.e., it only has a 50\% probability of assigning a higher cumulative threshold value to a random location with more suitable habitat than a random location with less suitable habitat). The further toward the top left of the graph the training (red) and test (blue) data lines are, the better the model is at predicting the presences contained in the training data. Sensitivity (plotted on the y-axis) is the proportion of positive locations that were correctly classified by the model. Sensitivity is also known as the true positive rate and can be thought of as the degree of absence of omission errors. Specificity is the proportion of random locations chosen from the background (these pseudo-absences are used instead of true negative locations) that were correctly classified by the model as negative. One minus the Specificity (plotted on the x-axis) is known as the false positive rate and represents the commission error rate. 

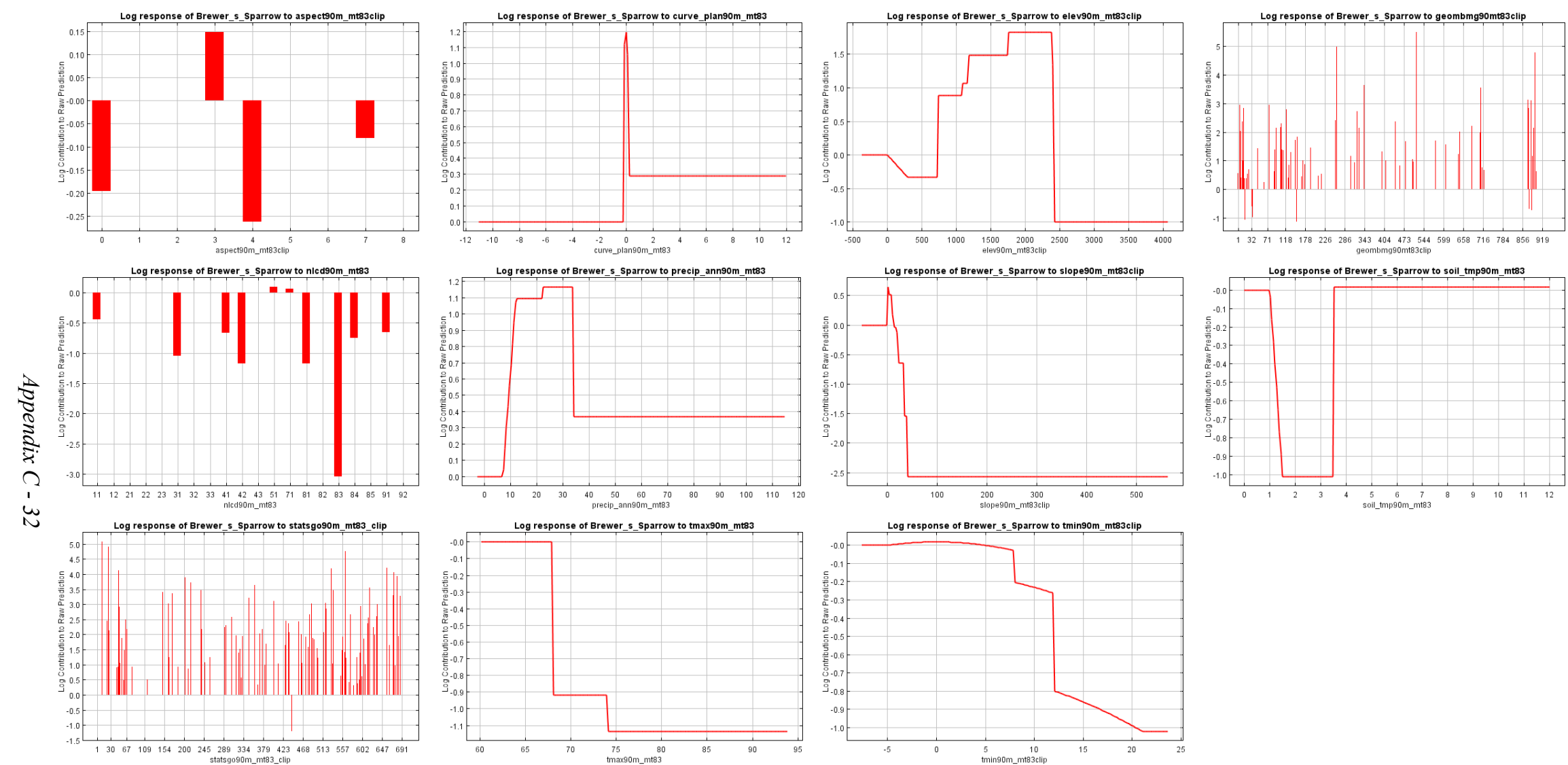

Figure C25. Response curves for individual environmental variables showing how the logistic prediction changes as each environmental variable is varied while all other environmental variables are held constant at their average sample values. The value on the y-axis is predicted probability of suitable conditions as given by the logistic formula $P(x)$ $=\exp (c 1 * f 1(x)+c 2 * f 2(x)+c 3 * f 3(x) \ldots) / Z$. Note that if any of the environmental variables are correlated, the marginal response curves can be misleading (e.g., two highly correlated variables with opposite response curves could effectively cancel each other out). Value definitions and/or links to metadata containing these definitions can be found in the Descriptions of Environmental Input Layers section of the appendix above. 


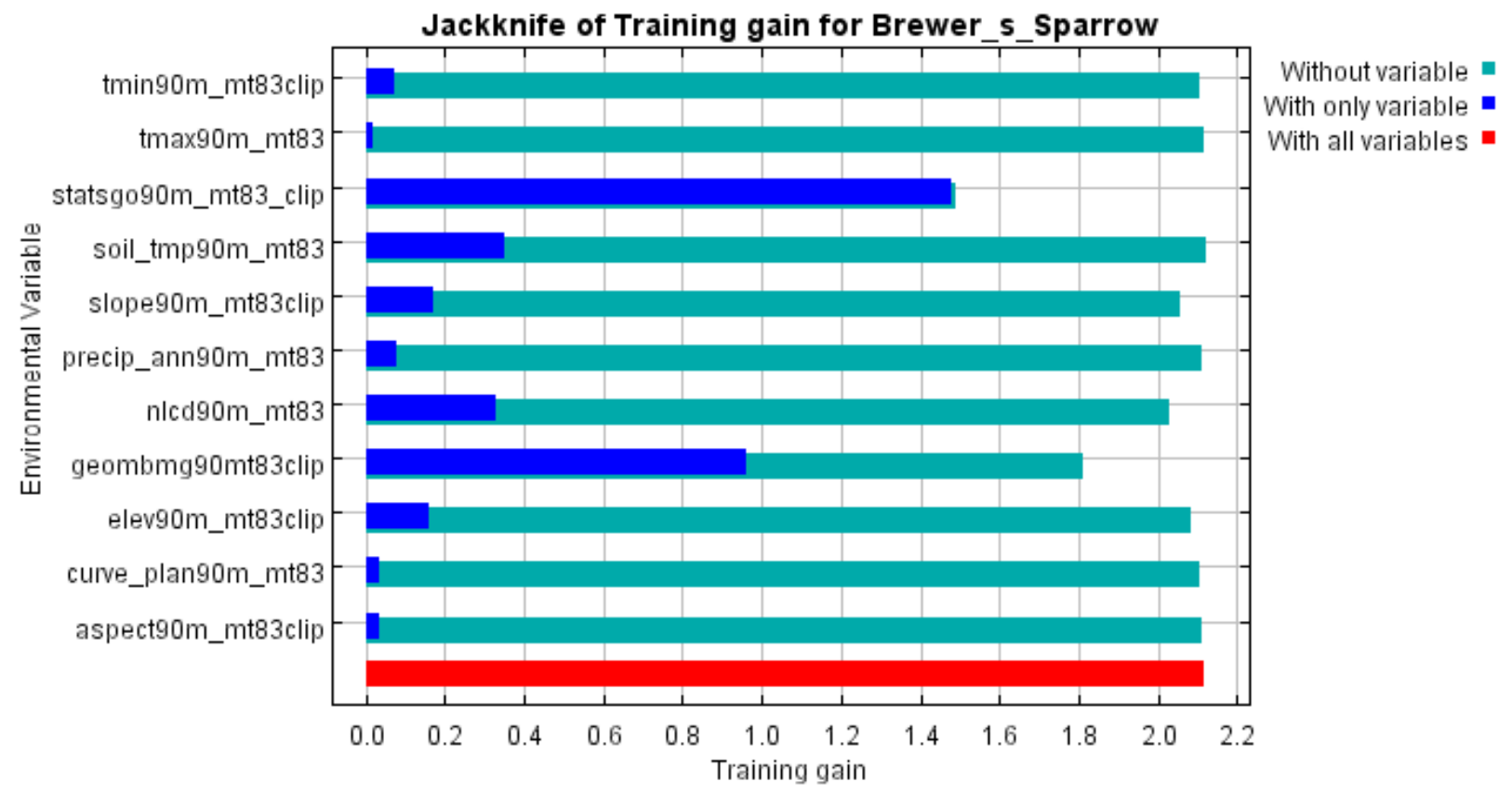

Figure C26. Jackknife chart showing the relative importance of environmental variables as a function of the change in "gain" (the log of the number of grid cells minus the average of the negative log probabilities of the sample locations) resulting from the exclusion or sole inclusion of the environmental variable in the model. Variables with the highest training gain resulting from sole inclusion of those variables (dark blue bars) are the best individual variables at describing suitable habitat for the species. Variables with the greatest reduction in training gain resulting from their exclusion (light blue bars) contain information on the species habitat use that is not present in other variables. The red bar indicates the maximum gain achieved with inclusion of all variables. 


\section{Lark Bunting (Calamospiza melanocorys)}

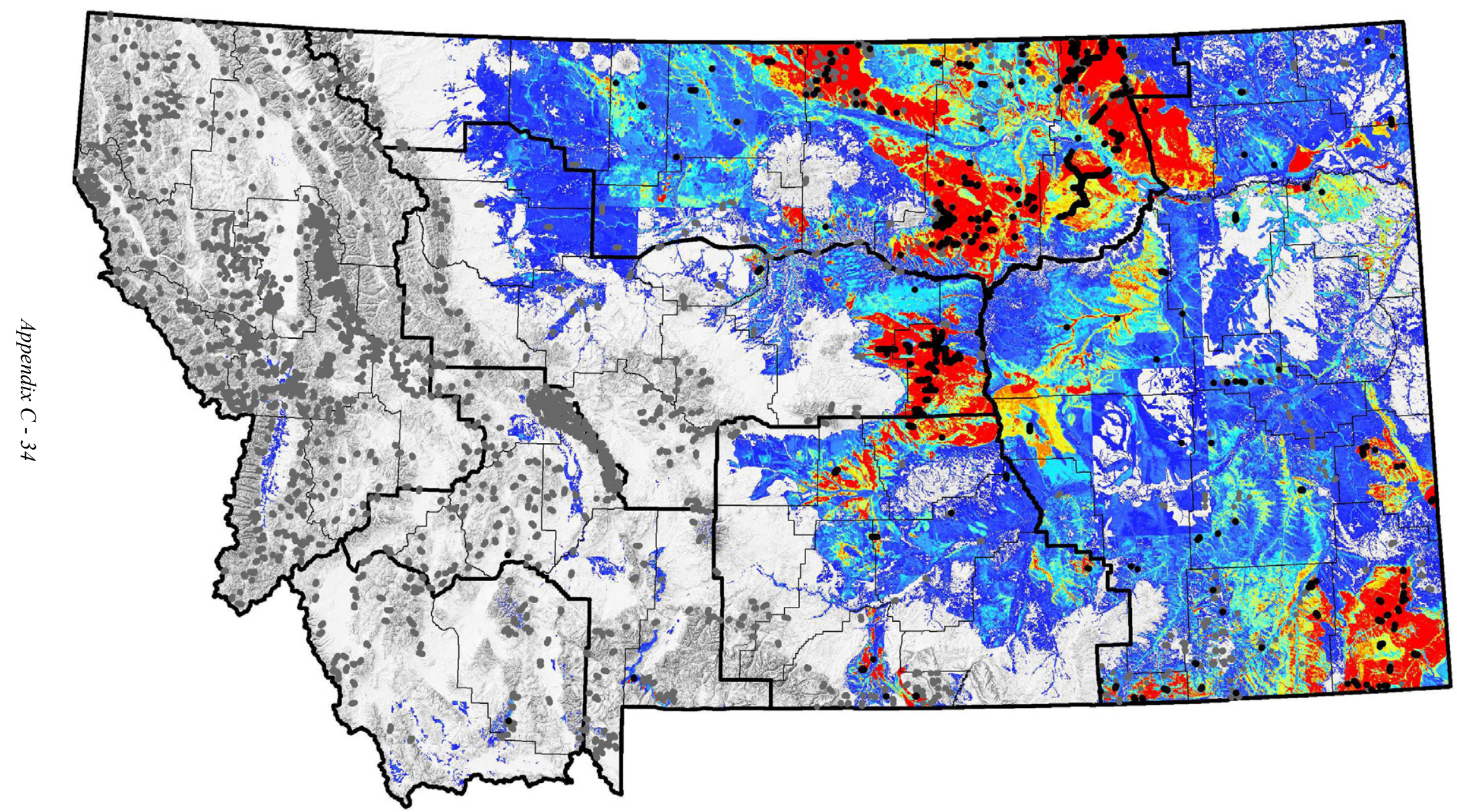

Figure C27. The hot-to-cold color map indicates the suitability of each grid cell as a function of the environmental variables at that grid cell. Hotter colors indicate areas that are predicted to have more suitable habitat for the species. Black dots are positive data used to build the model. Gray dots are locations where a survey capable of detecting the species has been performed. A shaded relief map, BLM Field Office boundaries, and county lines are included for reference. 


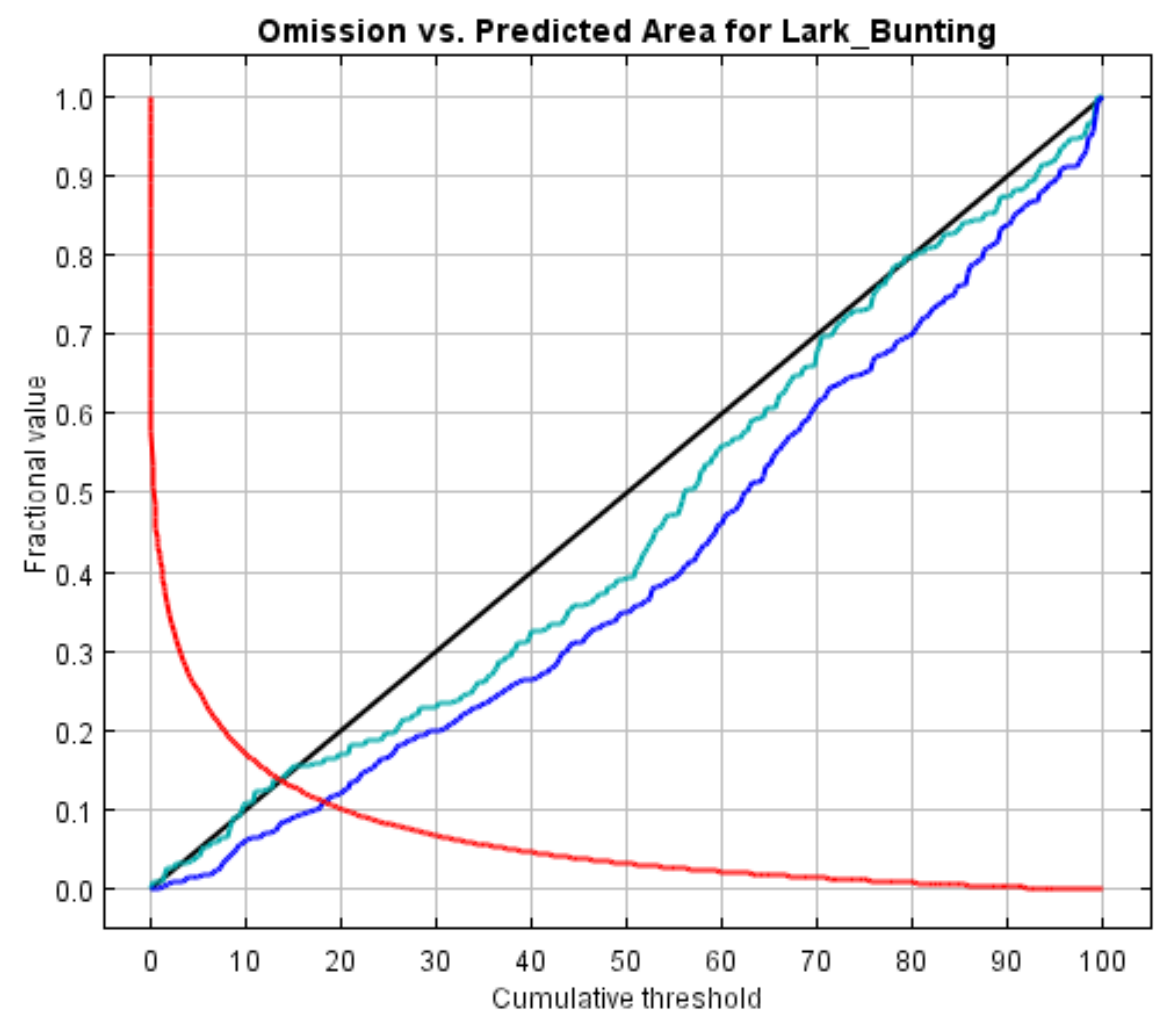

Fraction of background predicted Omission on training samples Omission on test samples Predicted omission -

Figure C28. An evaluation of omission error rates for training (dark blue line) and test (light blue line) data as a function of the cumulative threshold and overall predicted area. The red line indicates the overall fraction of the map area fitting each value of the cumulative threshold. The black line is the predicted omission rate for each cumulative threshold. 


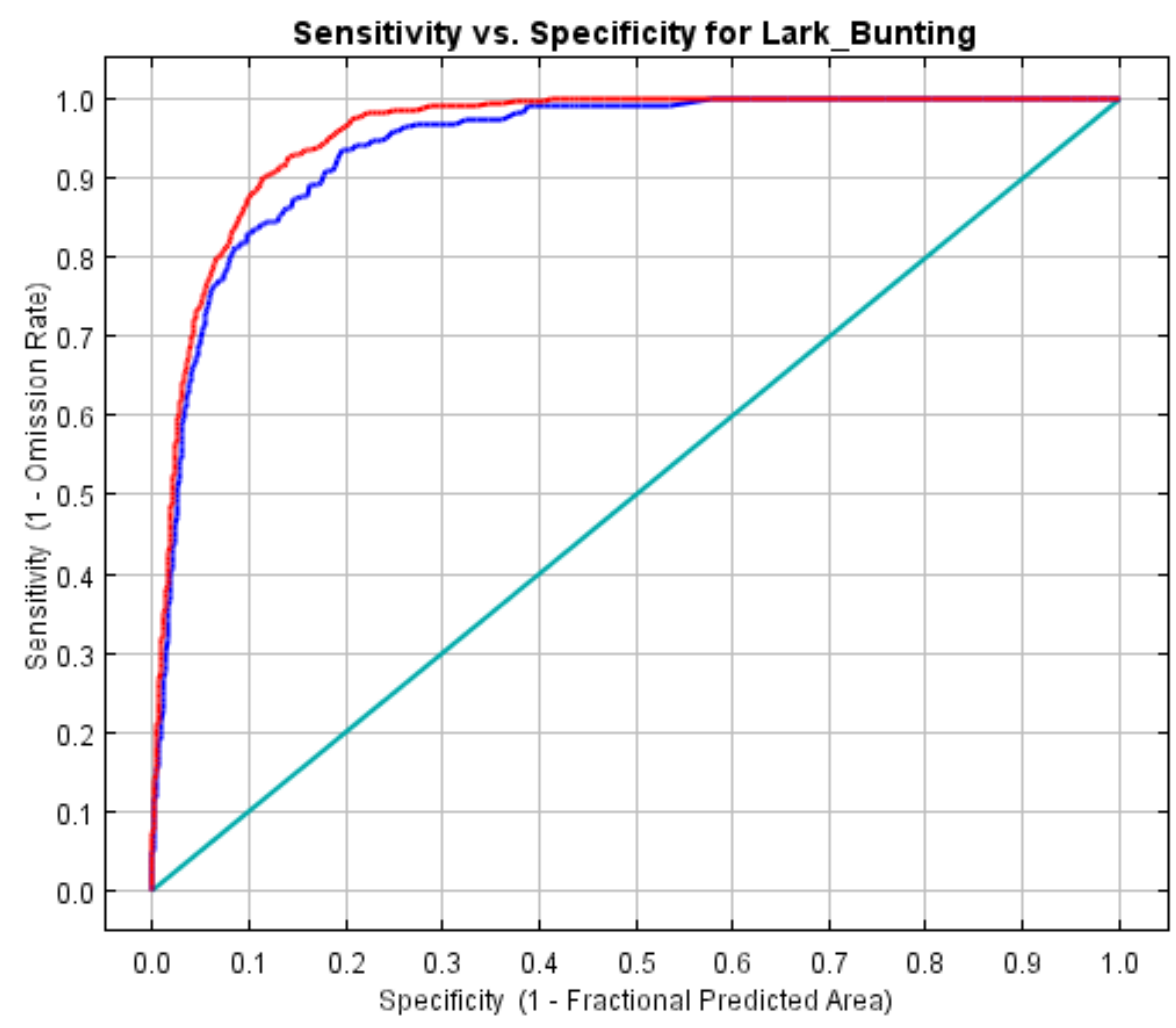

Training data $(\mathrm{AUC}=0.956)$.

Test data $(A \cup C=0.940)$ -

Random Prediction (AUC $=0.5)$

Figure C29. Receiver Operating Characteristic (ROC) curve evaluating the overall predictive power of the model with the Area Under the Curve (AUC). The AUC value indicates that when two random locations are chosen the model has that probability of assigning a higher cumulative threshold value to the location with more suitable habitat. The light blue line indicates how a neutral or random model would perform (i.e., it only has a 50\% probability of assigning a higher cumulative threshold value to a random location with more suitable habitat than a random location with less suitable habitat). The further toward the top left of the graph the training (red) and test (blue) data lines are, the better the model is at predicting the presences contained in the training data. Sensitivity (plotted on the y-axis) is the proportion of positive locations that were correctly classified by the model. Sensitivity is also known as the true positive rate and can be thought of as the degree of absence of omission errors. Specificity is the proportion of random locations chosen from the background (these pseudo-absences are used instead of true negative locations) that were correctly classified by the model as negative. One minus the Specificity (plotted on the x-axis) is known as the false positive rate and represents the commission error rate. 

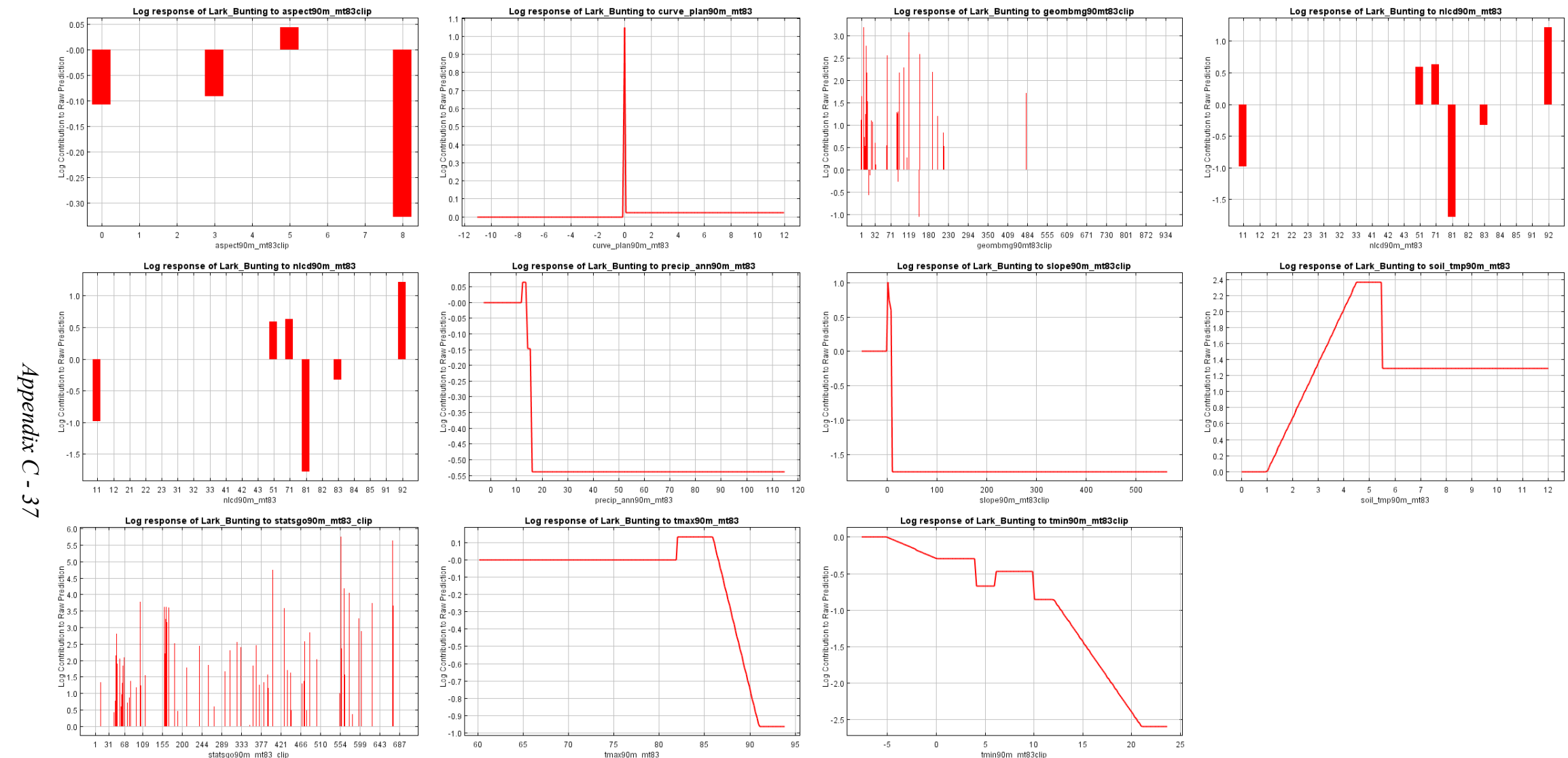

Figure C30. Response curves for individual environmental variables showing how the logistic prediction changes as each environmental variable is varied while all other environmental variables are held constant at their average sample values. The value on the $y$-axis is predicted probability of suitable conditions as given by the logistic formula $P(x)$ $=\exp (c 1 * f 1(x)+c 2 * f 2(x)+c 3 * f 3(x) \ldots) / Z$. Note that if any of the environmental variables are correlated, the marginal response curves can be misleading (e.g., two highly correlated variables with opposite response curves could effectively cancel each other out). Value definitions and/or links to metadata containing these definitions can be found in the Descriptions of Environmental Input Layers section of the appendix above. 


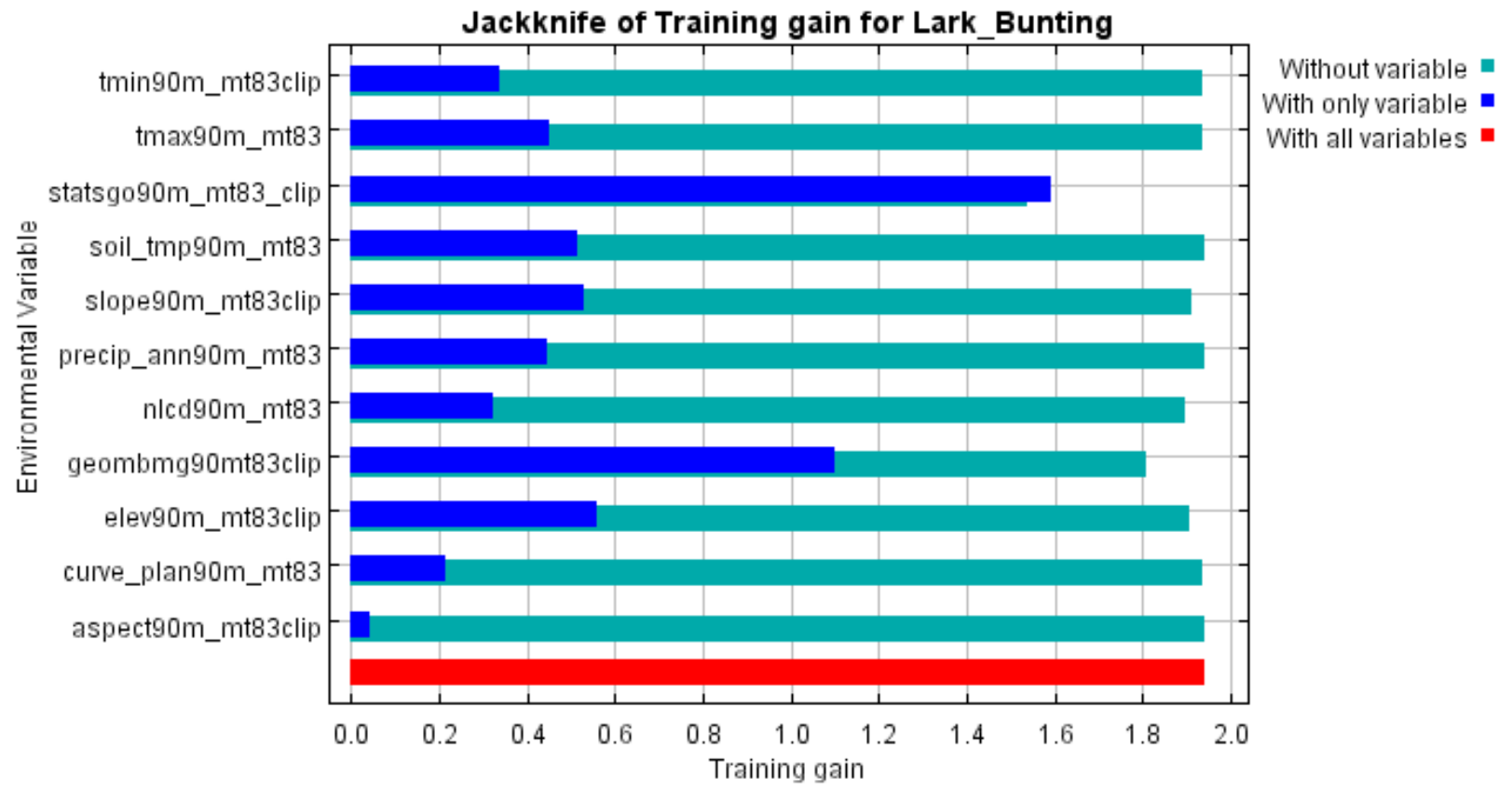

Figure C31. Jackknife chart showing the relative importance of environmental variables as a function of the change in "gain" (the log of the number of grid cells minus the average of the negative log probabilities of the sample locations) resulting from the exclusion or sole inclusion of the environmental variable in the model. Variables with the highest training gain resulting from sole inclusion of those variables (dark blue bars) are the best individual variables at describing suitable habitat for the species. Variables with the greatest reduction in training gain resulting from their exclusion (light blue bars) contain information on the species habitat use that is not present in other variables. The red bar indicates the maximum gain achieved with inclusion of all variables. 


\section{Grasshopper Sparrow (Ammodramus savannarum)}

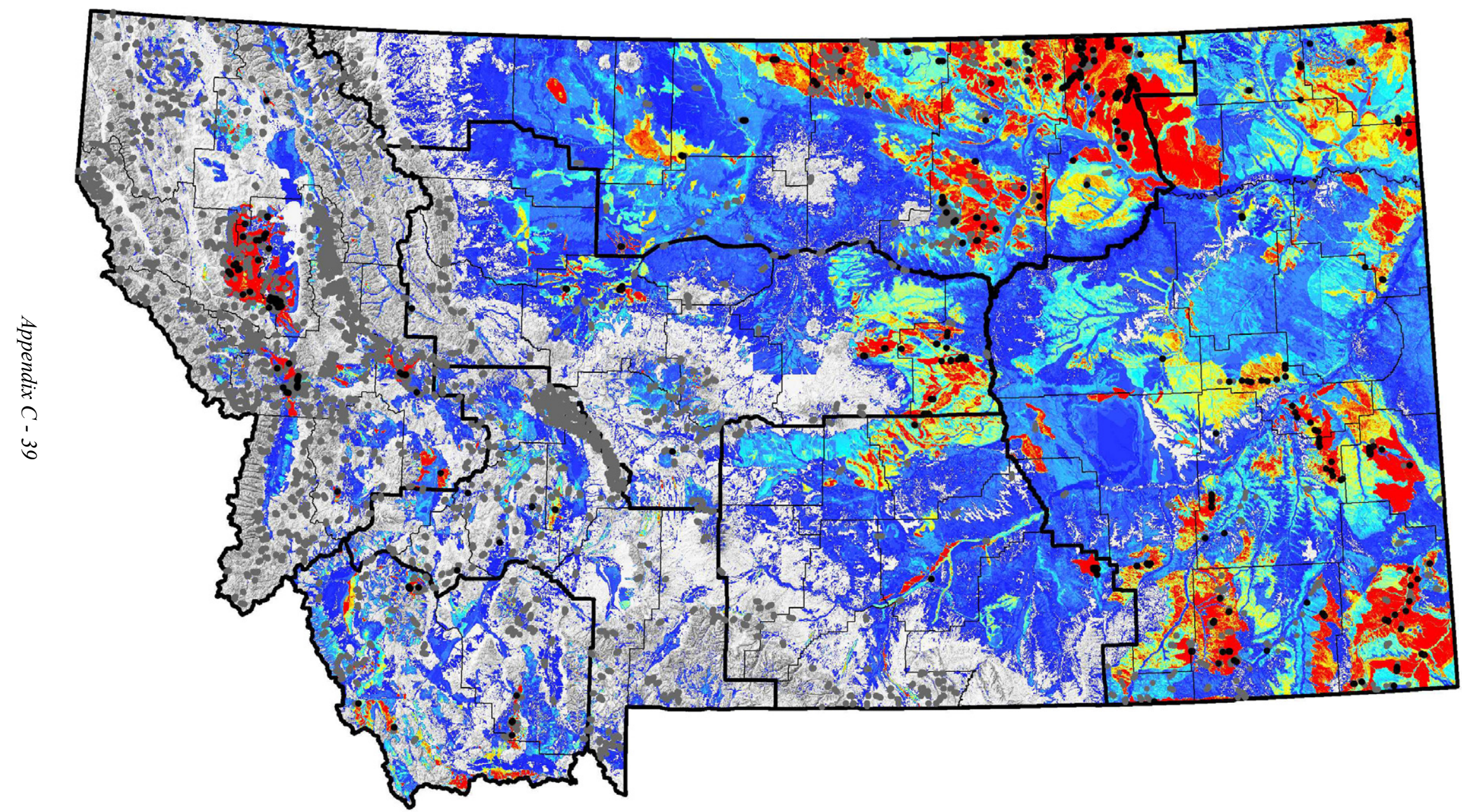

Figure C32. The hot-to-cold color map indicates the suitability of each grid cell as a function of the environmental variables at that grid cell. Hotter colors indicate areas that are predicted to have more suitable habitat for the species. Black dots are positive data used to build the model. Gray dots are locations where a survey capable of detecting the species has been performed. A shaded relief map, BLM Field Office boundaries, and county lines are included for reference. 


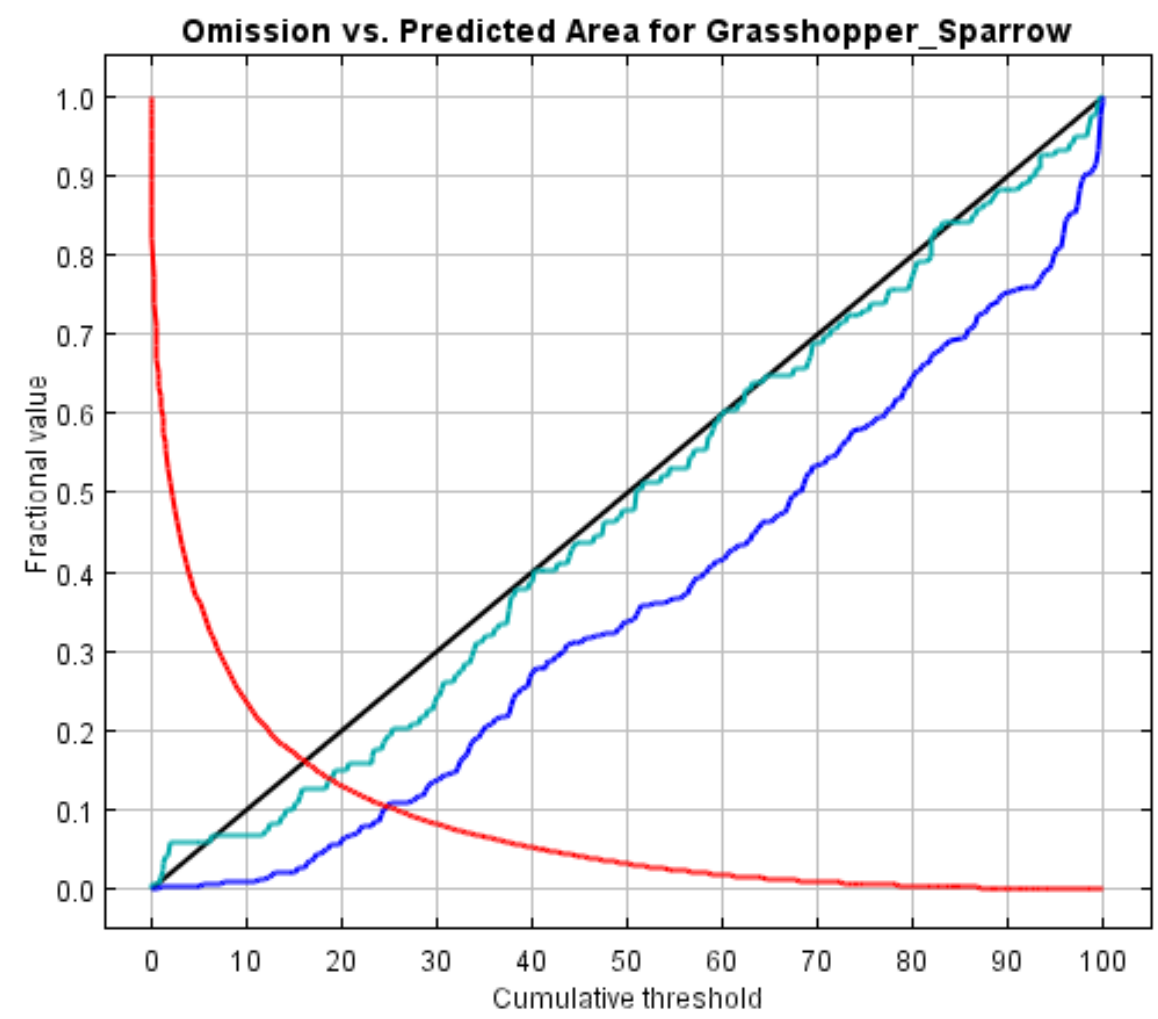

Fraction of background predicted Omission on training samples Omission on test samples Predicted omission

Figure C33. An evaluation of omission error rates for training (dark blue line) and test (light blue line) data as a function of the cumulative threshold and overall predicted area. The red line indicates the overall fraction of the map area fitting each value of the cumulative threshold. The black line is the predicted omission rate for each cumulative threshold. 


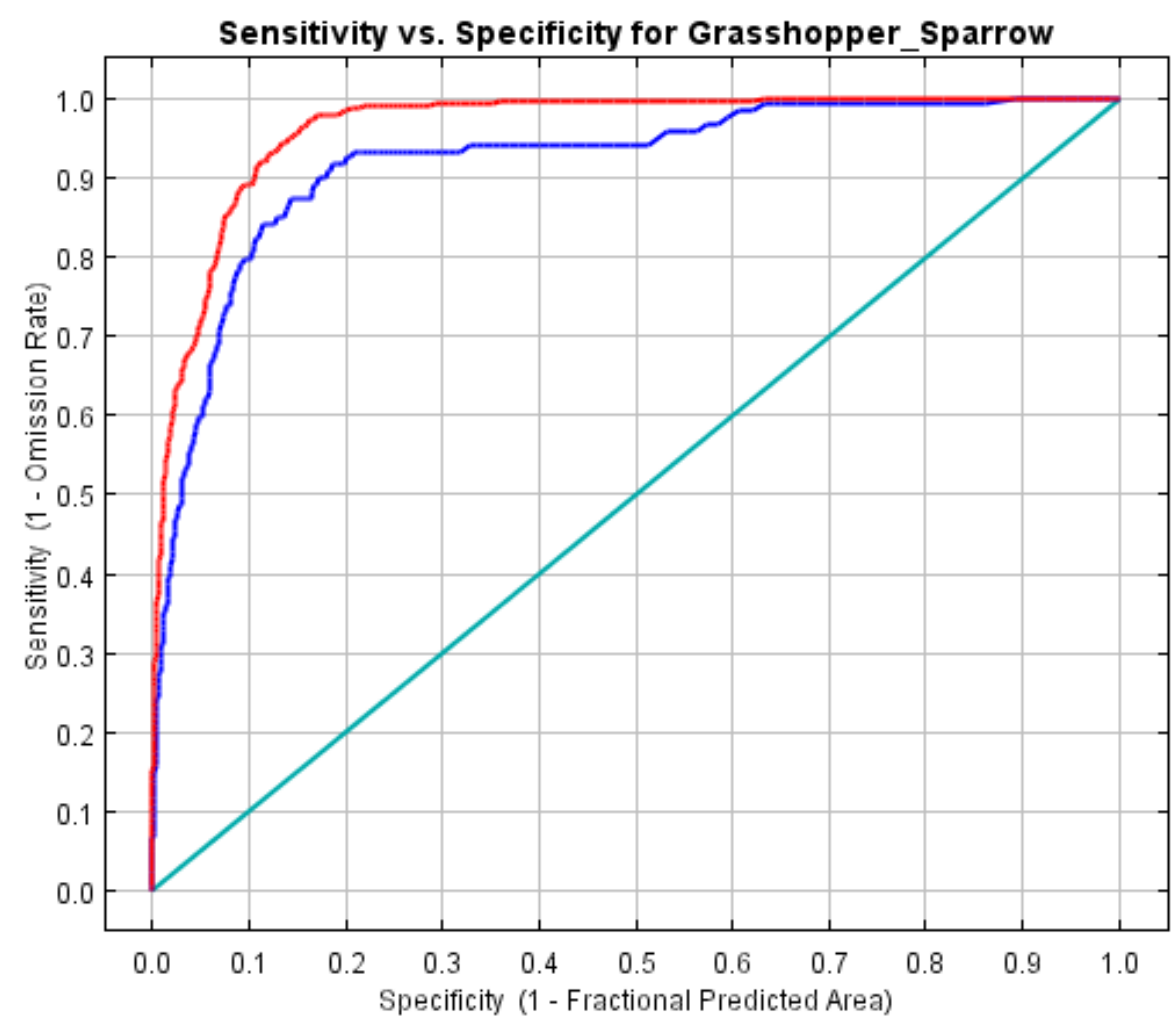

Training data $(A \cup C=0.963)$
Test data $(A \cup C=0.919)$
Random Prediction $(A \cup C=0.5)$

Figure C34. Receiver Operating Characteristic (ROC) curve evaluating the overall predictive power of the model with the Area Under the Curve (AUC). The AUC value indicates that when two random locations are chosen the model has that probability of assigning a higher cumulative threshold value to the location with more suitable habitat. The light blue line indicates how a neutral or random model would perform (i.e., it only has a 50\% probability of assigning a higher cumulative threshold value to a random location with more suitable habitat than a random location with less suitable habitat). The further toward the top left of the graph the training (red) and test (blue) data lines are, the better the model is at predicting the presences contained in the training data. Sensitivity (plotted on the y-axis) is the proportion of positive locations that were correctly classified by the model. Sensitivity is also known as the true positive rate and can be thought of as the degree of absence of omission errors. Specificity is the proportion of random locations chosen from the background (these pseudo-absences are used instead of true negative locations) that were correctly classified by the model as negative. One minus the Specificity (plotted on the x-axis) is known as the false positive rate and represents the commission error rate. 

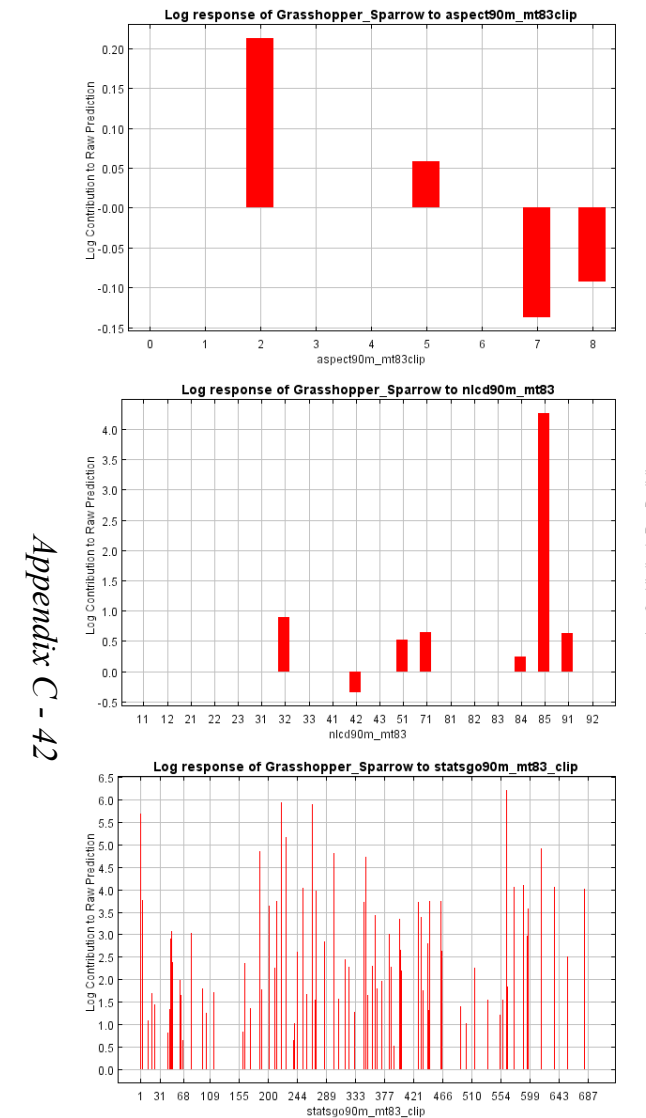

Log response of Grasshopper_sparrow to curve_plangom_mim3

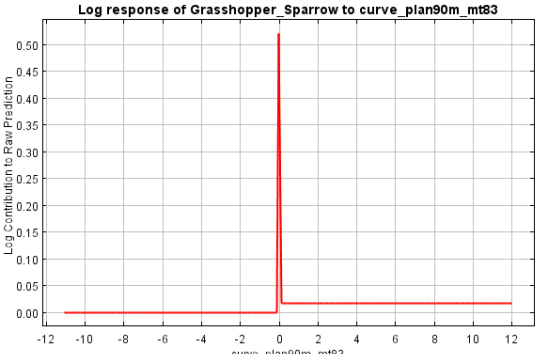

Log response of Grasshopper__Sparrow to precip_ann9om_mas
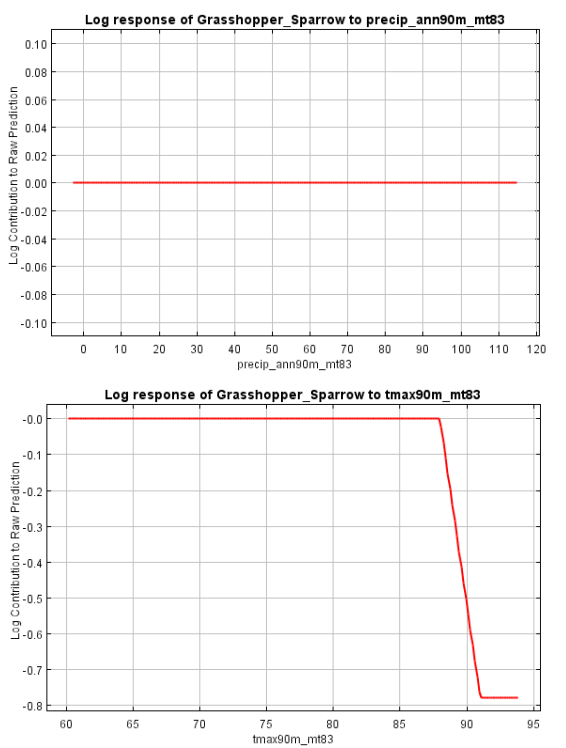
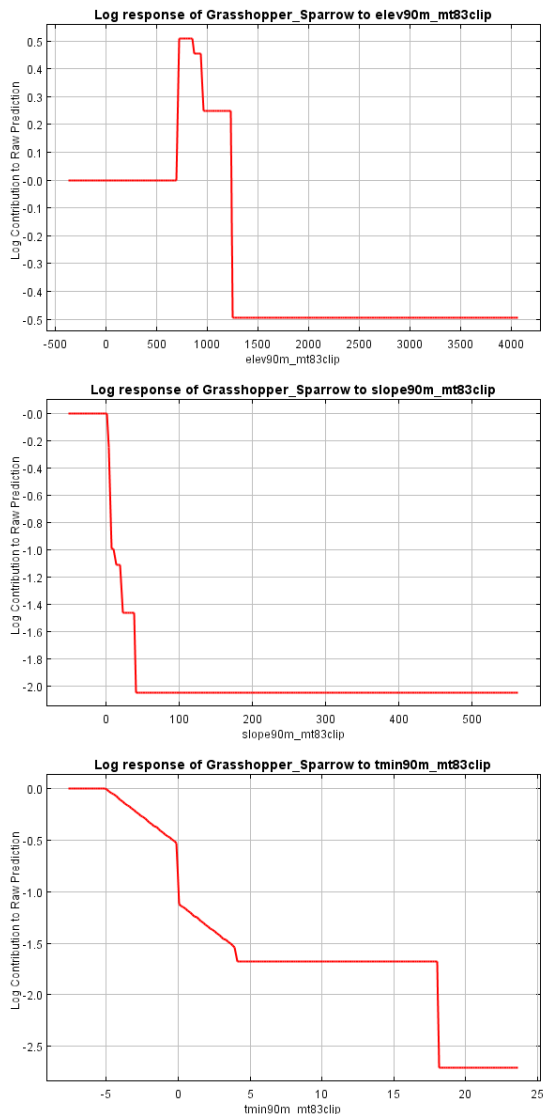
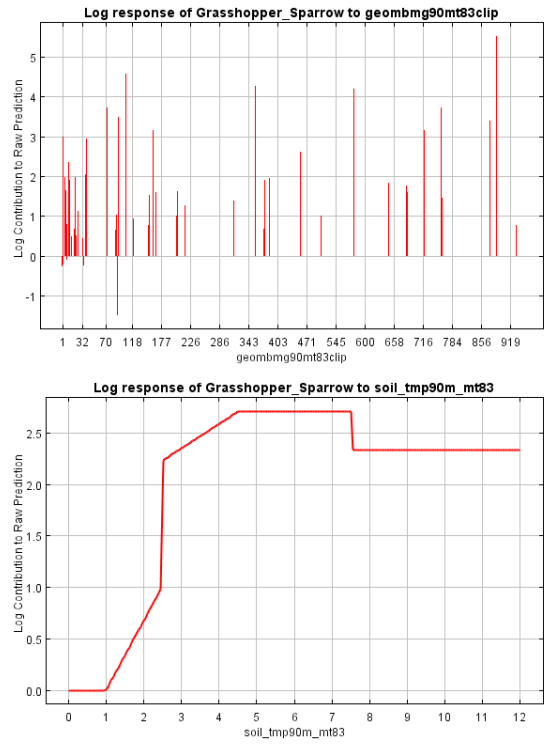

Figure C35. Response curves for individual environmental variables showing how the logistic prediction changes as each environmental variable is varied while all other environmental variables are held constant at their average sample values. The value on the $y$-axis is predicted probability of suitable conditions as given by the logistic formula $P(x)$ $=\exp (c 1 * f 1(x)+c 2 * f 2(x)+c 3 * f 3(x) \ldots) / Z$. Note that if any of the environmental variables are correlated, the marginal response curves can be misleading (e.g., two highly correlated variables with opposite response curves could effectively cancel each other out). Value definitions and/or links to metadata containing these definitions can be found in the Descriptions of Environmental Input Layers section of the appendix above. 


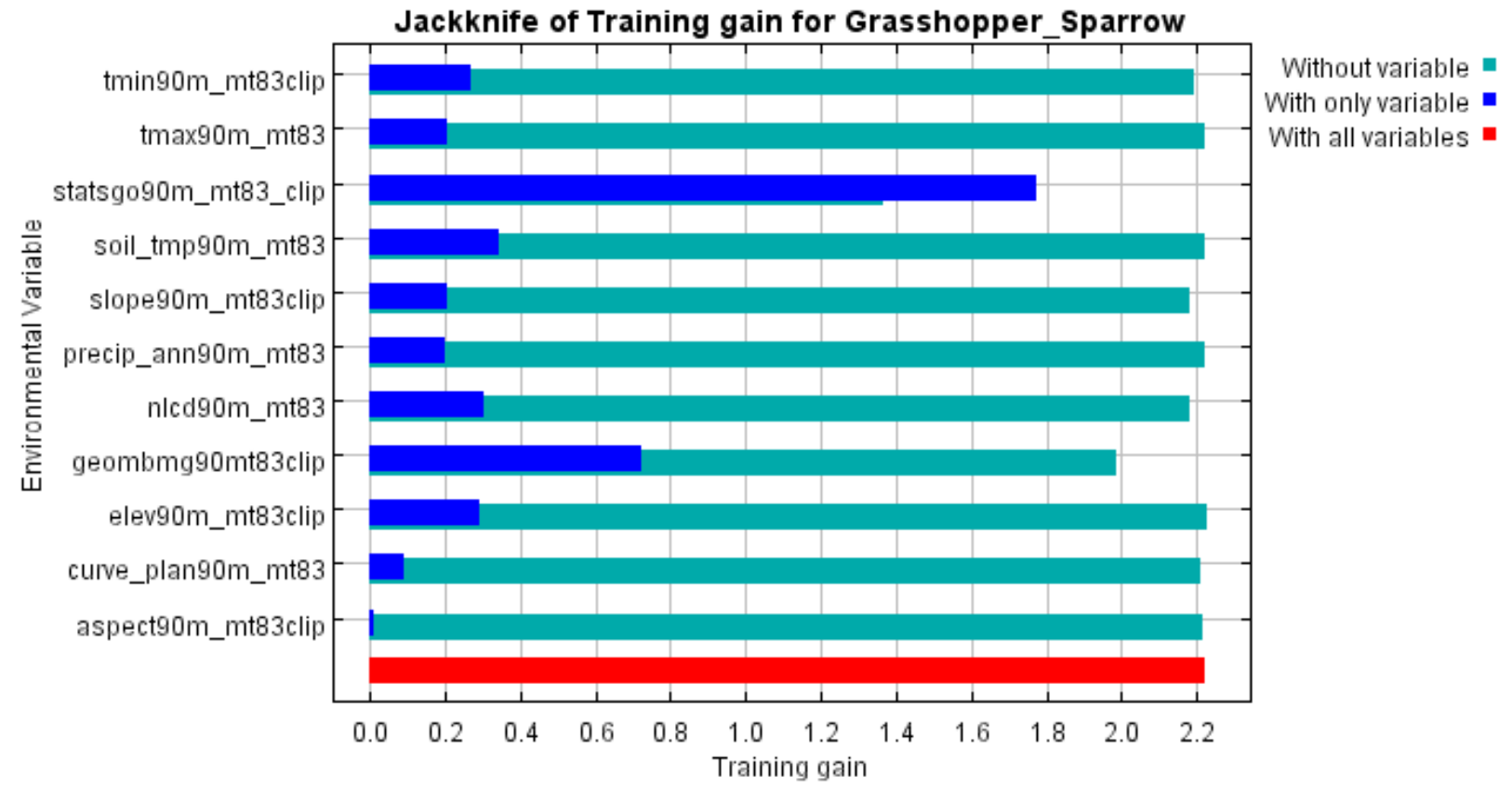

Figure C36. Jackknife chart showing the relative importance of environmental variables as a function of the change in "gain" (the log of the number of grid cells minus the average of the negative log probabilities of the sample locations) resulting from the exclusion or sole inclusion of the environmental variable in the model. Variables with the highest training gain resulting from sole inclusion of those variables (dark blue bars) are the best individual variables at describing suitable habitat for the species. Variables with the greatest reduction in training gain resulting from their exclusion (light blue bars) contain information on the species habitat use that is not present in other variables. The red bar indicates the maximum gain achieved with inclusion of all variables. 


\section{Baird's Sparrow (Ammodramus bairdii)}

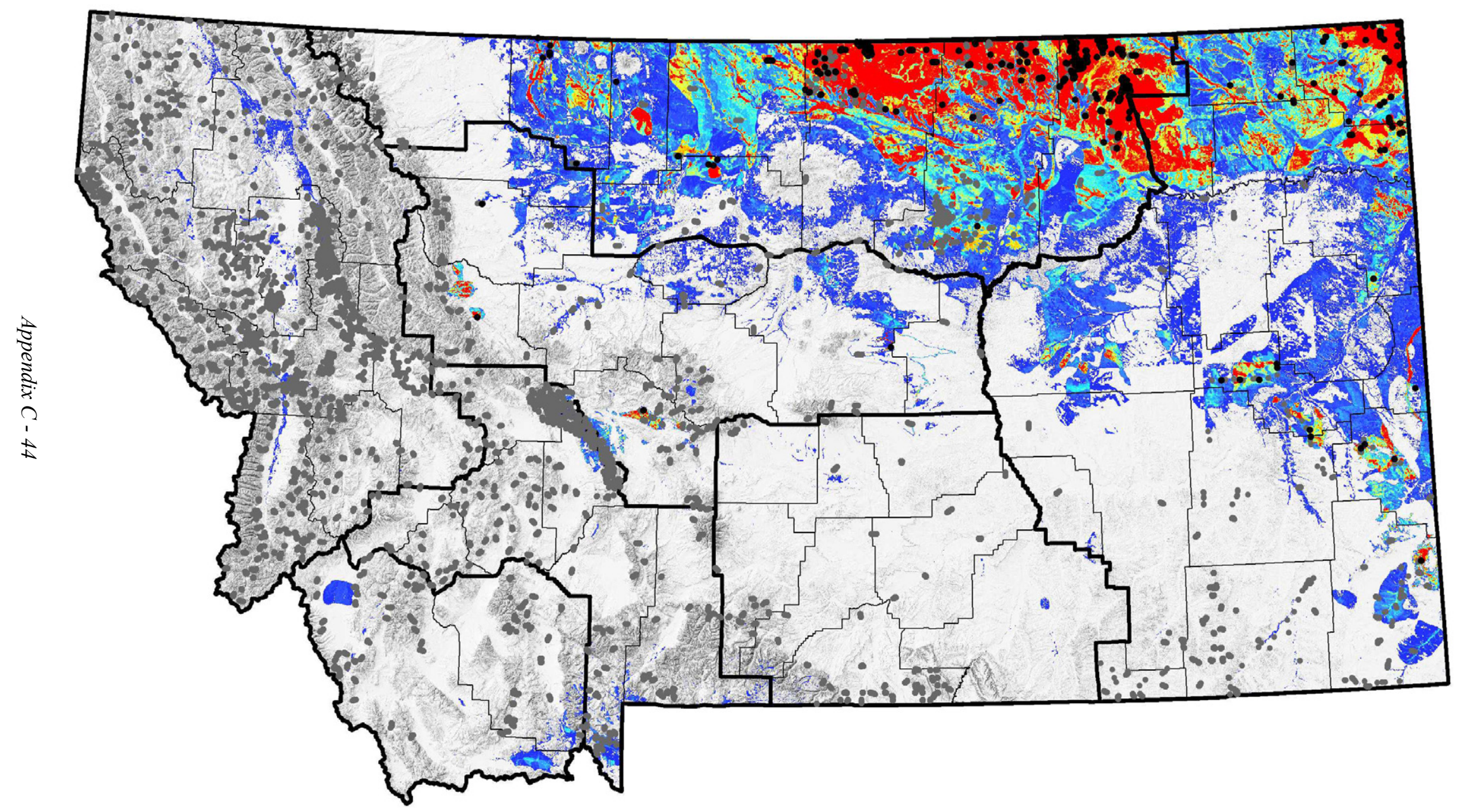

Figure C37. The hot-to-cold color map indicates the suitability of each grid cell as a function of the environmental variables at that grid cell. Hotter colors indicate areas that are predicted to have more suitable habitat for the species. Black dots are positive data used to build the model. Gray dots are locations where a survey capable of detecting the species has been performed. A shaded relief map, BLM Field Office boundaries, and county lines are included for reference. 


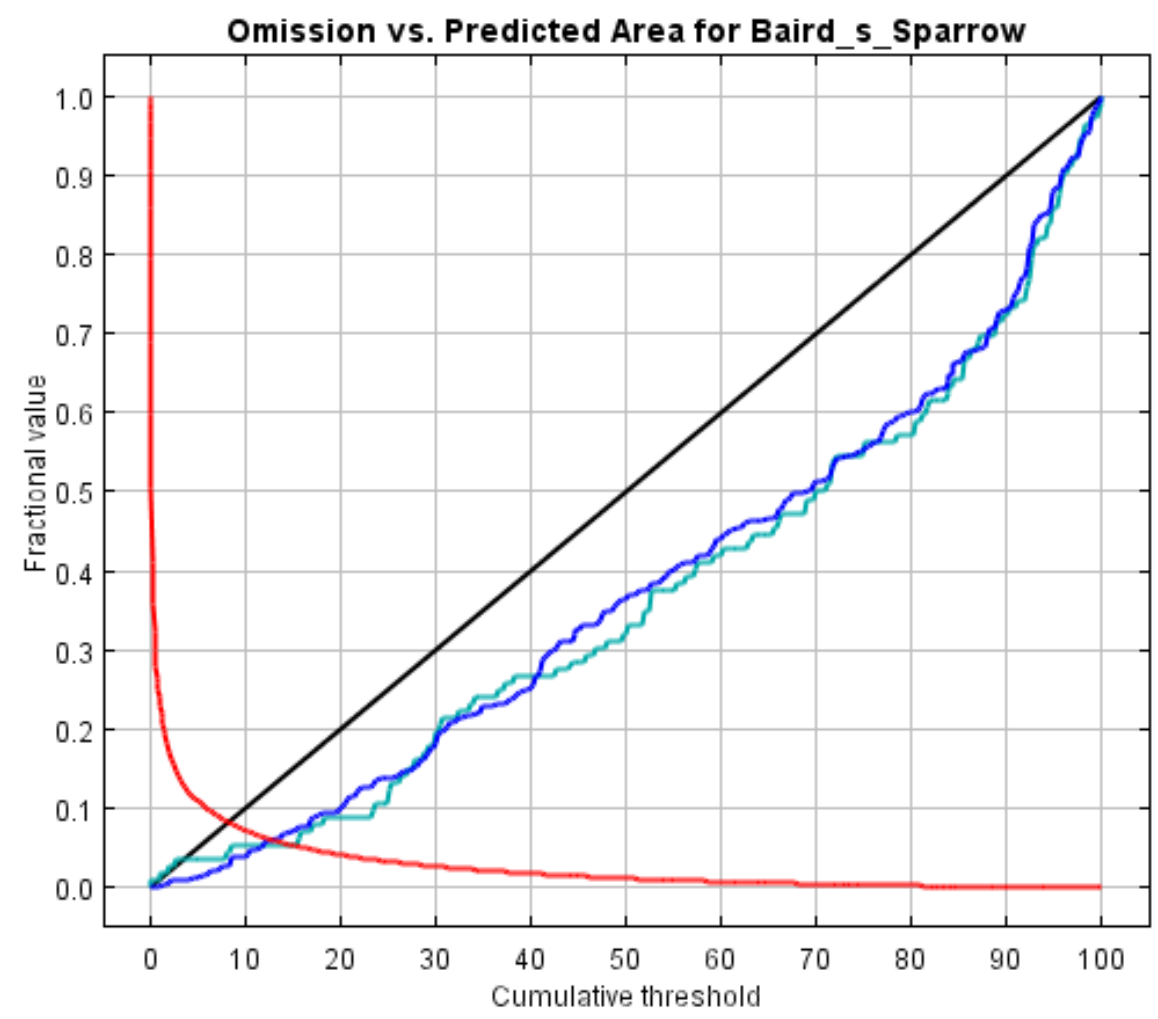

Fraction of background predicted $\mathbf{m}$ Omission on training samples Omission on test samples Predicted omission

Figure C38. An evaluation of omission error rates for training (dark blue line) and test (light blue line) data as a function of the cumulative threshold and overall predicted area. The red line indicates the overall fraction of the map area fitting each value of the cumulative threshold. The black line is the predicted omission rate for each cumulative threshold. 


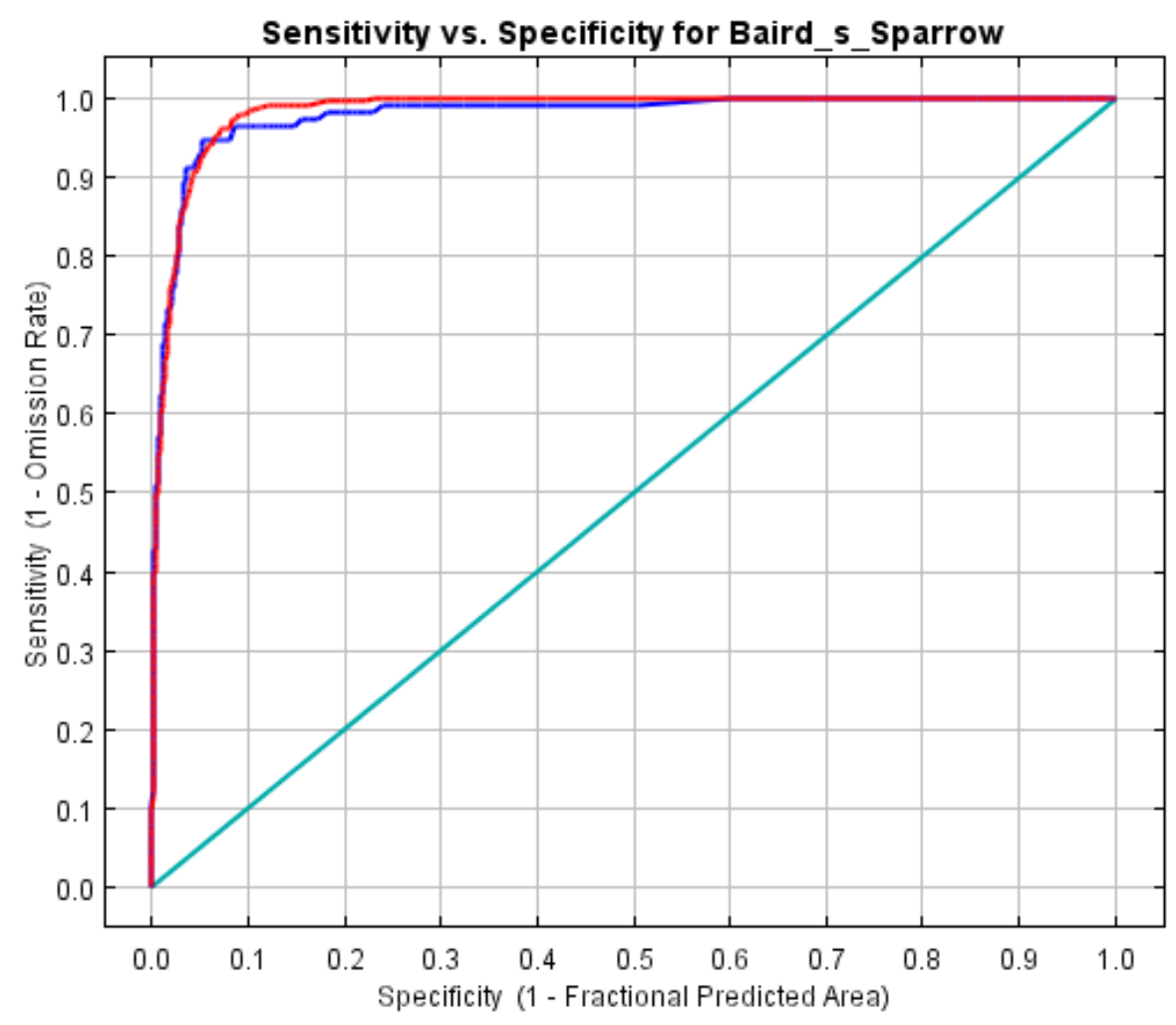

Training data $(A \cup C=0.984)$
Test data $(A \cup C=0.979)$
Random Prediction $(A \cup C=0.5)$

Figure C39. Receiver Operating Characteristic (ROC) curve evaluating the overall predictive power of the model with the Area Under the Curve (AUC). The AUC value indicates that when two random locations are chosen the model has that probability of assigning a higher cumulative threshold value to the location with more suitable habitat. The light blue line indicates how a neutral or random model would perform (i.e., it only has a 50\% probability of assigning a higher cumulative threshold value to a random location with more suitable habitat than a random location with less suitable habitat). The further toward the top left of the graph the training (red) and test (blue) data lines are, the better the model is at predicting the presences contained in the training data. Sensitivity (plotted on the y-axis) is the proportion of positive locations that were correctly classified by the model. Sensitivity is also known as the true positive rate and can be thought of as the degree of absence of omission errors. Specificity is the proportion of random locations chosen from the background (these pseudo-absences are used instead of true negative locations) that were correctly classified by the model as negative. One minus the Specificity (plotted on the $x$-axis) is known as the false positive rate and represents the commission error rate. 

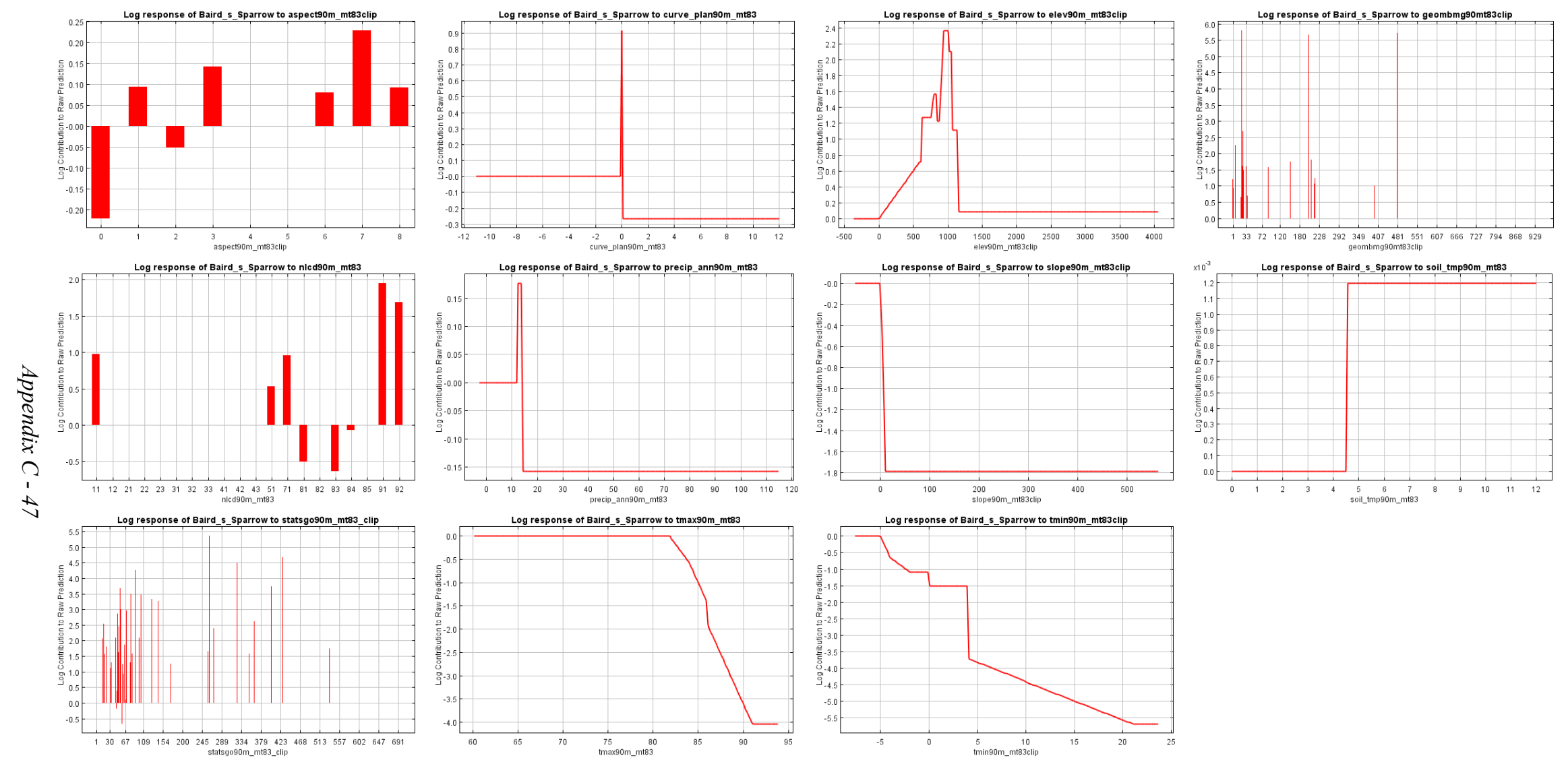

Figure C40. Response curves for individual environmental variables showing how the logistic prediction changes as each environmental variable is varied while all other environmental variables are held constant at their average sample values. The value on the $y$-axis is predicted probability of suitable conditions as given by the logistic formula $P(x)$ $=\exp (c 1 * f 1(x)+c 2 * f 2(x)+c 3 * f 3(x) \ldots) / Z$. Note that if any of the environmental variables are correlated, the marginal response curves can be misleading (e.g., two highly correlated variables with opposite response curves could effectively cancel each other out). Value definitions and/or links to metadata containing these definitions can be found in the Descriptions of Environmental Input Layers section of the appendix above. 


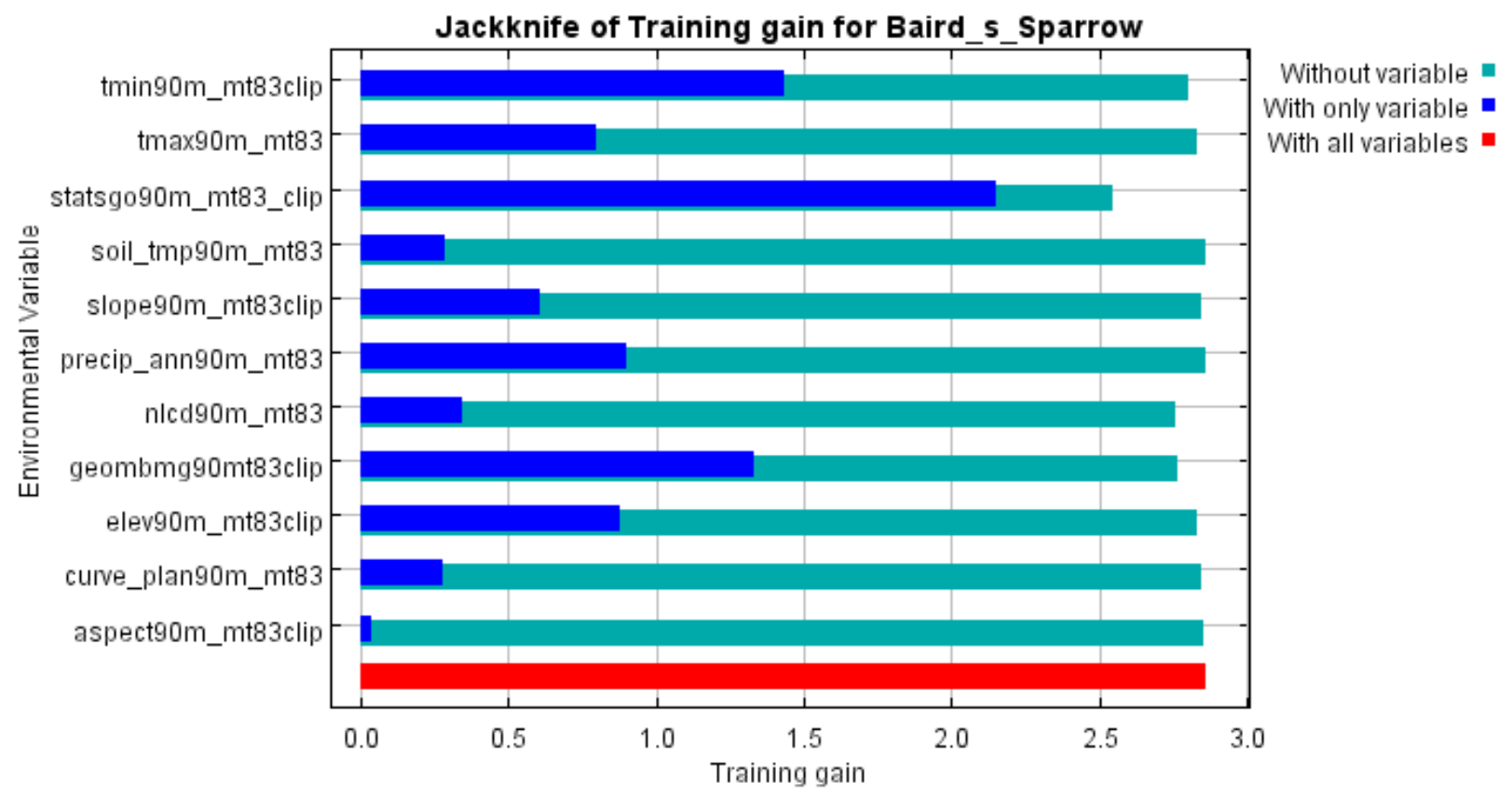

Figure C41. Jackknife chart showing the relative importance of environmental variables as a function of the change in "gain" (the log of the number of grid cells minus the average of the negative log probabilities of the sample locations) resulting from the exclusion or sole inclusion of the environmental variable in the model. Variables with the highest training gain resulting from sole inclusion of those variables (dark blue bars) are the best individual variables at describing suitable habitat for the species. Variables with the greatest reduction in training gain resulting from their exclusion (light blue bars) contain information on the species habitat use that is not present in other variables. The red bar indicates the maximum gain achieved with inclusion of all variables. 


\section{McCown's Longspur (Calcarius mccownii)}

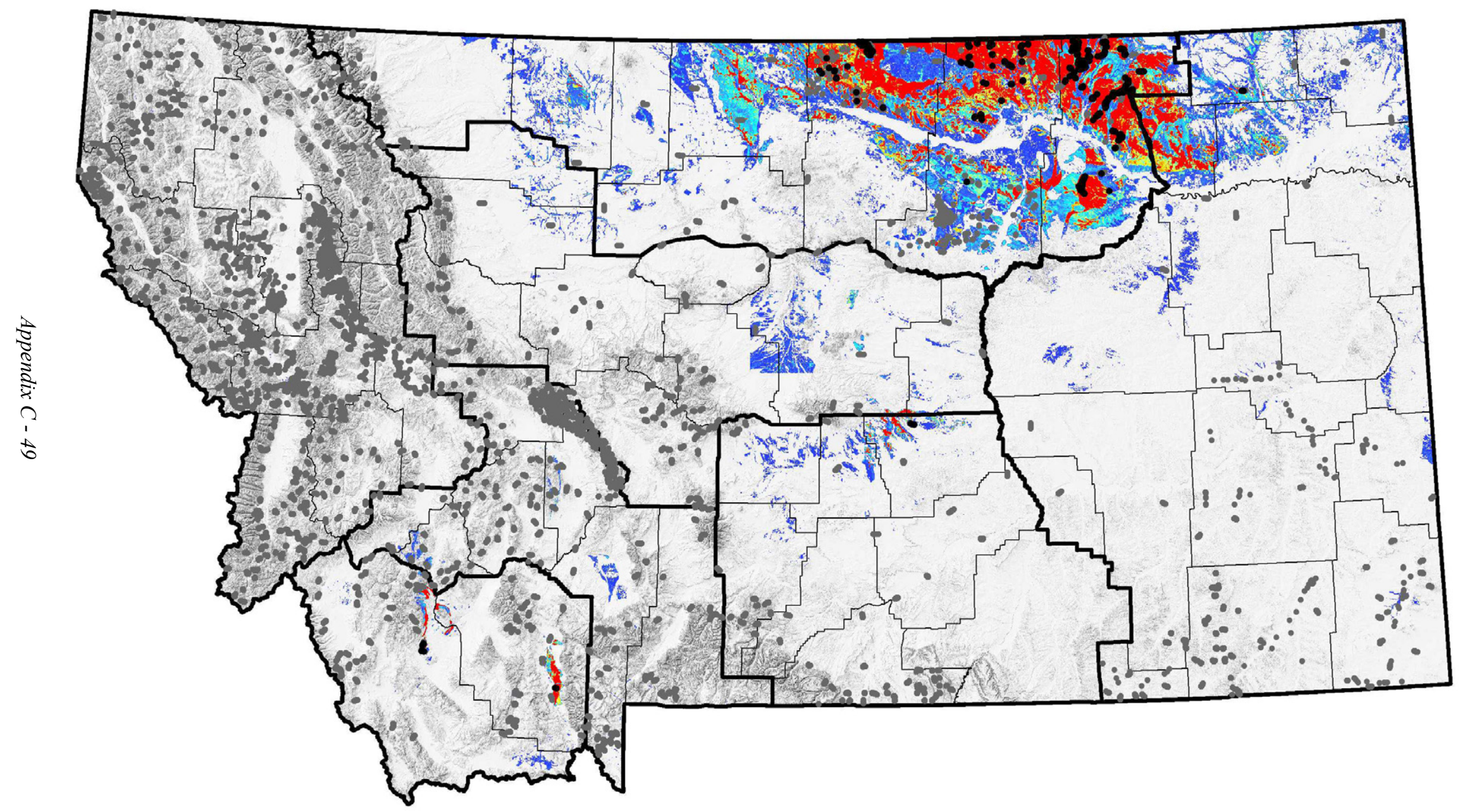

Figure C42. The hot-to-cold color map indicates the suitability of each grid cell as a function of the environmental variables at that grid cell. Hotter colors indicate areas that are predicted to have more suitable habitat for the species. Black dots are positive data used to build the model. Gray dots are locations where a survey capable of detecting the species has been performed. A shaded relief map, BLM Field Office boundaries, and county lines are included for reference. 


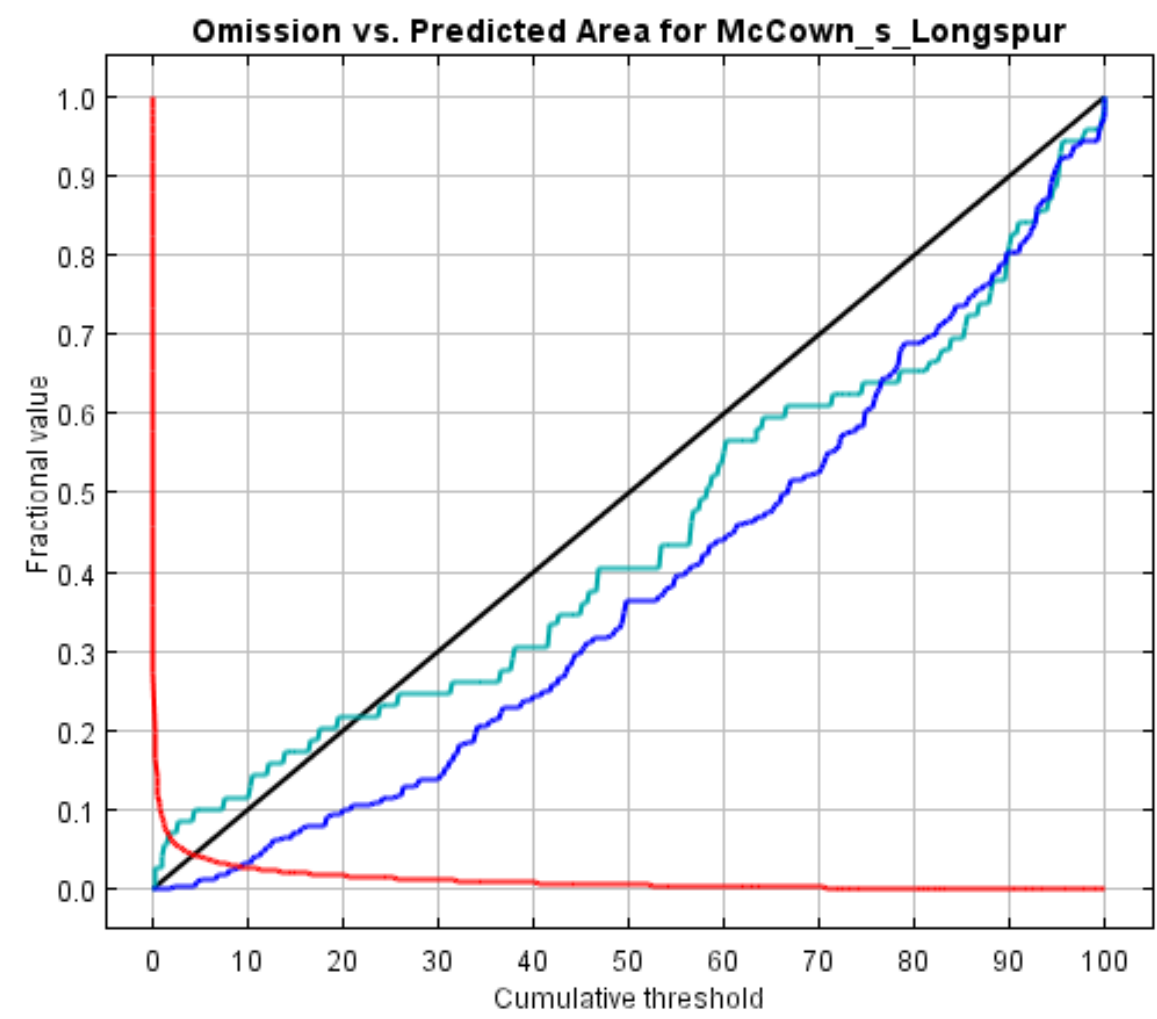

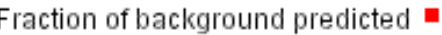
Omission on training samples Omission on test samples Predicted omission

Figure C43. An evaluation of omission error rates for training (dark blue line) and test (light blue line) data as a function of the cumulative threshold and overall predicted area. The red line indicates the overall fraction of the map area fitting each value of the cumulative threshold. The black line is the predicted omission rate for each cumulative threshold. 


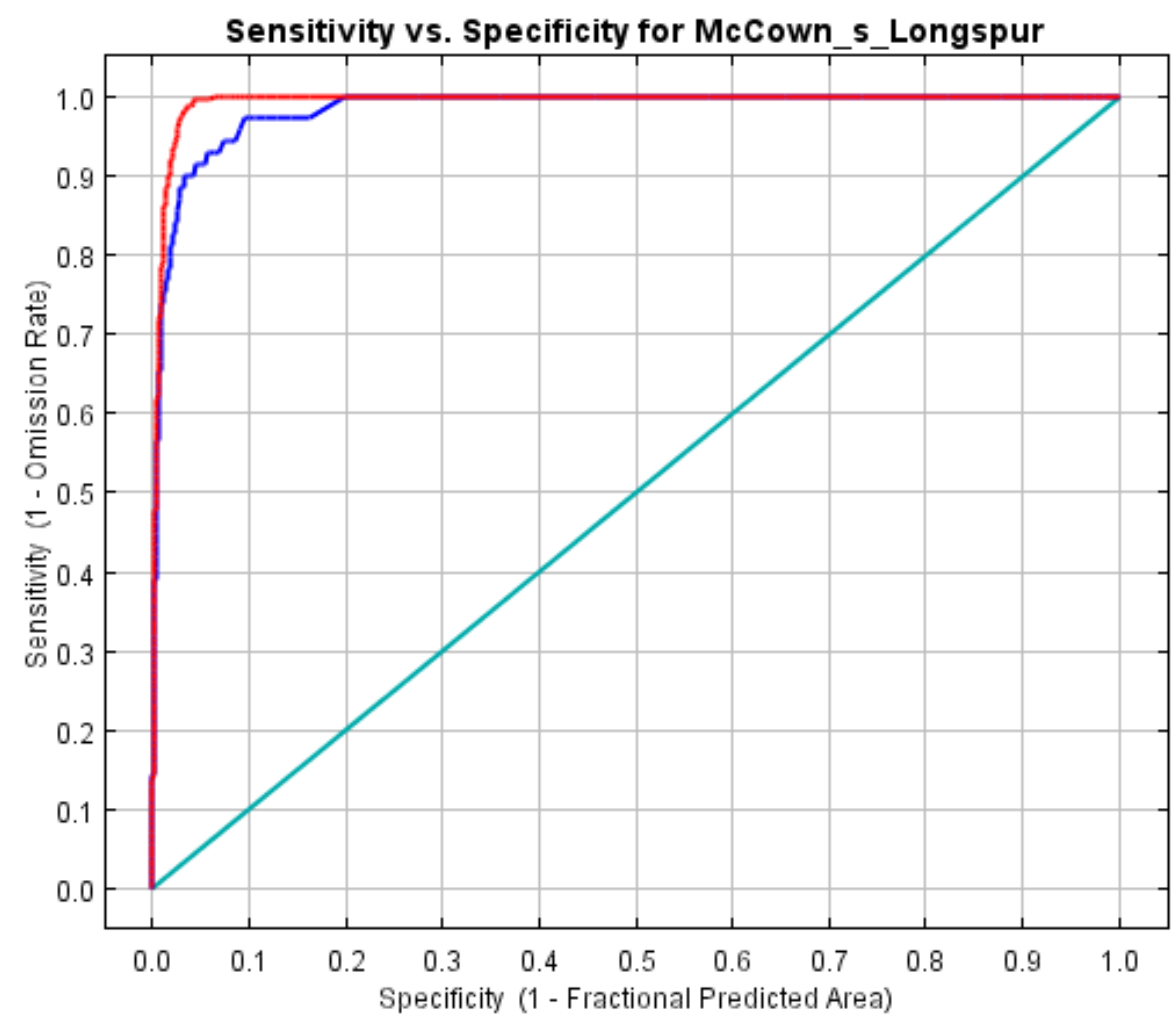

Training data $(\mathrm{AUC}=0.993)$.

Test data $(\mathrm{AUC}=0.984)$ -

Random Prediction $(\mathrm{AUC}=0.5)$

Figure C44. Receiver Operating Characteristic (ROC) curve evaluating the overall predictive power of the model with the Area Under the Curve (AUC). The AUC value indicates that when two random locations are chosen the model has that probability of assigning a higher cumulative threshold value to the location with more suitable habitat. The light blue line indicates how a neutral or random model would perform (i.e., it only has a 50\% probability of assigning a higher cumulative threshold value to a random location with more suitable habitat than a random location with less suitable habitat). The further toward the top left of the graph the training (red) and test (blue) data lines are, the better the model is at predicting the presences contained in the training data. Sensitivity (plotted on the y-axis) is the proportion of positive locations that were correctly classified by the model. Sensitivity is also known as the true positive rate and can be thought of as the degree of absence of omission errors. Specificity is the proportion of random locations chosen from the background (these pseudo-absences are used instead of true negative locations) that were correctly classified by the model as negative. One minus the Specificity (plotted on the x-axis) is known as the false positive rate and represents the commission error rate. 

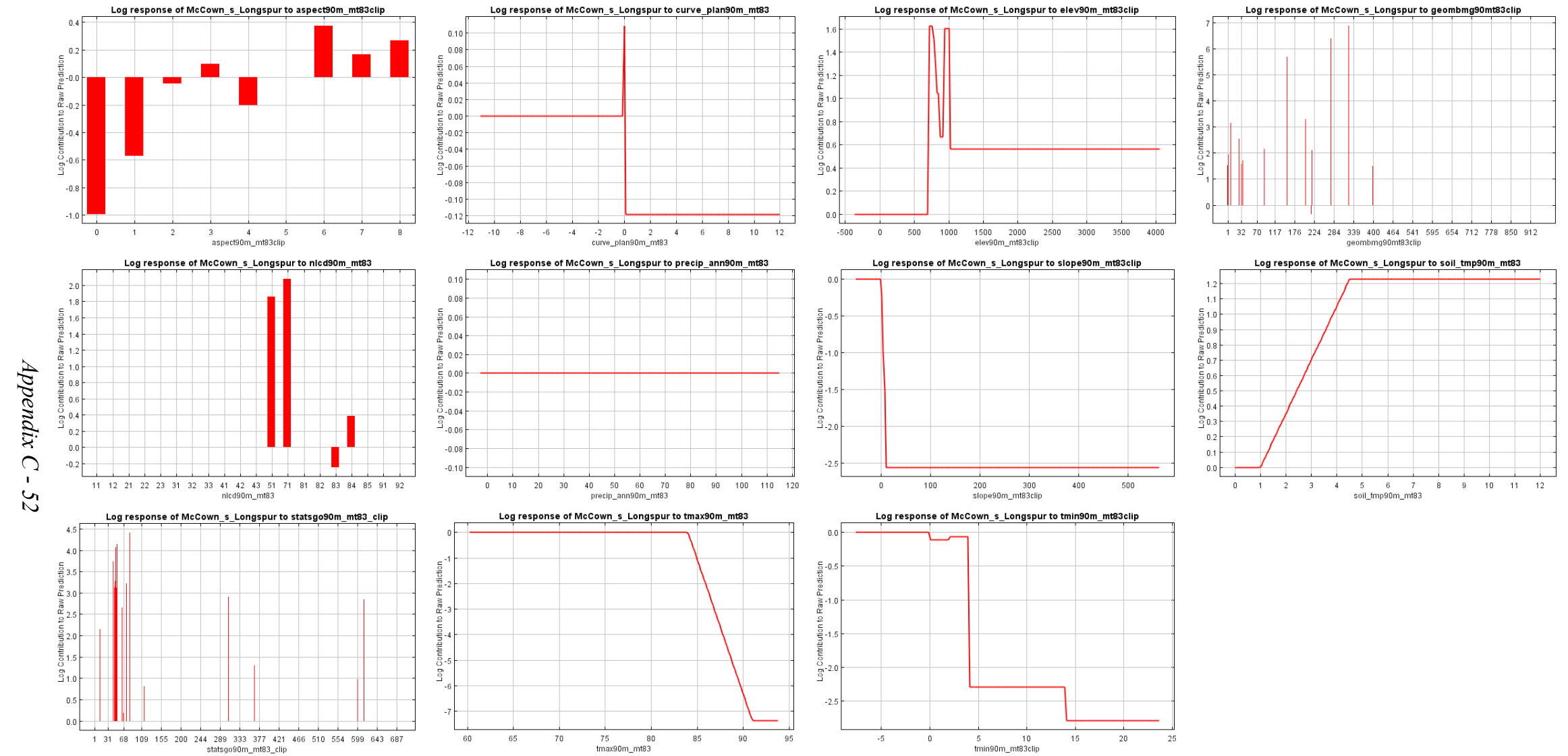

Figure C45. Response curves for individual environmental variables showing how the logistic prediction changes as each environmental variable is varied while all other environmental variables are held constant at their average sample values. The value on the $y$-axis is predicted probability of suitable conditions as given by the logistic formula $P(x)$ $=\exp (c 1 * f 1(x)+c 2 * f 2(x)+c 3 * f 3(x) \ldots) / Z$. Note that if any of the environmental variables are correlated, the marginal response curves can be misleading (e.g., two highly correlated variables with opposite response curves could effectively cancel each other out). Value definitions and/or links to metadata containing these definitions can be found in the Descriptions of Environmental Input Layers section of the appendix above. 


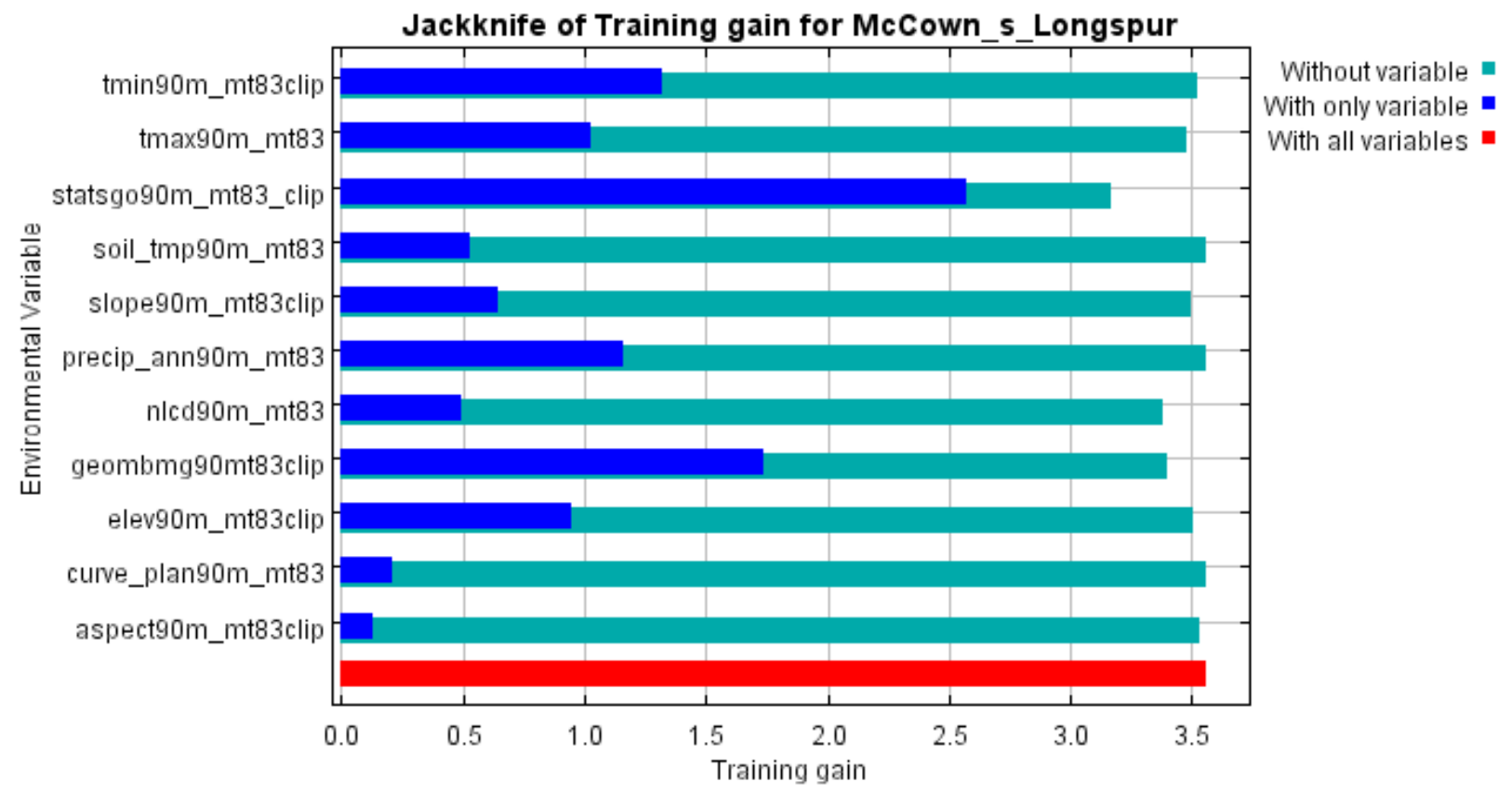

Figure C46. Jackknife chart showing the relative importance of environmental variables as a function of the change in "gain" (the log of the number of grid cells minus the average of the negative log probabilities of the sample locations) resulting from the exclusion or sole inclusion of the environmental variable in the model. Variables with the highest training gain resulting from sole inclusion of those variables (dark blue bars) are the best individual variables at describing suitable habitat for the species. Variables with the greatest reduction in training gain resulting from their exclusion (light blue bars) contain information on the species habitat use that is not present in other variables. The red bar indicates the maximum gain achieved with inclusion of all variables. 


\section{Chestnut-collared Longspur (Calcarius ornatus)}

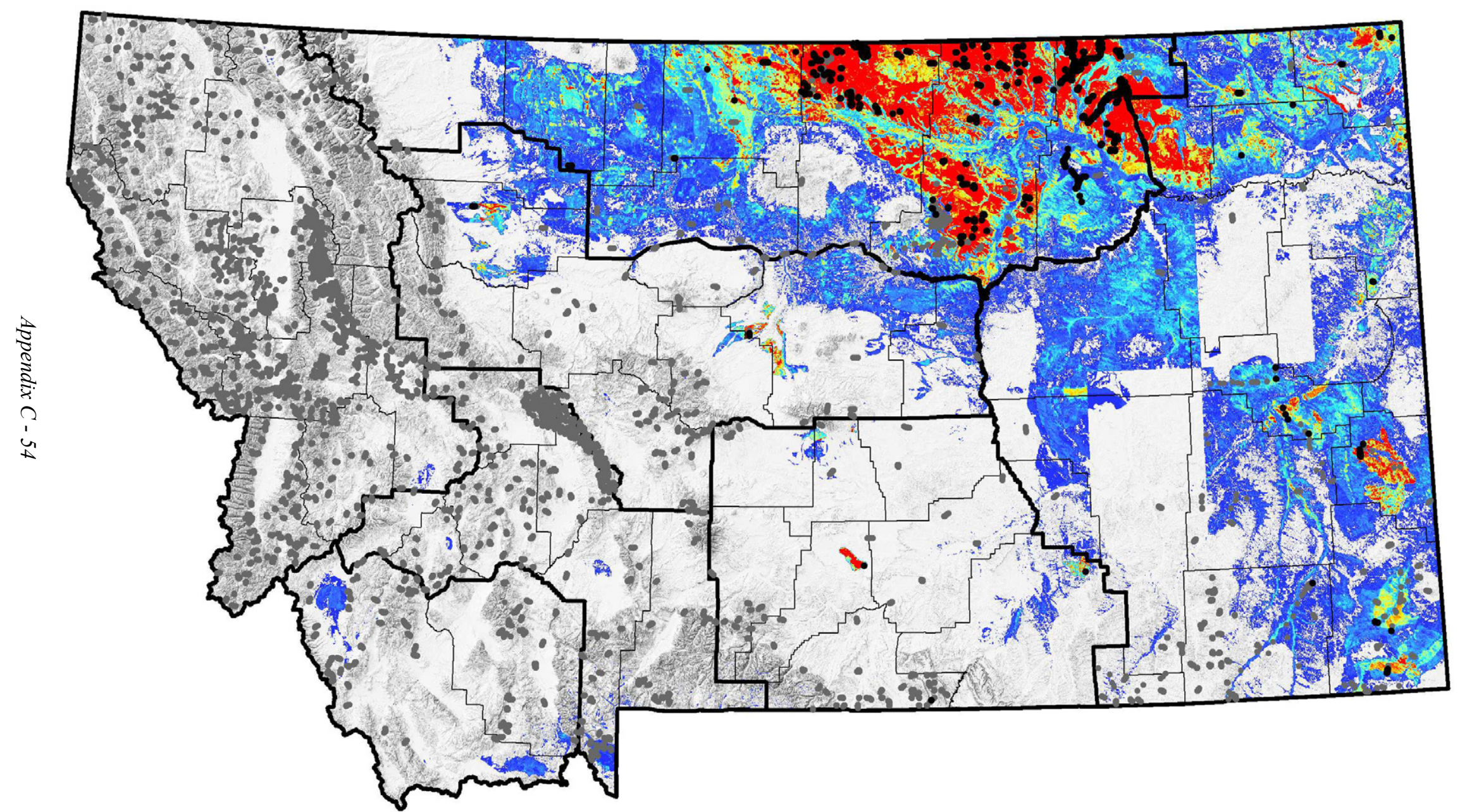

Figure C47. The hot-to-cold color map indicates the suitability of each grid cell as a function of the environmental variables at that grid cell. Hotter colors indicate areas that are predicted to have more suitable habitat for the species. Black dots are positive data used to build the model. Gray dots are locations where a survey capable of detecting the species has been performed. A shaded relief map, BLM Field Office boundaries, and county lines are included for reference. 


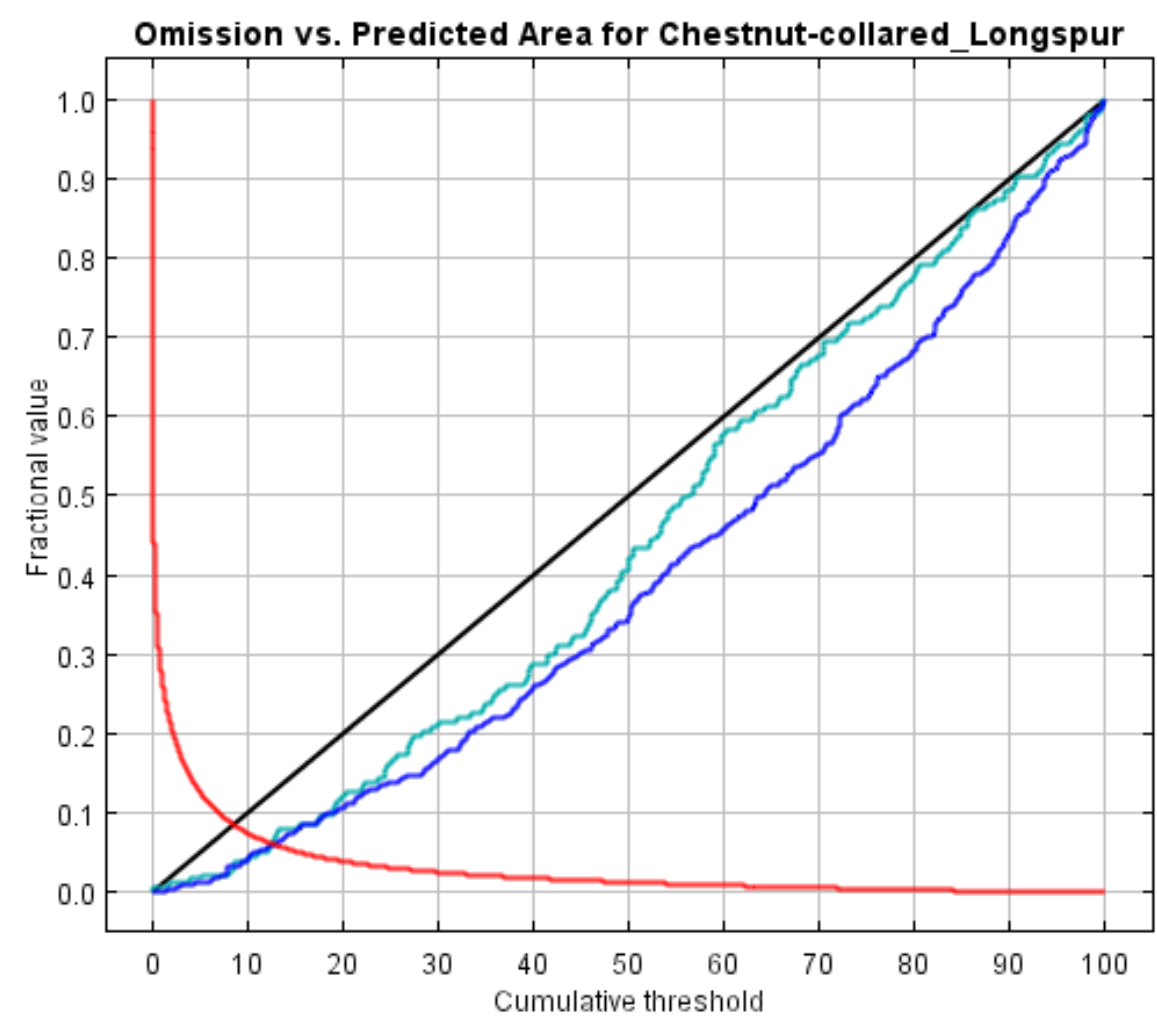

Fraction of background predicted Omission on training samples Omission on test samples Predicted omission

Figure C48. An evaluation of omission error rates for training (dark blue line) and test (light blue line) data as a function of the cumulative threshold and overall predicted area. The red line indicates the overall fraction of the map area fitting each value of the cumulative threshold. The black line is the predicted omission rate for each cumulative threshold. 


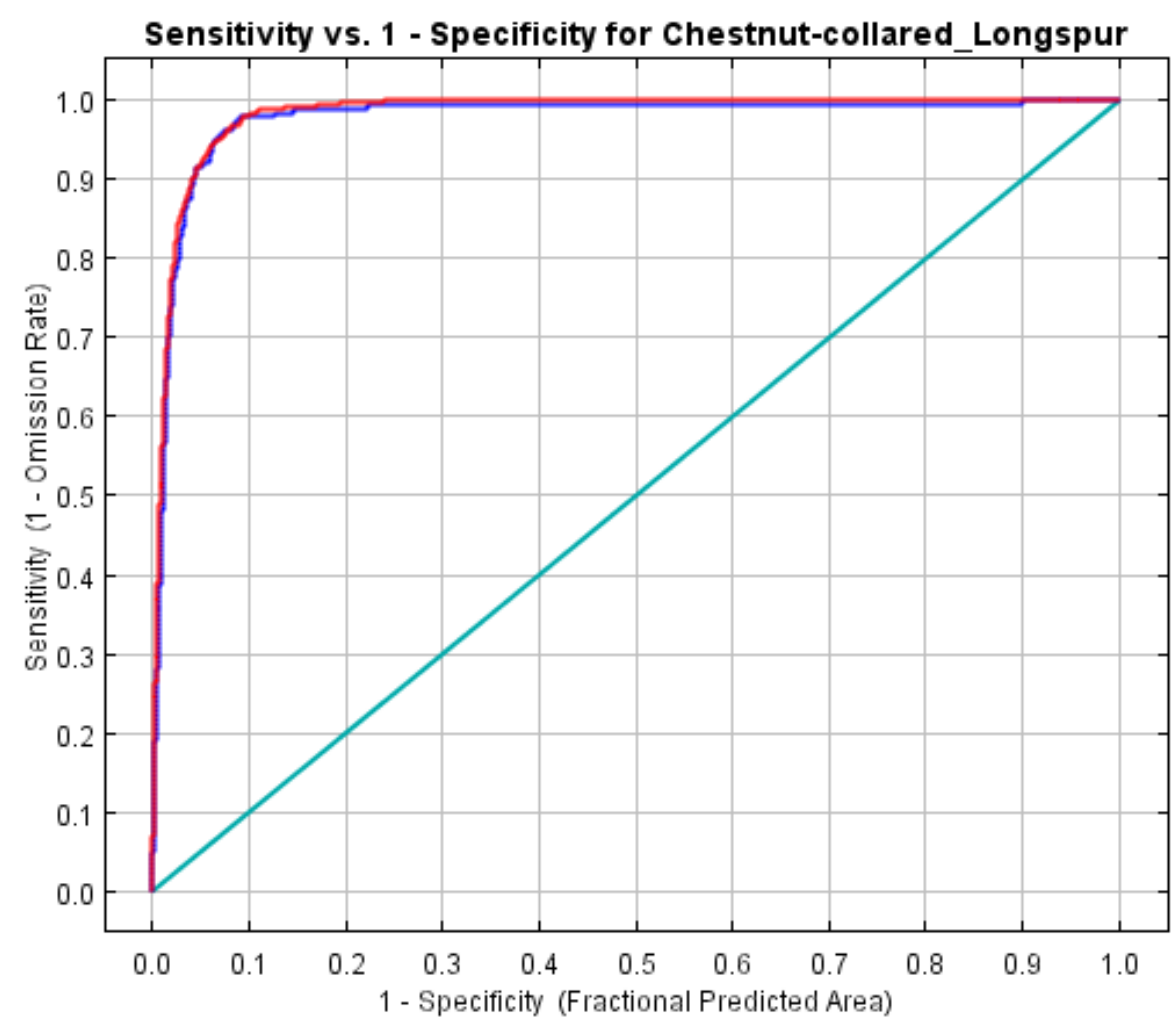

Training data $(\mathrm{AUC}=0.983)$.

Test data $(A \cup C=0.976)$.

Random Prediction $(\mathrm{AUC}=0.5)$

Figure C49. Receiver Operating Characteristic (ROC) curve evaluating the overall predictive power of the model with the Area Under the Curve (AUC). The AUC value indicates that when two random locations are chosen the model has that probability of assigning a higher cumulative threshold value to the location with more suitable habitat. The light blue line indicates how a neutral or random model would perform (i.e., it only has a 50\% probability of assigning a higher cumulative threshold value to a random location with more suitable habitat than a random location with less suitable habitat). The further toward the top left of the graph the training (red) and test (blue) data lines are, the better the model is at predicting the presences contained in the training data. Sensitivity (plotted on the y-axis) is the proportion of positive locations that were correctly classified by the model. Sensitivity is also known as the true positive rate and can be thought of as the degree of absence of omission errors. Specificity is the proportion of random locations chosen from the background (these pseudo-absences are used instead of true negative locations) that were correctly classified by the model as negative. One minus the Specificity (plotted on the $x$-axis) is known as the false positive rate and represents the commission error rate. 

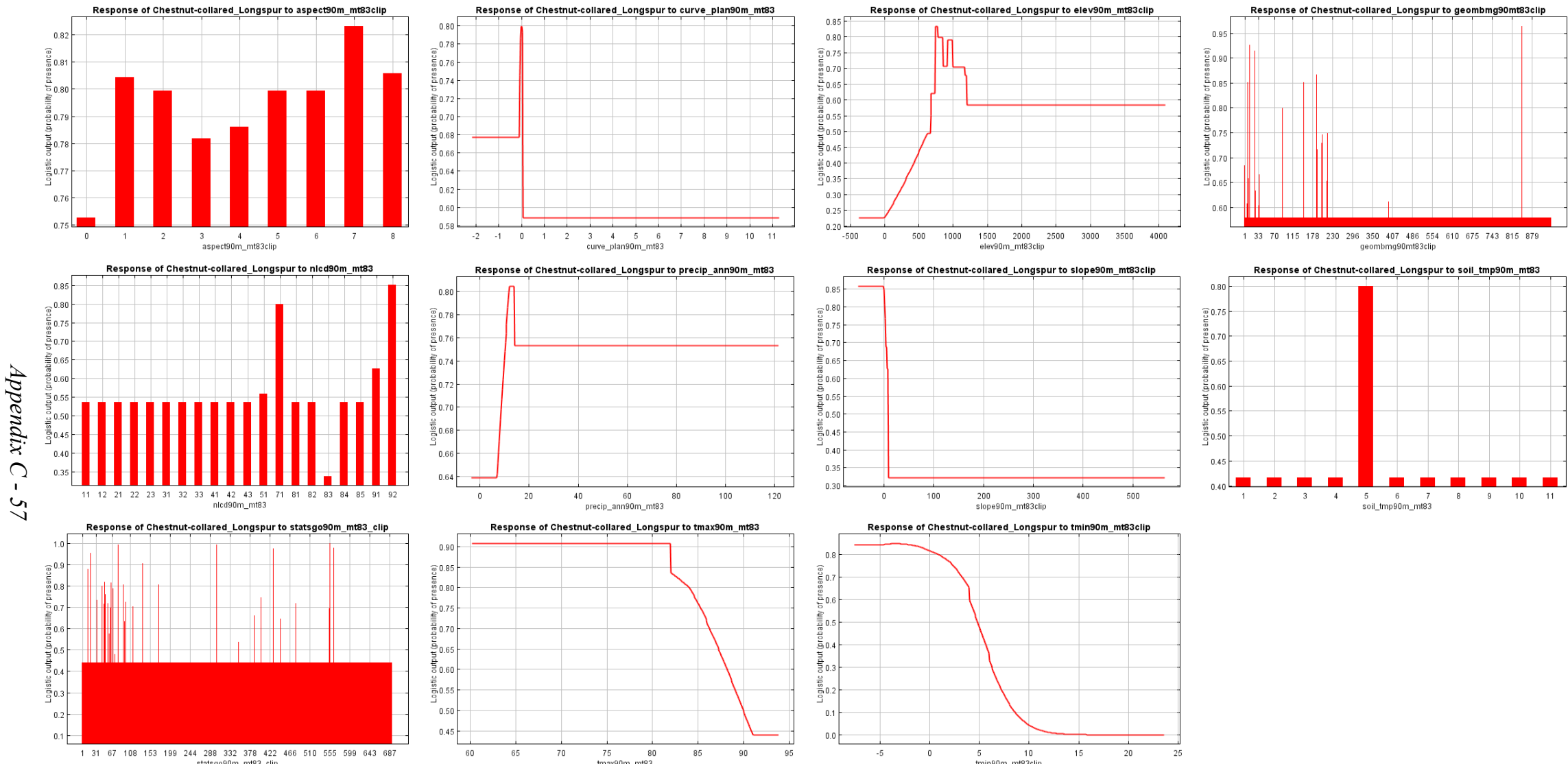

Figure C50. Response curves for individual environmental variables showing how the logistic prediction changes as each environmental variable is varied while all other environmental variables are held constant at their average sample values. The value on the $y$-axis is predicted probability of suitable conditions as given by the logistic formula $P(x)$ $=\exp (c 1 * f 1(x)+c 2 * f 2(x)+c 3 * f 3(x) \ldots) / Z$. Note that if any of the environmental variables are correlated, the marginal response curves can be misleading (e.g., two highly correlated variables with opposite response curves could effectively cancel each other out). Value definitions and/or links to metadata containing these definitions can be found in the Descriptions of Environmental Input Layers section of the appendix above. 


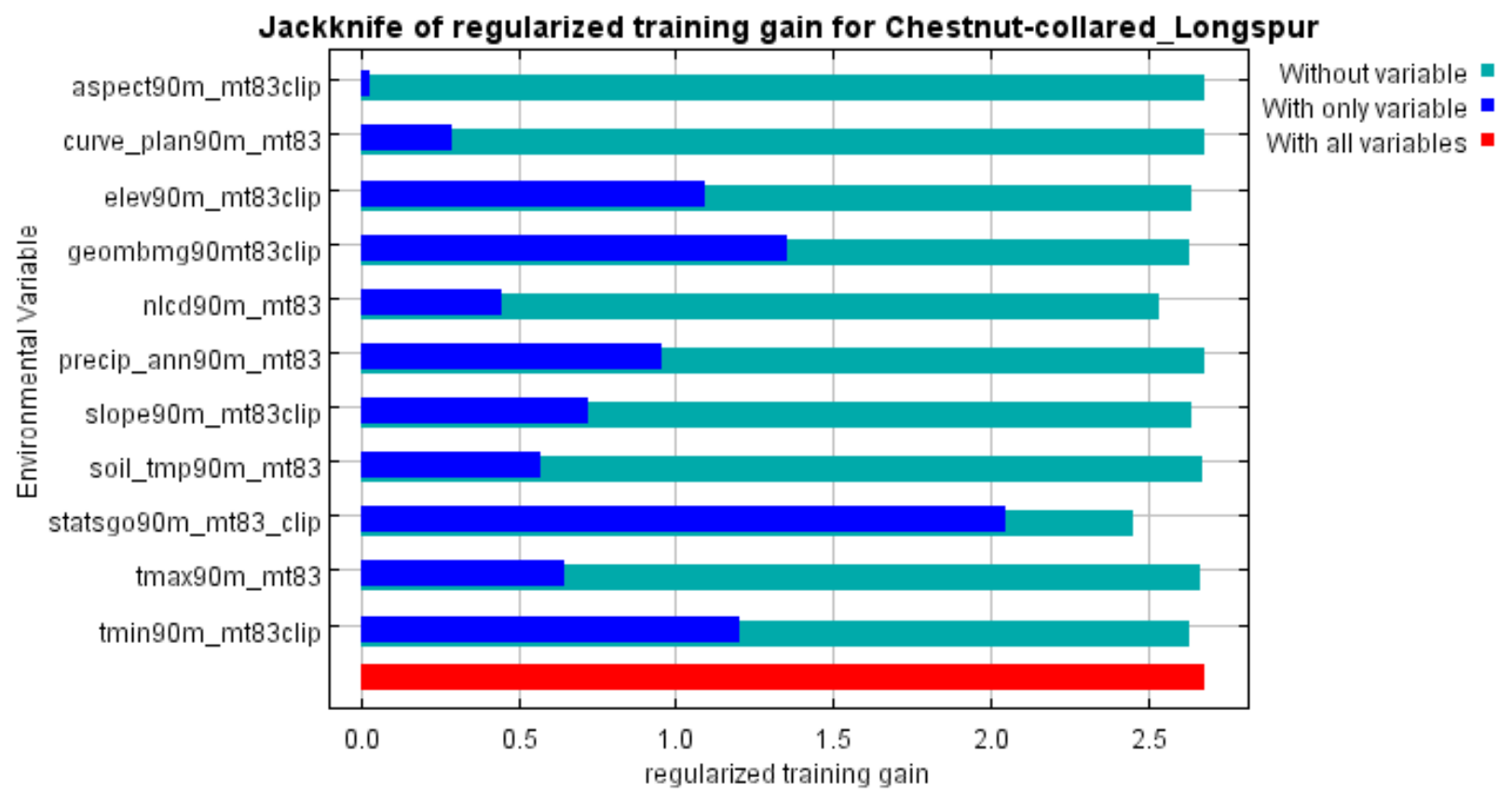

Figure C51. Jackknife chart showing the relative importance of environmental variables as a function of the change in "gain" (the log of the number of grid cells minus the average of the negative log probabilities of the sample locations) resulting from the exclusion or sole inclusion of the environmental variable in the model. Variables with the highest training gain resulting from sole inclusion of those variables (dark blue bars) are the best individual variables at describing suitable habitat for the species. Variables with the greatest reduction in training gain resulting from their exclusion (light blue bars) contain information on the species habitat use that is not present in other variables. The red bar indicates the maximum gain achieved with inclusion of all variables. 


\section{Bobolink (Dolichonyx oryzivorus)}

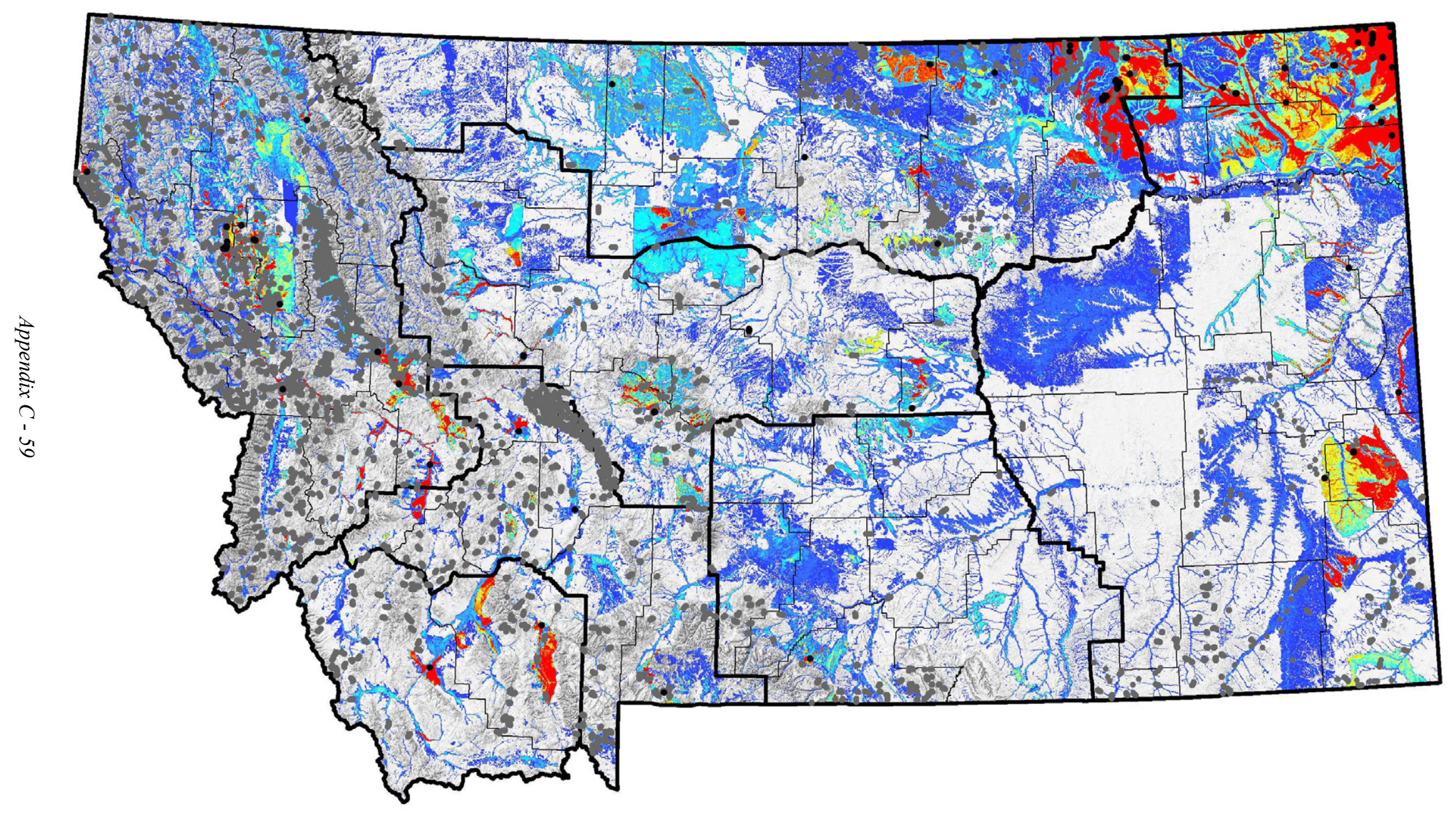

Figure C52. The hot-to-cold color map indicates the suitability of each grid cell as a function of the environmental variables at that grid cell. Hotter colors indicate areas that are predicted to have more suitable habitat for the species. Black dots are positive data used to build the model. Gray dots are locations where a survey capable of detecting the species has been performed. A shaded relief map, BLM Field Office boundaries, and county lines are included for reference. 


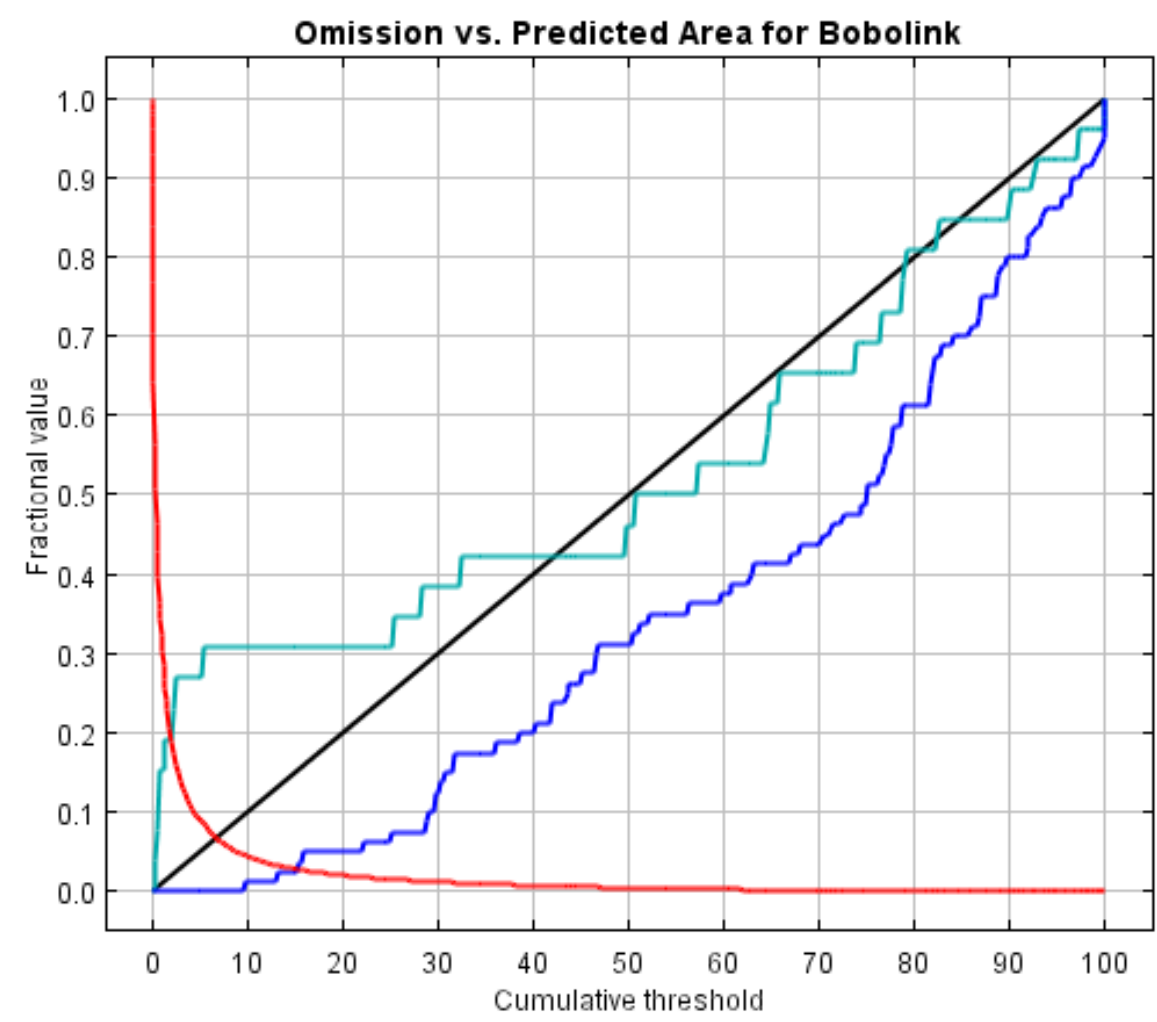

Fraction of background predicted Omission on training samples $\mathbf{~}$ Omission on test samples Predicted omission

Figure C53. An evaluation of omission error rates for training (dark blue line) and test (light blue line) data as a function of the cumulative threshold and overall predicted area. The red line indicates the overall fraction of the map area fitting each value of the cumulative threshold. The black line is the predicted omission rate for each cumulative threshold. 


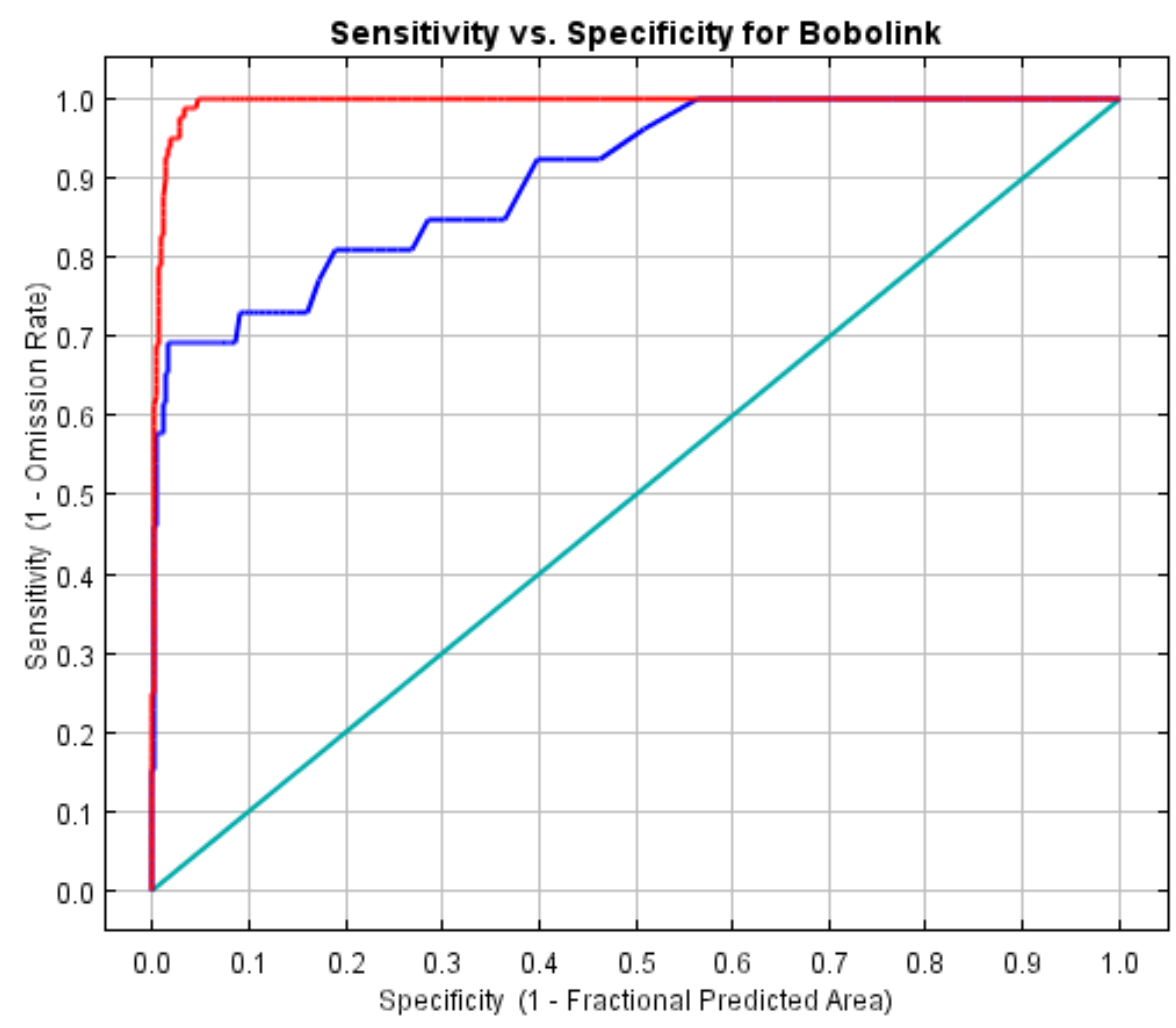

Training data $(\mathrm{AUC}=0.995)$.

Test data $(A \cup C=0.901)$ -

Random Prediction $(\mathrm{AUC}=0.5)$

Figure C54. Receiver Operating Characteristic (ROC) curve evaluating the overall predictive power of the model with the Area Under the Curve (AUC). The AUC value indicates that when two random locations are chosen the model has that probability of assigning a higher cumulative threshold value to the location with more suitable habitat. The light blue line indicates how a neutral or random model would perform (i.e., it only has a 50\% probability of assigning a higher cumulative threshold value to a random location with more suitable habitat than a random location with less suitable habitat). The further toward the top left of the graph the training (red) and test (blue) data lines are, the better the model is at predicting the presences contained in the training data. Sensitivity (plotted on the y-axis) is the proportion of positive locations that were correctly classified by the model. Sensitivity is also known as the true positive rate and can be thought of as the degree of absence of omission errors. Specificity is the proportion of random locations chosen from the background (these pseudo-absences are used instead of true negative locations) that were correctly classified by the model as negative. One minus the Specificity (plotted on the x-axis) is known as the false positive rate and represents the commission error rate. 

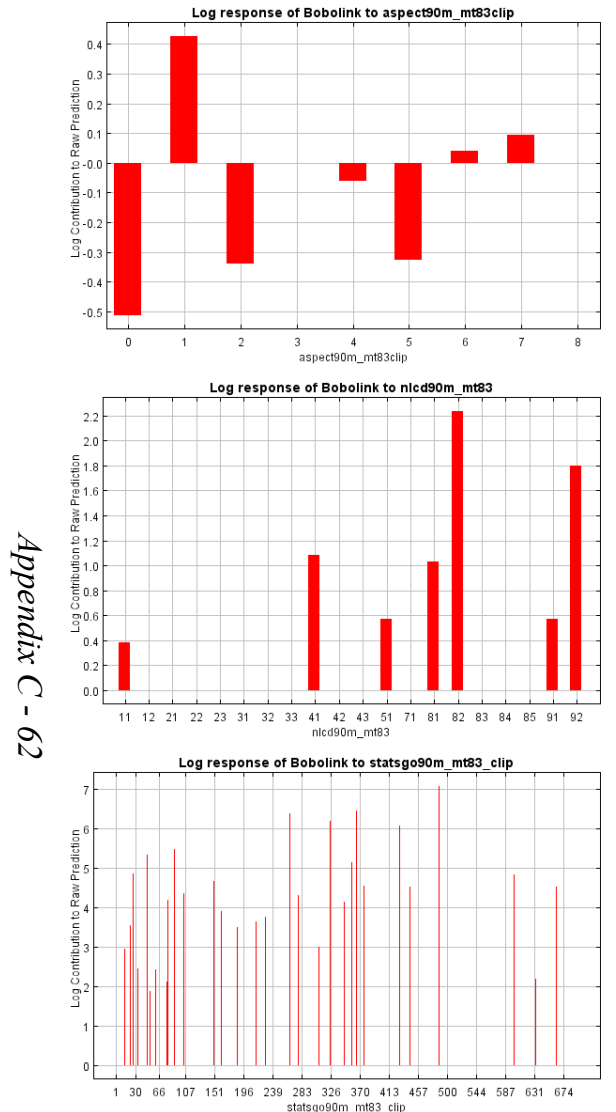

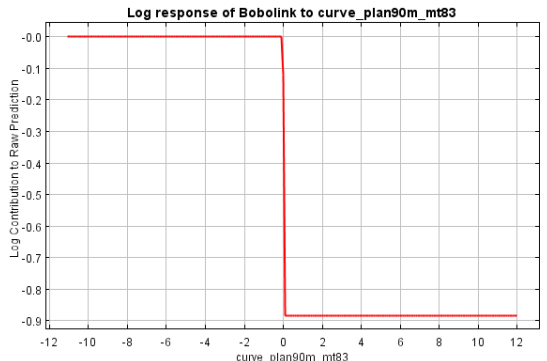

Log response of Bobolink to precip_annsom m mt3
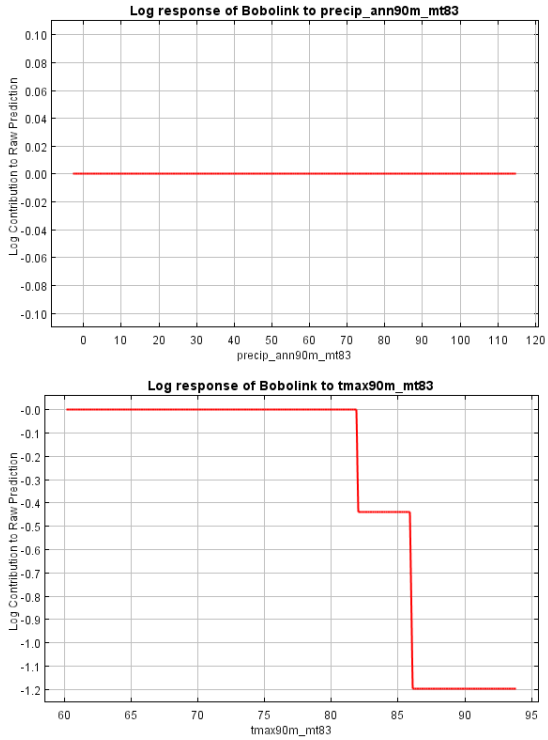

Log response of Bobolink to ele v9om_mmb3clip

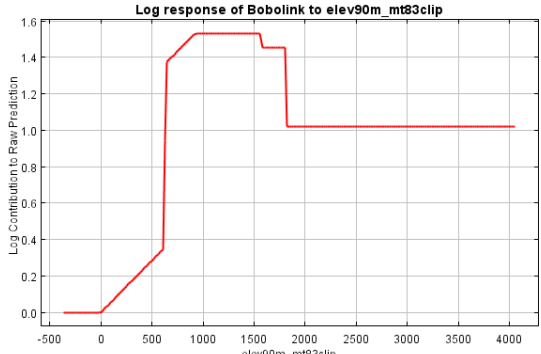

Log response of Bobolink to slope90m_mmb3clip

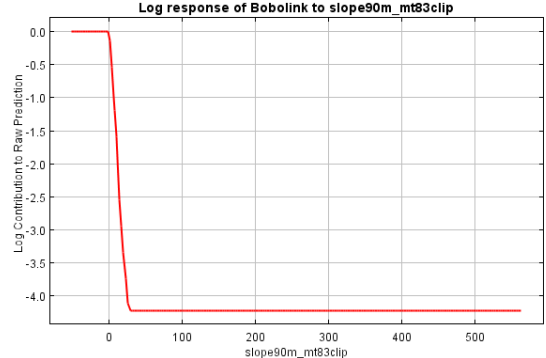

f Bobolink to tmingom mtracclip

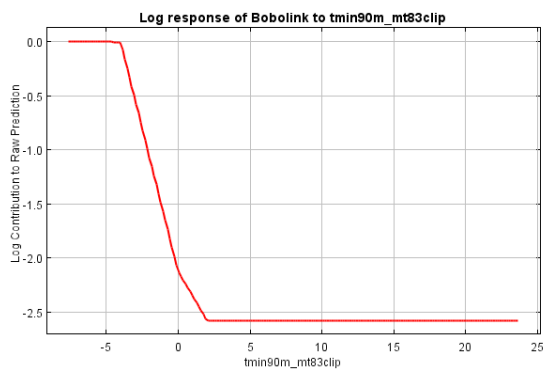

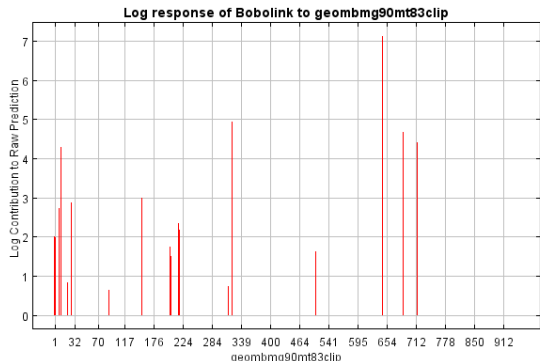

Log response of Bobolink to soil_tmp90m_mt83

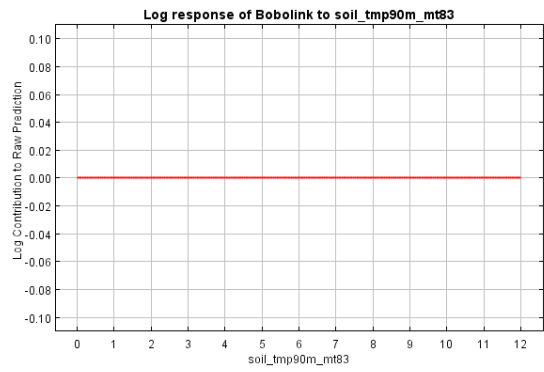

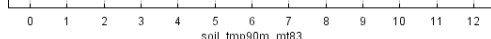

Figure C55. Response curves for individual environmental variables showing how the logistic prediction changes as each environmental variable is varied while all other environmental variables are held constant at their average sample values. The value on the $y$-axis is predicted probability of suitable conditions as given by the logistic formula $P(x)$ $=\exp (c 1 * f 1(x)+c 2 * f 2(x)+c 3 * f 3(x) \ldots) / Z$. Note that if any of the environmental variables are correlated, the marginal response curves can be misleading (e.g., two highly correlated variables with opposite response curves could effectively cancel each other out). Value definitions and/or links to metadata containing these definitions can be found in the Descriptions of Environmental Input Layers section of the appendix above. 


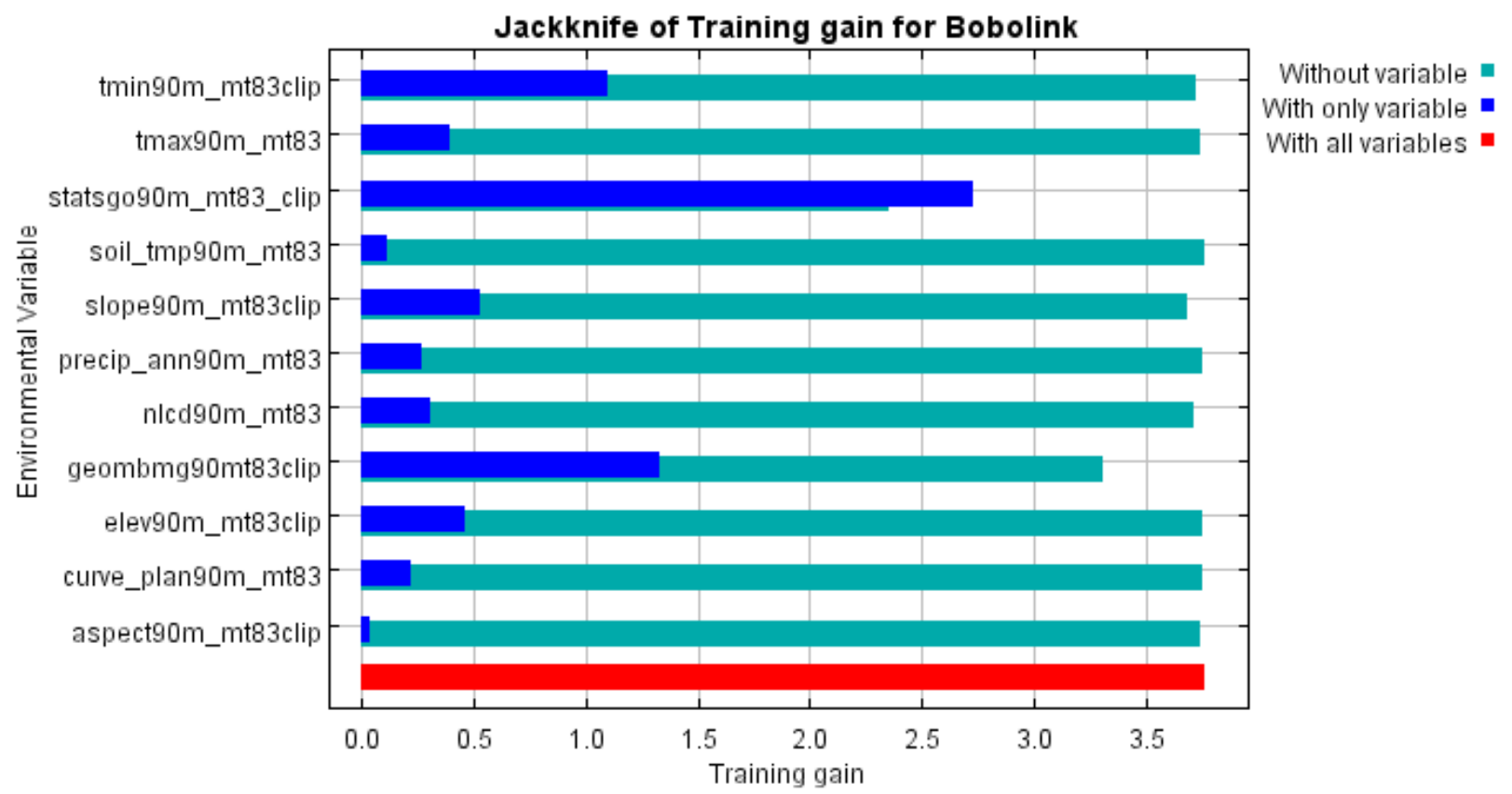

Figure C56. Jackknife chart showing the relative importance of environmental variables as a function of the change in "gain" (the log of the number of grid cells minus the average of the negative log probabilities of the sample locations) resulting from the exclusion or sole inclusion of the environmental variable in the model. Variables with the highest training gain resulting from sole inclusion of those variables (dark blue bars) are the best individual variables at describing suitable habitat for the species. Variables with the greatest reduction in training gain resulting from their exclusion (light blue bars) contain information on the species habitat use that is not present in other variables. The red bar indicates the maximum gain achieved with inclusion of all variables. 